\author{
UNIVERSIDADE DE SÃO PAULO \\ FACULDADE DE SAÚDE PÚBLICA
}

\title{
DA AGENDA AMBIENTAL À VIGILÂNCIA AMBIENTAL: UM PERCURSO HISTÓRICO E BIOPOLÍTICO
}

\author{
RODRIGO ROMÃO
}

Tese apresentada ao Programa de Pós-Graduação em Saúde Pública da Faculdade de Saúde Pública da Universidade de São Paulo para obtenção do título de Doutor em Ciências.

Área de Concentração: Serviços de Saúde Pública

Orientadora: Prof. ${ }^{a}$ Dr. ${ }^{a}$ Maria Cristina da Costa Marques

São Paulo

2019 


\title{
DA AGENDA AMBIENTAL À VIGILÂNCIA AMBIENTAL: UM PERCURSO HISTÓRICO E BIOPOLÍTICO
}

\author{
RODRIGO ROMÃO
}
Tese apresentada ao Programa de Pós-Graduação em Saúde Pública da Faculdade de Saúde Pública da Universidade de São Paulo para obtenção do título de Doutor em Ciências.

Área de Concentração: Serviços de Saúde Pública

Orientadora: Prof. ${ }^{\text {a }}$ Dr. ${ }^{a}$ Maria Cristina da Costa Marques

\section{Versão Original}

São Paulo

2019 
Autorizo a reprodução e divulgação total ou parcial deste trabalho, por qualquer meio convencional ou eletrônico, para fins de estudo e pesquisa, desde que citada a fonte.

Catalogação da Publicação

Ficha elaborada pelo Sistema de Geração Automática a partir de dados fornecidos pelo(a) autor(a) Bibliotecária da FSP/USP: Maria do Carmo Alvarez - CRB-8/4359

Romão, Rodrigo

Da Agenda Ambiental à Vigilância Ambiental: um percurso histórico e biopolítico / Rodrigo Romão; orientadora Maria Cristina da Costa Marques. -- São Paulo, 2019.

$129 \mathrm{p}$.

Tese (Doutorado) -- Faculdade de Saúde Pública da Universidade de São Paulo, 2019.

1. Vigilância Ambiental. 2. Genealogia. 3. Saúde Pública. I. da Costa Marques, Maria Cristina, orient. II. Título. 
Nome: ROMÃO, Rodrigo

Título: Da Agenda ambiental à Vigilância Ambiental: um percurso histórico e biopolítico

Tese apresentada ao Programa de Pós-Graduação em Saúde Pública da Faculdade de Saúde Pública da Universidade de São Paulo para obtenção do título de Doutor em Ciências.

Aprovado em:

Banca Examinadora

Prof. Dr.

Instituição:

Julgamento:

Prof. Dr.

Instituição:

Julgamento:

Prof. Dr.

Instituição:

Julgamento: 


\section{Dedicatória}

Ao meu amado pai Edgar Romão (in memoriam). 


\section{AGRADECIMENTOS}

Em primeiríssimo lugar aos meus pais, para quem tudo devo, e à minha esposa e meu filho: Kerley Cristiane Victorino Romão e Pedro Victorino Romão - motivações eternas.

À minha caríssima Orientadora, Prof. a Dr. a Maria Cristina da Costa Marques, por acreditar no meu trabalho e me conduzir. 


\section{Lista de Abreviaturas e Siglas}

ABRASCO (Associação Brasileira de Saúde Coletiva)

A.C. (antes de Cristo)

BVMS (Biblioteca Virtual em Saúde)

CETESB (Companhia Ambiental do Estado de São Paulo)

CGVAM (Coordenação Geral de Vigilância em Saúde Ambiental)

CGST (Coordenação Geral de Saúde do Trabalhador)

COFAB (Coordenação de Vigilância de Fatores de Risco Biológicos)

COPASAD (Conferência Pan-Americana sobre a Saúde e Ambiente no Desenvolvimento Humano Sustentável)

CONAB (Coordenação de Vigilância de Fatores de Risco Não Biológicos)

CSN (Companhia Siderúrgica Nacional)

D.O.U. (Diário Oficial da União)

DATAPREV (Empresa de Tecnologia e Informações da Previdência Social)

DATASUS (Departamento de Informática do SUS)

DSAST (Departamento de Vigilância em Saúde Ambiental e Saúde do Trabalhador)

E.U.A (Estados Unidos da América)

FEEMA (Fundação Estadual de Engenharia do Meio Ambiente)

FPEEEA (força motriz - pressão - estado - exposição - efeito - ação)

FUNASA (Fundação Nacional de Saúde)

GAL (Gerenciador de Ambiente Laboratorial)

GO (Estado de Goiás)

LTDA (Limitada)

MG (Estado de Minas Gerais)

MMA (Ministério do Meio Ambiente)

MTST (Movimento dos Trabalhadores Sem Teto)

OMS (Organização Mundial de Saúde)

ONU (Organização das Nações Unidas)

PCB (Polychlorinated biphenyls)

pH (Potencial hidrogênionico) 
PIB (Produto Interno Bruto)

PNVS (Política Nacional de Vigilância em Saúde)

POP (Poluente Orgânico Persistente)

PUBMED (US National Library of Medicine National Institutes of Health)

QBRN (Químico, Biológico, Radiológico e Nuclear)

SCIELO (Scientific Eletronic Library Online)

SEADE (Fundação Sistema Estadual de Análise de Dados)

SEMA (Secretaria Especial de Meio Ambiente)

SINVAS (Sistema Nacional de Vigilância Ambiental em Saúde)

SP (Estado de São Paulo)

SVS (Secretaria de Vigilância em Saúde)

VIGIAGUA (Programa Nacional de Vigilância da Qualidade da Água para Consumo Humano)

VIGIAR (Vigilância em Saúde de Populações Expostas a Poluição Atmosférica)

VIGIDESASTRE (Vigilância em Saúde Ambiental dos Riscos Associados aos

Desastres)

VIGIFIS (Vigilância em Saúde Ambiental Associada aos Fatores Físicos)

VIGIPEQ (Vigilância em Saúde de Populações Expostas a Contaminantes Químicos)

VIGIQUIM (Vigilância em Saúde Ambiental relacionada a Populações Expostas a

Substancias Químicas)

VIGISOLO (Vigilância em Saúde de Populações Expostas a Áreas Contaminadas)

VIGISUS (Modernização do Sistema Nacional de Vigilância em Saúde) 


\section{Lista de Figuras}

Figura 1 - Número absoluto de estabelecimentos industriais segundo Estado da Federação, Brasil, 2015. P. 67.

Figura 2 - Organograma da Coordenação Geral de Vigilância em Saúde Ambiental, 2017. P.99 


\section{RESUMO}

ROMÃO, Rodrigo. Da Agenda ambiental à Vigilância Ambiental: um percurso histórico e biopolítico. 2018. 129 f. Tese (Doutorado em Serviços de Saúde Pública) Faculdade de Saúde Pública, Universidade de São Paulo, São Paulo, 2019.

A presente tese se propõe a traçar uma genealogia da Vigilância Ambiental no Brasil. Partindo de um conjunto de chaves interpretativas da obra do filósofo Michel Foucault, congregamos um amplo leque de fontes documentais para compreender os primeiros sinais de uma incipiente medicina preventiva e sua agenda eminentemente ambiental, ainda em um Brasil pré-imperial, e observamos suas transformações em paridade com o desenvolvimento de nossa sociedade - buscando aí encontrar o mote biopolítico, dado que a construção da nação exigia medidas sanitárias que garantissem a saúde da população, ainda que não necessariamente por questões humanitárias. Acompanhamos a transição da agenda ambiental na saúde pública, que leva em conta os impactos do meio ambiente na existência humana para o movimento reverso, quando nos damos conta de que a humanidade está provocando danos possivelmente irreversíveis ao planeta - e como essa nova fase tem afetado nossa saúde. De maneira crítica e reflexiva, discutimos a formação e a dimensão biopolítica da Vigilância Ambiental na atualidade, dispondo de maiores e melhores recursos tecnológicos, mas atuando em uma governamentalidade neoliberal de redução de direitos - que afetam, inclusive, o direito à saúde.

Palavras-chave: Genealogia, governamentalidade; biopolítica; Vigilância Ambiental; Saúde Pública. 


\begin{abstract}
ROMÃO, Rodrigo. From the Environmental Agenda to Environmental Surveillance: a historical and biopolitical path. 2018. $129 \mathrm{f}$. Thesis (Doctorate in Public Health Services) - Faculty of Public Health, University of São Paulo, São Paulo, 2019.

This thesis aims to trace the genealogy of Enviromental Surveillance in Brazil. From the standpoint a set of interpretative concepts of the philosopher Michel Foucault, we convey a vast array of documental sources to comprehend the first signs of an incipient preventive care and its respectable environmental agenda, still in a pre-imperial Brazil, and we observe its transformations parallel to the development of our society - aiming to find the biopolitical mote, given that the creation of the nation required sanitation methods that could guarantee the health of the population, even though not by strictly humanitarian reasons. We follow the transtition of the environmental agenda in our public health, which takes into consideration the impact of the environment in the human existence to the reverse movement, when we come to the realization that humanity has been causing possibly irreversible damage to the environment - and due to this also affecting our health. In a critic and self-reflecting way, we discuss the formation and the dimension of biopolitics of the Enviromental Surveillance in current day society, having access to a vast array of newer and better technological resources, but acting in a neoliberal governmentality of deprivation of rights, that also affect the right to health.
\end{abstract}

Key-words: Genealogy, governmentality, biopolitics, Environmental Surveillance, Public Health. 


\section{SUMÁRIO}

Introdução e objetivo 13

Capítulo $1 \quad 18$

Percurso Metodológico $\quad 18$

Capítulo $2 \quad 28$

Chaves Foucaultianas e a centralidade do risco 28

Genealogia não é gênese 28

2.1 - Governamentalidade $\quad 30$

2.2 - Biopolítica/biopoder $\quad 38$

2.3 - A centralidade do Risco $\quad 41$

Capítulo 3

Controlar para progredir: estratégias biopolíticas no Brasil 45

Capítulo $4 \quad 61$

Nosso desenvolvimento insustentável 61

4.1 Sobre os passivos que herdamos e/ou ainda produzimos $\quad 69$

Capítulo 5

O surgimento da Vigilância em Saúde Ambiental: $\quad 78$

demonstrando uma genealogia $\quad 78$

$\begin{array}{ll}\text { Capítulo } 7 & 114\end{array}$

Conclusão e avaliação do caminho percorrido $\quad 114$

Referências Bibliográficas $\quad 120$

Anexos 129

Currículo Lattes 


\section{Introdução e objetivo}

Há muito se sabe que os seres humanos enfrentam estressores ambientais das mais diversas naturezas - e conhecemos, igualmente, a importância da adaptação aos mesmos enquanto elementos essenciais ao desenvolvimento civilizatório. Muito diferente, no entanto, é a situação dos estressores ambientais gerados pela modernização do modo de produção capitalista e seus significativos impactos nos diversos ecossistemas e, em particular, na ecologia humana. Viver nesta nova época - denominada por alguns como antropoceno, em alusão a um período ímpar na história natural do planeta - traz em si a necessidade de elaborar novas estratégias de proteção, controle e monitoramento epidemiológico e ambiental.

Apesar de consistir ainda um objeto de disputa, a noção de antropoceno apoia a perspectiva que adotaremos no presente trabalho, nos seguintes termos:

\footnotetext{
Estamos vivendo no limiar de uma nova época. Muitos geólogos e especialistas em estratigrafia, e de outras áreas, com o argumento de que a ação humana tem mudado enormemente o funcionamento e os fluxos do planeta, afirmam que entramos em uma nova época geológica, o Antropoceno. E suas marcas são bastante visíveis em todos os lugares por onde a espécie humana transita ou já esteve. Poluição de rios e oceanos por microplásticos e um sem fim de substâncias químicas, a alteração nos fluxos de nitrogênio pelo uso extensivo de fertilizantes na agricultura e, principalmente, as mudanças climáticas discutidas nas altas esferas da política mundial são algumas evidências de uma "época dos humanos". (RODRIGUES, 2017 p.19).
}

Podemos dizer que existe razoável compreensão quanto ao fato de que "a poluição e a falta de saneamento afetam a saúde"; no entanto, transformar esses problemas em tema de relevância para intervenção, superando o modelo medicalizante, permanece algo que cativa antes intenções do que propriamente enseja o desenvolvimento de ações - e tem conquistado adesões relativas. Há muito ultrapassamos o local e lidamos hoje com o global, de modo que o mote "think globally, act locally" já é um lugar comum. No universo da saúde ambiental, nosso problema é sistêmico e a importância do sucesso das estratégias de políticas públicas transcende o local e incide nos níveis regional, nacional e global. 
Ribeiro (2014) lembra:

Instituições argumentam que, nesta sociedade moderna, de fronteiras fluidas, transportes e economias globais, competição por recursos naturais e poluição transfronteiriça, toda saúde ambiental é global. E citam exemplos, como chumbo em brinquedos produzidos em um país e vendidos em quase todo mundo, alimentos produzidos e colhidos em alguns locais e servidos em mesas ao redor do globo, e a poluição gerada em um lugar que se dispersa por ar e água para locais distantes, com consequências inesperadas. (RIBEIRO, 2014 p.39-40)

O advento das cidades modernas e dos modos de produção desenvolvidos com a revolução industrial trouxeram desafios que foram se traduzindo em tecnologias de saúde pública para a gestão da população. Aspectos dessas tecnologias se traduzem como monitoramento, controle e vigilância de agentes e situações sabidamente disparadores de doenças e agravos à saúde. Um tipo de vigilância "com ênfase na promoção e na prevenção de riscos" (AUGUSTO, 2003) é um dos resultados culminantes. Porém, essas práticas têm uma historicidade no mundo e no Brasil e no presente estudo nos debruçaremos sobre a díade saúde e meio ambiente até a sua expressão como estratégia biopolítica de vigilância de agravos e doenças relacionadas ao meio ambiente no Brasil.

Diretamente, pretendemos descobrir como se dá a inserção da agenda ambiental e da vigilância em saúde ambiental no seio das diversas Vigilâncias no campo da saúde pública, hoje incluídas sob o "guarda-chuva" denominado Vigilância em Saúde.

Tendo suas bases fundamentadas nos conceitos e práticas de isolamento e quarentena (utilizados desde a idade média) até o de cordão sanitário aplicado às cidades e bairros; também muito vinculado ao poder de polícia, restrição e punição; o conceito de vigilância em saúde pública passou por intenso desenvolvimento teórico e prático adquirindo denominações específicas como vigilância epidemiológica, a partir de 1965, pela OMS, vigilância sanitária, ainda antes dessa data no Brasil, e se desdobrando em novas áreas tais como saúde do trabalhador e saúde ambiental após a criação do Sistema Único de Saúde e as primeiras formulações integrativas dessas áreas, notadamente a Vigilância da Saúde. Sumariamente, podemos dizer que o tema vem sendo construído há pelo menos 60 anos (WALDMAN, 1991 e TEIXEIRA, PAIM \& VILLASBOAS, 1998). Mais à frente, faremos referência a noção de Vigilância da 
Saúde, no entanto, desde já fica dito que a forma hoje institucionalizada e nominada em documentos e legislações é a Vigilância em Saúde.

Hoje, a Resolução no 588, de 12 de julho de 2018, relativa à Política Nacional de Vigilância em Saúde (PNVS), estabelece no parágrafo primeiro do seu artigo $2^{\circ}$ que:

\begin{abstract}
Entende-se por Vigilância em Saúde o processo contínuo e sistemático de coleta, consolidação, análise de dados e disseminação de informações sobre eventos relacionados à saúde, visando o planejamento e a implementação de medidas de saúde pública, incluindo a regulação, intervenção e atuação em condicionantes e determinantes de saúde, para a proteção e promoção da saúde da população, prevenção e controle de riscos, agravos e doenças (PNVS, 2018).
\end{abstract}

E no artigo $3^{\circ}$ ressalta:

\begin{abstract}
A PNVS compreende a articulação dos saberes, processos e práticas relacionados à vigilância epidemiológica, vigilância em saúde ambiental, vigilância em saúde do trabalhador e vigilância sanitária e alinha-se com o conjunto de políticas de saúde no âmbito do SUS, considerando a transversalidade das ações de vigilância em saúde sobre a determinação do processo saúde-doença (PNVS, 2018).
\end{abstract}

Como já mencionado, desejamos compreender a trajetória da agenda ambiental, suas circunstâncias mais marcantes, suas pretensões, a serviço de quem e para o bem de quem cada um desses campos foi se delineando no andar da história - sua genealogia, tal como Foucault a entendeu. No interior desta busca mais ampla encontraremos a emergência de uma área bem específica: a Vigilância em Saúde Ambiental - ou apenas Vigilância Ambiental.

Nosso pressuposto: algumas dessas áreas - e a agenda ambiental das "Vigilâncias" no campo da saúde pública, em particular - são formas de saber-poder instituídos pelo projeto burguês do Estado Brasileiro como estratégias biopolíticas de governo da população. Elas operacionalizam um mecanismo de poder capitalista, dominador, portanto, tendo a saúde pública como objeto de atuação e de luta. O meio ambiente vai tomando diferentes papéis e aos poucos gera um campo específico, como observamos acima, sob contextos históricos diferentes: o inicial na primeira república e o contemporâneo, pós movimento ambiental no Brasil e no mundo. 
A agenda ambiental vem sendo construída para atender necessidades de saúde, está claro, porém: quais? E, talvez mais importante, para quem? Breilh (2013) pontua que as necessidades de saúde podem ser abordadas a partir de pelo menos duas lógicas historicamente produzidas: primeiro, como um valor relativo, a depender de opções e sob a égide do mercado; e segundo, como um processo determinante de vida, como um direito inalienável (BREILH, 2013). Parece-nos necessário complementar que ainda existe a contraposição entre o 'de fato' e do 'de jure', já que no caso da saúde no Brasil convivemos com um bom texto legal e com carência de fatos concretos em muitas regiões.

O "emergir" da agenda ambiental se dá dentro de outro conceito que desejamos buscar em Foucault: trata-se da governamentalidade, entendendo por esta o conjunto de instituições, procedimentos, análises, cálculos e táticas que permitem exercer o poder sobre a população - uma tendência de desenvolvimento do governo, um processo através do qual o Estado governa uma população e com isso garante a boa reprodução de suas metas econômico-políticas (FOUCAULT, 2015a).

Uma governamentalidade viabiliza uma biopolítica, uma dada forma de gerir a vida de uma população. Dentro de uma dada governamentalidade dão-se diferentes genealogias, no nosso caso, historicamente, vão acontecendo e se estruturando, como mecanismo de governo de população, cada componente da chamada "Vigilância em Saúde", e mais, vão se estruturando as práticas de vigiar, controlar, monitorar, erradicar e analisar, entre outras, no campo da saúde pública.

Como veremos mais a frente, a genealogia de Foucault não é hierarquizada, formal, aliás ela pretende exatamente fugir dessa perspectiva e garantir que diversos acontecimentos possam tomar parte na constituição de um determinado fenômeno.

Ora, o ambiente, que sempre fez parte da teoria do processo saúde-doença, aos poucos vai recebendo um destaque específico, em especial quanto às possibilidades epidemiológicas de associação e correlação com dados ambientais. De maneira intrínseca e complexa, o ambiente importa para o biopoder, sofre com as governamentalidades e se transforma em campo de atuação. Aos poucos temos o 
meio ambiente sob o poder da polícia sanitária - ou ainda a relação da população com o ambiente, agora sob vigilância e sob a lógica neoliberal. A relação saúde e meio ambiente terminará apreendida pela lógica de mercado na própria política de Estado.

Eis as três chaves foucaultianas em que devemos nos aprofundar: a genealogia, a governamentalidade e a biopolítica na perspectiva das Vigilâncias - e a partir desse patamar observar a agenda ambiental que vai originando a área da Vigilância Ambiental. Traçar tal genealogia é o objetivo desta tese.

Cumpre ainda salientar que a opção pelo termo 'pressuposto' se dá em oposição ao termo 'hipótese' - em virtude de sua raiz positivista, com cunho demonstrativo lógico matemático, que não se aplica ao presente trabalho (MINAYO, 2014). 


\title{
Capítulo 1 \\ Percurso Metodológico
}

Para traçar nossa genealogia, foi realizado pesquisa teórica que abordou a construção da Vigilância Ambiental a partir da consulta de obras críticas e históricas, documentos, leis, artigos científicos e sítios eletrônicos. Os achados e as evidências coletadas nestas diversas fontes permitiram uma leitura interpretativa sob bases foucaultianas, sem excluir outras abordagens e perspectivas complementares. Vale ressaltar que a experiência prática do autor na área das Vigilâncias certamente teve efeito tanto no que tange a pontos de vista como em todo o percurso da pesquisa.

O objetivo foi elaborar uma genealogia que tratasse do nascimento da área em questão, onde o econômico se revelou prioritário ao bem-estar coletivo da população - e que tal bem-estar foi perseguido antes por razões econômicas do que propriamente por princípios humanitários.

Martins (2004), ao investigar os caminhos do método genealógico na filosofia, elenca Espinosa, Nietzsche e Foucault (nossa referência fundamental) e esclarece que:

\begin{abstract}
A genealogia implica a investigação das causas em um sentido não cartesiano, a saber, sem linearidade, reducionismo ou mecanicismo, como também sem positivismo - características que estão interligadas. A linearidade das causas só é possível se reduzirmos os complexos, vários e variáveis fatores causais a fatores simples, discretos, definíveis, delimitáveis, mecânicos. Assim fazendo, buscamos explicação na positividade de uma análise que, no entanto, para ser possível enrijece fatores que na realidade não são assim tão rígidos (MARTINS, 2004 p.952).
\end{abstract}

Partindo destas considerações, nos vimos diante de uma tarefa complexa e foram necessários o uso de diversas fontes para elaborar uma genealogia abrangente e crítica, congregando uma ampla variedade de discursos, práticas e acontecimentos. Nosso texto foi elaborado com o auxílio de ampla documentação e de uma bibliografia criteriosamente selecionada, com dados e contribuições dos principais periódicos sobre saúde pública brasileiros e também dos sítios eletrônicos de órgãos governamentais oficiais - dentre eles, em especial, o Ministério da Saúde e o Ministério do Meio Ambiente. 
A pesquisa documental, conforme os apontamentos de Sá-Silva et al (2009), consiste em uma técnica exploratória que foi empregada no presente estudo com foco especial em documentos bibliográficos, que favorece a observação da evolução de conceitos e práticas relacionados a um determinado objeto. Cumpre ressaltar que a utilização de uma produção bibliográfica com foco em fontes secundárias não dispensa, de maneira alguma, a compreensão da construção social e histórica dos fatos inerentes a todos os documentos:

\begin{abstract}
A etapa de análise de documento propõe-se a produzir ou reelaborar conhecimentos e criar novas formas de compreender os fenômenos. É condição necessária que os fatos devem ser mencionados, pois constituem os objetos da pesquisa, mas, por si mesmos, não explicam nada. $O$ investigador deve interpretá-los, sintetizar as informações, determinar tendências e na medida do possível fazer a inferência (SÁ-SILVA; ALMEIDA, GUINDANE, 2009 p.10).
\end{abstract}

Estes mesmos autores estabelecem que "a pesquisa documental é um procedimento que se utiliza de métodos e técnicas para a apreensão, compreensão e análise de documentos dos mais variados tipos".

Dessa forma, os documentos foram analisados a partir das categorias biopolítica e governamentalidade com a perspectiva de construir uma genealogia da Vigilância em Saúde Ambiental em território brasileiro. As categorias de análise são discutidas com maior cuidado na abertura da tese.

Ao longo da pesquisa, julgamos pertinente ressaltar, encontramos um vasto tesouro depositado nas plataformas virtuais de pesquisa - onde os periódicos indexados têm significativa relevância na produção de conhecimento em saúde coletiva. Entre elas destacamos:

- A Scielo (Scientific Eletronic Library Online);

- O PUBMED (US National Library of Medicine National Institutes of Health);

- A BVMS (biblioteca Virtual em Saúde).

As palavras chaves utilizadas foram: vigilância ambiental em saúde, vigilância ambiental, vigilância em saúde ambiental, vigilância em saúde, vigilância à saúde, 
vigilância da saúde, meio ambiente e saúde, meio ambiente e saúde pública, história da saúde pública e história ambiental.

Um fato imediatamente se impôs: a produção sobre Vigilância Ambiental no Brasil é recente, com isso, o volume de artigos e textos produzidos é compreensivelmente restrito. Tal contexto nos levou a não determinar um período de tempo específico, deixando em aberto toda a produção que ocorresse na pesquisa. Chegamos, efetivamente a onze documentos, entre artigos, manuais e uma tese, levando em consideração o foco do nosso objeto, ou seja, artigos e textos que tratassem da Vigilância Ambiental/Vigilância em Saúde Ambiental no Brasil. Ademais, da centenas de referências encontradas, menos de uma centena (98) foram efetivamente utilizadas para essa produção por se coadunarem ao contexto e contribuírem para uma interpretação coerente.

Para além destas buscas primárias (ou seja, documentos diretamente ligados ao objeto), que estabeleceram a base de nosso trabalho, pesquisamos profundamente os sites e documentos contidos nos endereços eletrônicos do Ministério da Saúde e do Ministério do Meio Ambiente - em especial no que diz respeito às legislações e documentos técnicos. Tal focalização teve como justificativa critérios importantes em pesquisa documental, em particular: credibilidade, autor, conjuntura do documento e natureza do texto (SÁ-SILVA et al, 2009).

É sobre esse cabedal de informações, legais e históricas, bem como por meio de uma ampla gama de conhecimentos produzidos por estudiosos de relevo em nosso país que buscamos desenvolver nossa tese.

Nosso percurso metodológico percorrerá seis etapas:

1 - Explicitação das chaves foucaultianas escolhidas, a saber: genealogia governamentalidade - biopoder;

2 - Interpretação histórica do surgimento da saúde pública no Brasil, sob os prismas das chaves foucaultianas mencionadas acima; 
3 - Interpretação histórica da emergência e desenvolvimento do capitalismo no Brasil e, sobremodo, de seus impactos ambientais no país;

4 - Partindo dessas interpretações históricas, a formulação em si da genealogia da Vigilância Ambiental, em especial no Brasil;

5 - A elaboração de uma leitura biopolítica da Vigilância Ambiental na atualidade;

6 - Conclusão e avaliação do caminho percorrido.

Buscamos uma síntese genealógica que se faz a partir de acontecimentos que foram se encontrando no tempo e no espaço - histórico e geográfico. Uma síntese possível - não uma síntese imaginada ou ideal. Aqui, interpretar significa avaliar a coerência para a inserção de fatos que não busca uma imagem concebida anteriormente, mas só contempla o objeto ao final - em descoberta.

Cumpre enfatizar a natureza histórica da presente pesquisa. O objeto do nosso estudo, como, aliás, todos, em tese, tem uma historicidade e está ele próprio se movendo na história, ainda em desenvolvimento. Esta compreensão é um dos motivos fundamentais da natureza documental e bibliográfica utilizada em nossa abordagem da metodologia adotada.

\begin{abstract}
A historicidade atravessa todas as formas de pensamento e de ação humanas, e já esta diversidade deixa ver que cada forma possui suas modalidades e suas justificativas próprias, que não somente não se dissolvem neste caráter histórico, mas que tiveram seu nascimento e desenvolveram-se, constituíram-se, segundo este caráter mesmo, que presidiu à ordenação de seus "materiais" (simbólicos e concretos). Foi ao longo deste desenvolvimento que foram criados e ordenados os elementos (conceituais) de inteligibilidade que permitem a assimilação, num dado estágio de conhecimento, e estes próprios elementos informam aqueles do estágio seguinte, tornando-o possível (PATY, 2005 p.376-377).
\end{abstract}

Marques e colaboradores (2018), reforçam bem essa importância no campo da história da saúde: 
O campo de conhecimento da saúde coletiva se apoia nas contribuições teórico metodológicas que compreendem o princípio do processo saúde/doença e a dimensão do acesso aos serviços de saúde como resultados da produção social e histórica de determinada realidade, no caso, a brasileira. O conhecimento histórico no campo da saúde, anteriormente aos anos 1960-1970, pautava-se, como foi dito, em uma compreensão acumulativa, evolutiva e linear, dos processos históricos. Diferentemente disso, os estudos da saúde coletiva buscaram a interpretação dos eventos e fenômenos de saúde articulados a seus contextos, tirando os aspectos hermético e naturalizado que os objetos apresentavam anteriormente. Ou seja, nos estudos precedentes, pensava-se que a ciência poderia ser compreendida como prática laboratorial e de organização de serviços, que as profilaxias dependeriam, por um lado, de uma observação mais aguçada do meio e, por outro, das formas de adoecimento do corpo etc. sem, entretanto, levar em conta aspectos sociais, culturais e políticos, os quais seriam estorvos ao desenvolvimento científico (MARQUES et al, 2018 p.355-356)

Esquecer esse aspecto histórico e complexo seria fugir da proposta genealógica adotada por Foucault.

Aonde chegamos, com o presente trabalho? Trata-se de uma pergunta necessária. Nosso trajeto nos levou a uma interessante genealogia que deu título à tese: da agenda ambiental para a Vigilância Ambiental. Observamos que desde os primórdios da república até o Brasil com tendências políticas neoliberais de nossos dias as intervenções em saúde pública que se conectaram ao meio ambiente foram executadas sobretudo pela força das circunstâncias, pela mais pura e inevitável necessidade. Os trabalhos de Costa (1985) e Hochman (2013) nos levam a essa conclusão logo mais à frente no desenvolvimento.

A concepção clássica de Foucault acerca da biopolítica mostrou-se pertinente se considerarmos que as intervenções que tiveram lugar em território brasileiro, ao longo das décadas, foram organizadas prioritariamente para garantir a sobrevivência da população trabalhadora, responsável por manter em funcionamento a roda da produção de riquezas, e para proteger a saúde das elites - ainda que, em alguns casos apenas idealmente, das próprias classes menos favorecidas. (HOCHMAN, 2013)

Como apresentado com maior propriedade ao longo do texto, buscamos delimitar e estabelecer um conjunto de fases englobando os principais momentos do desenvolvimento da agenda ambiental no Brasil - ao passo que, paralelamente, 
estabelecemos uma leitura crítica de nossa história com toda a força das concepções foucaultianas adotadas.

Encontramos uma Vigilância Ambiental que em sua existência concreta atua com efetividade para questões mais tradicionais - tais como vetores biológicos e padrões básicos de qualidade da água - e de maneira um tanto frágil, correndo o risco de operar como pseudopolítica de proteção, em situações de contaminação do solo, as chamadas áreas contaminadas, se considerarmos apenas o cabedal técnico necessário para identificar diversos contaminantes ambientais e seus riscos ecotoxicológicos.

Pelo exposto logo acima, optamos ainda por uma interpretação biopolítica da genealogia descoberta. Após a leitura, com as lentes foucaultianas, também se fez necessária uma leitura que atualizasse uma interpretação biopolítica da área em análise. 


\subsection{Detalhamento do aporte documental}

Cabe ainda discutir a base documental que fundamenta a pesquisa, para além das referências bibliográficas.

A respeito da produção de Michel Foucault, parece-nos importante destacar que parte de sua obra é oriunda de transcrições de aulas, cursos e palestras por ele ministradas. Para esta pesquisa, utilizamos materiais de sua etapa reflexiva mais tardia, bem afastados do autor que inicialmente produziu a História da Loucura (1961) e mais próximos do escritor da História da Sexualidade (1976-1984).

Além da obra de Michel Foucault, autores que escreveram sobre ele e desenvolveram suas ideias foram importantes para a formulação da perspectiva adotada no presente trabalho, tais como Sandra Caponi (2014), Edgardo Castro (2014), Nikolas Rose (2012, 2013), Mariama Furtado e Ana Szapiro (2012), Grasiele Nespoli (2014), Cláudia Abbê Baêta Neves e Altair Massaro (2009), além de Francisco Ortega (2004). Todos muito contribuíram com suas discussões mais atualizadas sobre a biopolítica em operação, bem como pela crítica a esse modelo. A distância inevitável entre o tempo em que escreveu Foucault e o tempo em que surgiu a Vigilância Ambiental não poderia prescindir dessas contribuições.

Após um mergulho nas principais obras de Michel Foucault, optamos por consultar os clássicos da interpretação histórica e social da saúde em nosso país tarefa que nos levou a autores como Jaime Benchimol (2004), Gilberto Hochman (2004, 2012), Nilson do Rosário Costa (1985), Pedro Jacobi (1989), Caio Prado Júnior (1977), Milton Santos (2013), Nancy Stepan (2004), Raquel Maria Rigotto e Lia Giraldo da Silva Augusto (2007), Ana Maria Azevedo Figueiredo de Souza (2007), Suely Rozenfeld e Edná Alves Costa (2000), Eliseu Alves Waldman (1991) e Jairnilson Silva Paim, Carmem Fontes Teixeira e Ana Luiza Vilasbôas (1998), entre outros pensadores que serão citados ao longo texto. Algumas cartas acerca dos estudos encomendados pelo Rei Dom João VI aos médicos da corte, Manoel Vieira da Silva e Domingos Ribeiro dos Guimarães Peixoto, merecem destaque na documentação 
consultada, em especial quanto ao papel revelador dos primeiros sinais de uma governamentalidade biopolítica em território tupiniquim, no início do século XIX.

A documentação técnica, encontrada com maior facilidade graças à internet, englobou desde o já clássico Dossiê da ABRASCO sobre os agrotóxicos no Brasil, de 2015, até documentos como a Lei 8.080, de 19 de setembro de 1990, o resumo executivo da Conferência Nacional de Saúde Ambiental, de 2009, a Política Nacional de Saúde do Trabalhador e da Trabalhadora, de 2012, os Subsídios para a Construção da Política Nacional de Saúde Ambiental, de 2009, os textos da FUNASA sobre Vigilância Ambiental em Saúde e também os Textos de Epidemiologia para Vigilância Ambiental, de 2002, a Lista Nacional de Agentes Cancerígenos, de 2014, a Portaria 1.378, de 9 de julho de 2013, relativa aos Sistema Nacional de Vigilância em Saúde e de Vigilância Sanitária, o Guia de Vigilância em Saúde do Ministério da Saúde, de 2014, as Análises de Risco Tecnológico e Relações de Áreas Contaminadas da CETESB, Estatísticas Industriais da Confederação Nacional das Indústrias, o documento sobre Segurança Química do Ministério do Meio Ambiente e a mais recente Política Nacional de Vigilância em Saúde de 2018, entre outras legislações que serão mencionadas no corpo do trabalho.

Além desta base teórica, crítica e documental/legal, não seria possível dispensar a leitura de autores, já clássicos na área, que vêm refletindo sobre Vigilância Ambiental, saúde ambiental ou ainda sobre as Vigilâncias em geral, registrando e propriamente concretizando o andar da história destas áreas. Falamos de Lia Giraldo da Silva Augusto (2003), Volney de Magalhães Câmara e Ana Maria Testa Tambellini (1998), Carlos Machado de Freitas (1995), Marcelo Firpo de Souza Porto (1995, 2016), Jorge Mesquita Huet Machado (2011), Helena Ribeiro (2004, 2014), Daniela Buosi Rohlfs (2011), Juliana Wotzasek Rulli Villardi (2015), Christovam Barcellos e Luiz Antônio Dias Quitério (2006), entre outros que serão citados no decorrer do estudo - estudiosos que produziram reflexões determinantes para o pensamento e para a crítica da Vigilância Ambiental entre nós.

Os trabalhos de autores como Henri Acselrad, Cecília Campello do Amaral Mello e Gustavo das Neves Bezerra (2009) sobre Justiça Ambiental; bem como a 
sólida reflexão de Luiz Marques (2016) sobre o capitalismo e sua relação com o colapso ambiental que temos assistido; associados, por fim, à atualização do clássico "Relatório Meadows"1 denominado "The limits to growth" de 1972, pelo próprio coordenador Dennis Meadows (2010) - foram extremamente úteis para a compreensão da situação hodierna. Há ainda a necessidade de destacar a luz lançada pela perspectiva que a epidemiologia crítica de Jaime Breilh (2013) proporcionou à nossa pesquisa.

Foi a partir dessas partes que construímos o cabedal de informações e interpretações que resultaram na genealogia apresentada em nossa tese. Em breve a conceituação de Foucault acerca da genealogia será detalhada, mas julgamos ter evidenciado ao longo dos últimos parágrafos que uma genealogia é produzida necessariamente por múltiplas fontes e perspectivas. Somente tal variedade pode caminhar rumo a ângulos que permitam uma interpretação teórica que se aproxime dos fatos, já que uma área de atuação e conhecimento não surge e se estabelece como ferramenta de política pública sem a influência de diversos movimentos e acontecimentos que a plasmaram.

Desse modo, podemos dizer que as fontes foram operacionalizadas de modo polivalente, ou seja, de artigos foi possível extrair história, de documentos oficiais surgiram definições científicas e em alguns momentos foram as notas de rodapé que iluminaram a busca. Muitas outras fontes foram deixadas de fora, para evitar a repetitividade, e nem todas foram explicitadas nominalmente em nosso breve percurso até aqui, mas serão devidamente creditadas ao longo do texto.

Salvo nos documentos oficiais, a pesquisa dos primórdios do que veio a se tornar a Vigilância Ambiental foi traçada a partir de muitas leituras de fontes documentais múltiplas - com foco em situações que evidenciassem o andamento de uma governamentalidade biopolítica. Para compreender melhor tais conceitos, nos

\footnotetext{
${ }^{1}$ O Relatório Meadows foi produzido em 1972, sob o título "The limits to growth". Foi um impactante estudo realizado pelo Clube de Roma, um grupo de pesquisadores distribuídos pelo mundo e liderados por Dennis Meadows, a pesquisa examinou a conjugação de cinco fatores básicos quanto ao crescimento: população, produção agrícola, recursos naturais, produção industrial e poluição.
} 
dedicaremos agora a discutir as chaves foucaultianas que adotamos para iniciar o percurso. 


\title{
Capítulo 2 \\ Chaves Foucaultianas e a centralidade do risco
}

\author{
Genealogia não é gênese
}

Na obra organizada por Roberto Machado, intitulada "Microfísica do Poder", mais especificamente no texto em que Michel Foucault trabalha a ideia de genealogia e poder, podemos encontrar a seguinte colocação:

\begin{abstract}
Chamemos provisoriamente genealogia o acoplamento do conhecimento com as memórias locais, que permite a constituição de um saber histórico de lutas e a utilização desse saber nas táticas atuais. Nessa atividade, que se pode chamar genealógica, não se trata, de modo algum, de opor a unidade abstrata da teoria à multiplicidade concreta dos fatos e de desclassificar o especulativo para Ihe opor, em forma de cientificismo, o rigor de um conhecimento sistemático. Não é um empirismo nem um positivismo, no sentido habitual do termo, que permeiam o projeto genealógico. Trata-se de ativar saberes locais, descontínuos, desqualificados, não legitimados, contra a instância teórica unitária que pretenderia depurá-los, hierarquizá-los, ordená-los em nome de um conhecimento verdadeiro, em nome dos direitos de uma ciência detida por alguns. As genealogias não são, portanto, retornos positivistas a uma forma de ciência mais atenta ou mais exata, mas anticiências. Não que reivindiquem o direito lírico à ignorância ou ao não saber; não que se trate da recusa de saber ou de ativar ou ressaltar os prestígios de uma experiência imediata não ainda captada pelo saber. Tratase da insurreição dos saberes não tanto contra os conteúdos, os métodos e os conceitos de uma ciência, mas de uma insurreição dos saberes antes de tudo contra os efeitos de poder centralizadores que estão ligados à instituição e ao funcionamento de um discurso científico organizado no interior de uma sociedade como a nossa. Pouco importa que a institucionalização do discurso científico se realize em uma universidade ou, de modo mais geral, em um aparelho político com todas as suas aferências, como no caso do marxismo; são os efeitos de poder próprios ao discurso considerado como científico que a genealogia deve combater (FOUCAULT, 2015a p.267-268).
\end{abstract}

Tomemos ainda alguns dos cursos biopolíticos, "Em Defesa da Sociedade", "Segurança, Território e População" e o "Nascimento da Biopolítica" - essa classificação para os cursos foi elaborada por Edgardo Castro (CASTRO, 2014).

Logo na primeira aula de "Em Defesa da Sociedade", em 07 de janeiro de 1976 no Collège de France, o tema da genealogia foi abordado. "É exatamente contra os efeitos de poder próprios de um discurso considerado científico que a genealogia deve travar o combate" (FOUCAULT, 2008b). Que dizer disso? Pretende-se olhar muito mais os modos como as relações de poder se manifestam no tecido social do que olhar para o discurso formal estabelecido. Quando pontuamos há pouco que 
"genealogia não é gênese", entendemos que o termo gênese pressuporia uma origem única ou no máximo dupla, quando na verdade o saber e o poder se constroem em várias instâncias e discursos diferentes - nos dizeres de Foucault: o poder circula, transita entre os indivíduos, não se aplica sobre ele, mas o constrói. Especificamente neste curso Foucault vai analisar o modo como os detentores do poder contam a história para legitimar esse poder. Todo saber traria uma ambição de poder intrínseca, de modo que os outros saberes deveriam ser sujeitados ao científico - e isso seria fabricado no discurso jurídico, ao normatizar e legalizar determinado discurso científico. Para entender como o poder circula na sociedade ele analisará o discurso do soberano, das classes e das raças para assim construir uma análise genealógica dos mecanismos institucionais de poder de seus dias - culminando no que ele chamou de biopoder e biopolítica.

Não temos dúvidas quanto ao fato de que as "Vigilâncias" não emergiram de uma reflexão a priori, mas de necessidades sociais graves e concretas; ao longo do tempo elas foram se desenvolvendo, se institucionalizando e operando em razão de um projeto político maior - e em alguma medida como resultado do conflito de projetos políticos em disputa. Por isso, tomamos a genealogia foucaultiana como orientação metodológica.

Ao estudar a história do Brasil com vistas a construir nossa genealogia elegemos três eixos essenciais: a construção da saúde pública no Brasil, o desenvolvimento industrial e seus impactos sobre o meio ambiente e a população. $O$ desenvolvimento histórico desses elementos conflui para a formação da Vigilância em Saúde Ambiental. 


\section{1 - Governamentalidade}

Ao buscar construir o conceito de governamentalidade, Foucault inicia suas reflexões negando uma origem greco-romana e encontrando no Oriente pré-cristão (egípcios, babilônios e hebreus) a ideia de um governo pastoral, que mais tarde se apresentará como governo de almas no cristianismo. Com isso o autor busca articular à ideia de governamentalidade qualidades como proteção, bem e salvação - em suma um poder de cuidado.

Mas cuidado com o quê? Com a população. E em que contexto? Num campo relacional de forças competitivas em pleno desenvolvimento dos Estados nacionais na Europa. Dentre os mecanismos estratégicos para a execução da tarefa está o surgimento da polícia, esta entendida inicialmente como um conjunto, uma associação regida por uma autoridade pública: regimento-polícia. Mais tarde a polícia se desenvolverá como o cálculo - palavra muito utilizada por Foucault - entre a ordem interna do Estado e o seu crescimento, o "esplendor" e o bom uso das forças disponíveis. E qual é o instrumento comum que as polícias dos Estados vão desenvolver? A estatística: a ciência do Estado. Nosso autor reforça que a estatística nasce por causa da polícia.

Importante ressaltar que a polícia não aparece de modo uniforme nos Estados nascentes. Na Itália a prioridade foi diplomática - e na Alemanha a polícia foi fundamental, vindo a se difundir para toda a Europa.

Foucault arremata:

Concretamente, a polícia deverá ser o quê? Pois bem, ela deverá anotar como instrumento tudo o que for necessário e suficiente para que essa atividade do homem se integre efetivamente ao Estado, às suas forças, ao desenvolvimento das forças do Estado, e deverá fazer de maneira que o Estado possa, por sua vez, estimular, determinar e orientar essa atividade de uma maneira que seja efetivamente útil ao Estado. Numa palavra, trata-se da criação da utilidade estatal, a partir de e através da atividade dos homens (FOUCAULT, 2008c p.433).

Essa polícia atuará cuidando da quantidade de homens e da sua conexão com o território, das necessidades gerais de vida tal como a segurança e qualidade dos alimentos, da saúde do coletivo, vigiando e controlando tudo que possa causar 
doenças visando salvaguardar justamente a possibilidade do trabalho e da ocupação, da produtividade; cuidará ainda da atividade, da garantia de trabalho, inclusive aos pobres úteis, e até mesmo da regulamentação de ofícios. Finalmente, a polícia viabilizará a circulação das mercadorias além de produzir regras para que a circulação em geral se efetue.

Nas palavras de Foucault, "a polícia é o conjunto das intervenções e dos meios que garantem que viver, melhor que viver, coexistir, será efetivamente útil à constituição, ao aumento das forças do Estado" (FOUCAULT, 2008c).

Agora, a vida de cada indivíduo interessa ao Estado. Foucault acrescenta: fazer da felicidade dos homens a força do Estado. E mais, tudo isso passa a operar e ter importância na cidade e por causa da cidade; é a coexistência que demanda a polícia, ou ainda a circulação de homens e mercadorias. O autor destaca que essa dinâmica assume tais contornos em virtude dos movimentos mais amplos do desenvolvimento comercial Europeu, sob o mercantilismo.

Onde essa discussão desemboca? Com Foucault:

\begin{abstract}
Se a governamentalidade do Estado se interessa, e pela primeira vez, pela materialidade fina da existência e da coexistência humana, pela materialidade fina da troca e da circulação, se esse ser e esse melhor-estar é levado em conta pela primeira vez pela governamentalidade do Estado, e isso através da cidade e através de problemas como o da saúde, das ruas, dos mercados, dos cereais, das estradas, é porque o comércio é pensado nesse momento como o instrumento principal da força desse Estado e, portanto, como o objetivo privilegiado de uma polícia que tem por objetivo o crescimento das forças do Estado (FOUCAULT, 2008c p.456).
\end{abstract}

Com isso se instaura o período do regulamento, da disciplina, das normas, "o mundo da disciplina", tendo a polícia como o "Golpe de Estado permanente".

Apesar de estarmos falando da Europa dos séculos XVII e XVIII, em especial da França e da Alemanha, a semelhança das funções da polícia com a atual definição de Vigilância Sanitária no Brasil é impressionante.

Nos termos da Lei 8.080, de 19 de setembro de 1990: 
Entende-se por vigilância sanitária um conjunto de ações capaz de eliminar, diminuir ou prevenir riscos à saúde e de intervir nos problemas sanitários decorrentes do meio ambiente, da produção e circulação de bens e da prestação de serviços de interesse da saúde (BRASIL, 1990).

Continuamos falando de convivência, coexistência e fortalecimento do Estado. Vamos retomar a exposição de onde paramos, reforçando que voltaremos à Europa do passado.

De acordo com Foucault, no andar do século XVIII a governamentalidade policial vai entrando em crise, aos poucos a regulamentação disciplinar deixa de ser interessante e as relações e normas passam a vigorar em torno da economia - que demandará cada vez menor controle e mais liberdade para que os interesses individuais venham a definir, conforme suas leis "naturais", as condições de vida e prosperidade viáveis. O Estado policial entra em crise e passa a ser um empecilho para a economia política em nascimento. Obviamente isso se dá concomitantemente, sem rupturas absolutas. O Estado passará a ser demandado para a gestão da sociedade civil sob o bastão do saber científico, que via economia imperará. Nesse período a população surgirá como ponto importante a ser compreendido cientificamente - tal qual o mercado, ela deverá ser governada não indivíduo a indivíduo, mas como um todo: nascerá a medicina social no século XVIII. As regulações devem ser tais que atuem em conformidade com as leis naturais da população e do mercado, numa palavra "gerir" através de mecanismos de segurança esses fenômenos "naturais".

\footnotetext{
Em primeiro lugar, a população - a perspectiva da população, a realidade dos fenômenos próprios à população - permitirá eliminar definitivamente o modelo da família e centralizar a noção de economia em outra coisa. De fato, se a estatística tinha até então funcionado no interior do quadro administrativo da soberania, ela vai revelar pouco a pouco que a população tem uma regularidade própria: número de mortos, de doentes, regularidade de acidentes, etc.; a estatística revela também que a população tem características próprias e que seus fenômenos são irredutíveis aos da família: as grandes epidemias, a mortalidade endêmica, a espiral do trabalho e da riqueza, etc.; revela finalmente que através de seus deslocamentos, de sua atividade, a população produz efeitos econômicos específicos (FOUCAULT, 2008c p.138).
} 
É na população que se aplica o que Foucault chama de governamentalidade, entendendo por este conceito o conjunto de instituições, procedimentos, análises, cálculos e táticas que permitem exercer o poder sobre a população - é uma tendência de desenvolvimento do governo, um processo (FOUCAULT, 2015a).

Na conferência denominada "Nascimento da Medicina Social", realizada no Brasil em 1974, Foucault explicita esse processo que tanto nos interessa. Ele reputa o nascimento da medicina social ao surgimento do capitalismo em fins do século XVIII e início do XIX, com a socialização do corpo como força de produção. Ao contrário do que se poderia supor, é uma medicina com forte ênfase no social e não no individual aquela que aparece aqui. Ela deteve aspectos individuais muito mais intensos em fases anteriores ao capitalismo. A medicina social é elaborada em três momentos de acordo com Foucault: medicina de Estado, urbana e medicina da força de trabalho.

Cada etapa pode ser remetida a um país, porém sem grandes demarcações. A Alemanha, por exemplo, inicia a programação da polícia médica, noção criada nesse país em 1764, e com isso passa a exercer controle sobre a população através do registro de eventos epidêmicos e endêmicos, normalização do ensino médico, controle administrativo da atividade médica e criação de um corpo médico de funcionários estatais. Na Alemanha, para Foucault, a meta da medicina era fortalecer e desenvolver o Estado através de suas práticas.

Posteriormente o autor se reporta à França, com a urbanização sendo o foco de socialização da medicina. O desenvolvimento industrial, os pobres do campo, as revoltas de subsistência traziam à cidade um ambiente de "pequenos pânicos" relativos aos cemitérios, esgotos, construções, "vagabundagem", etc. - situações que traziam à tona a questão dos problemas sanitários dos tecidos urbanos. Criou-se um sistema de "vigilância generalizada que dividia, esquadrinhava o espaço urbano" pelo medo de epidemias, em especial da lepra e da peste.

Em essência, a medicina urbana francesa buscava analisar e organizar espaços de acúmulo e perigo como cemitérios e matadouros, cuidar e controlar da questão da boa circulação do ar e das águas, estabelecer algo próximo do conceito 
atual de um planejamento urbano relativo à moradias, fontes de água e esgoto, distribuídos adequadamente para que um não contamine o outro. A medicina urbana francesa produz a noção de salubridade e era mais conectada às coisas do que às pessoas.

E na Inglaterra termina o processo de nascimento da medicina social proposto por Foucault - através da medicina dos pobres, da força de trabalho. Somente no final do século XIX o pobre aparece como um perigo, entre as razões estão o fato do contingente populacional anterior não ser tão grande e a funcionalidade do pobre na dinâmica da cidade ser, naquele momento, importante. Eles levavam cartas, distribuíam água, retiravam dejetos, entre outras tarefas menores. Porém, com o desenvolvimento industrial e comercial o pobre "sobrou" na cidade e passou a ser um problema. Eles se revoltavam, não trabalhavam, pouco possuíam e eram doentes. Eles precisavam ser controlados e cuidados, para benefício da elite burguesa que os temia. Desse momento são "A lei dos pobres" e os health services, formas estratégicas de gerir a camada mais pobre da população através de vacinação, registro de estatísticas e destruição de focos insalubres, por exemplo.

A medicina social inglesa foi a que vingou e evoluiu para a concomitância de três coisas: assistência ao pobre, uma medicina administrativa (tipo a medicina urbana francesa) e uma medicina privada para os que tinham meios de pagar (FOUCAULT, 2015a).

Foi também no Brasil, na Universidade Estadual do Rio de Janeiro em 1974, que Foucault trabalhou a ideia do "Nascimento do Hospital" - e isso se deu paralelamente ao nascimento da medicina social abordado há pouco. É do final do século XVIII a preocupação com os hospitais enquanto locais passíveis de curar antes disso o hospital era um lugar de assistência aos pobres, loucos e prostitutas, um lugar de separação e exclusão. Um lugar de morrer, e não de curar. E mais: era um lugar excluído da formação médica, algo impensável na atualidade.

Para o hospital ser pensado como um lugar de cura foi necessário primeiramente agir sobre os males que ele mesmo trazia aos internos e aos seus 
arredores. O primeiro tipo de hospital a ser "medicalizado" foi o hospital marítimo e o hospital militar, tendo a quarentena como tecnologia de intervenção de maior destaque.

Para toda essa análise de "nascimentos" da medicina social e do hospital, destacamos uma colocação que consta em O Nascimento do Hospital: "é nessa época que a formação do indivíduo, sua capacidade, suas aptidões passam a ter um preço para a sociedade" (FOUCAULT, 2015a).

E o destaque acima explica uma razão essencial para a importância do hospital como instância disciplinar de controle, sobrevida e valorização econômica do investimento feito pela sociedade em indivíduos cada vez mais custosos para formar, em especial os soldados.

É esse o período chamado de sociedade disciplinar. Com a individualização do espaço, classificando, distribuindo, normalizando e vigiando através de hierarquias, garantindo o exercício do poder do Estado em cada pessoa. Com a disciplinarização do espaço hospitalar e a compreensão da doença como um fenômeno da natureza, o hospital passa aos poucos a se tornar um espaço médico.

Com isso, questões como onde localizar o hospital, como distribuir os doentes em seu interior, como deve ser o seu interior para o bem dos doentes, quem deve ser o responsável pela organização e disciplinarização hospitalar para que este passe a ser um lugar de cura, um lugar que promova saúde, são recorrentes. É o médico que passa a responder por isso, invertendo seu papel com o pessoal religioso. Passa também a registrar e estudar, compartilhando com outros tratamentos e curas. Com isso transforma-se em lugar de formação obrigatório e produção de saber médico.

O indivíduo e a população são dados simultaneamente como objetos de saber e alvos de intervenção da medicina, graças à tecnologia hospitalar. A redistribuição dessas duas medicinas será um fenômeno próprio do século XIX. A medicina que se forma no século XVIII é tanto uma medicina do indivíduo como da população (FOUCAULT, 2015a p. 189). 
O exposto acima se refere ao fim do século XIX e início do século $X X$, tanto na Europa quanto no Brasil - mas na contemporaneidade a ideia de pastorado deve ser contextualizada.

\begin{abstract}
Esse poder pastoral contemporâneo não está organizado e administrado pelo "Estado", ainda que usemos esse termo para abranger todo o complexo de provisão legislativa, organizações de pesquisa financiadas pelo Estado e comitês nacionais de investimento de aspectos médicos e éticos da nova biomedicina. Ele acontece em um campo plural e controverso, pervagado pelos códigos proferidos por comitês éticos e por associações profissionais, pelas descobertas empíricas geradas pelos pesquisadores, pelas atitudes e pelos critérios usados pelos empregadores e asseguradores, pelos testes desenvolvidos e promovidos por psicólogos e companhias biotécnicas, pelo aconselhamento oferecido pelas organizações de autoajuda e até mesmo, poder-se-ia acrescentar, pelas perspectivas críticas oferecidas por organizações religiosas e por críticos sociológicos (ROSE, 2013 p.111).
\end{abstract}

Agora, o pastoral está fortemente vinculado à noção de subjetividade e escolha, ainda que capturadas pelo aparato médico ideológico do capital (ROSE, 2013).

Quando Foucault se dedica a compreender o modo de atuação da biopolítica contemporânea, ele se demora muito na análise da economia política moderna e sua forma de operar, sua racionalidade e, como já vimos, sua governamentalidade. A mudança no cenário atual é muito interessante, pois implica em governar e controlar sob a égide do mercado.

Toda a questão da razão governamental crítica vai girar em como não governar demais. Não é ao abuso da soberania que se vai objetar, é ao excesso de governo. E é comparativamente ao excesso de governo, ou em todo caso a delimitação do que seria excessivo para um governo, que se vai medir a racionalidade da prática governamental (FOUCAULT, 2008a p.18).

Afinal:

A partir da nova razão governamental - e esse é o ponto de descolamento entre a antiga e a nova, entre a razão de Estado e a razão de Estado mínimo -, a partir de então o governo já não precisa intervir, já não age diretamente sobre as coisas e sobre as pessoas, só pode agir, só está legitimado, fundado em direito e em razão para intervir na medida em que o interesse, os interesses, os jogos de interesse tornam determinado indivíduo ou determinada coisa, determinado bem ou determinada riqueza, ou determinado processo, de certo interesse para os indivíduos, ou para o conjunto dos indivíduos, ou para os interesses de determinado indivíduo confrontados ao interesse de todos, etc. $O$ governo só se interessa pelos interesses (FOUCAULT, 2008a p.62). 
Do período do nascimento da medicina social para o presente ocorre uma inversão: o Estado menos controlador passa a agenciar, mas não a controlar intervenções e tecnologias médicas. Tal inversão de papel é fundamental para observarmos como a questão ambiental conectada a fatores não biológicos, mais precisamente, não se torna de imediato objeto da saúde pública.

Nespoli (2014) esclarece:

Na sociedade moderna, o que generaliza o poder não é a consciência universal da lei, mas a trama dos mecanismos de governo da vida. Nesse sentido, o Estado se organiza e funciona por uma combinação de técnicas de individuação e de procedimentos de totalização relacionados com a incorporação de diferentes tecnologias que ele significa nas noções de disciplina, técnicas de si, biopolítica, poder pastoral e 'governamentalidade', que formam, acima de tudo, modalidades de captura e submissão do corpo às forças produtivas (NESPOLI, 2014 p.62).

Com isso, podemos agora nos aproximar da nossa última chave de análise: o que Foucault chamará de biopolítica. 


\title{
2.2 - Biopolítica/biopoder
}

Já em o Nascimento da Medicina Social Foucault explicita: "o corpo é uma realidade biopolítica. A medicina é uma estratégia biopolítica" (FOUCAULT, 2015a). Ao falar de poder ele busca ir além das grandes estruturas e se preocupa com os mecanismos e relações que operam como estratégias de manutenção do status quo em plena dinâmica e transformação.

\begin{abstract}
A biopolítica é uma inversão da lógica de poder do soberano:
E eu creio que, justamente, uma das mais maciças transformações do direito político do século XIX consistiu, não digo exatamente em substituir, mas em completar esse velho direito de soberania - fazer morrer e deixar viver - com outro novo direito, que não vai apagar o primeiro, mas vai penetrá-lo, perpassá-lo, modificá-lo, e que vai ser um direito, ou melhor um poder exatamente inverso: poder de "fazer" viver e de "deixar" morrer. O direito de soberania é, portanto, o de fazer morrer e deixar viver. E depois, este novo direito é que se instala: o direito de fazer viver e deixar morrer (FOUCAULT, 2016 p.202).
\end{abstract}

Mais incisivamente, o filósofo arremata que:

A preocupação com as relações entre a espécie humana, os seres humanos enquanto espécie, enquanto seres vivos e seu meio, seu meio de existência - sejam os efeitos brutos do meio geográfico, climático, hidrográfico: os problemas, por exemplo dos pântanos, as epidemias ligadas à existência dos pântanos durante toda a primeira metade do século XIX. E, igualmente, o problema desse meio, na medida em que não é um meio natural e em que repercute a população; um meio que foi criado por ela. Será, essencialmente, o problema da cidade. Eu lhes assinalo aqui, simplesmente, alguns dos pontos a partir dos quais se constituiu essa biopolítica, algumas de suas práticas e as primeiras de suas áreas de intervenção, de saber e de poder ao mesmo tempo: é da natalidade, da morbidade, das incapacidades biológicas diversas, dos efeitos do meio, é disso tudo que a biopolítica vai extrair seu saber e definir o campo de intervenção do seu poder (FOUCAULT, 2016 p.206).

É nessa perspectiva - que permanece ainda exata - que visualizamos a Vigilância em Saúde como campo de ação biopolítico claro, com métodos e princípios que se ocupam exatamente do ângulo citado acima. Em especial na área ambiental, observaremos mais à frente uma nova inversão.

Na lógica do liberalismo, a biopolítica se inscreve no jogo liberdade e segurança que a nova arte de governar impõe: buscando equilibrar o individual e o coletivo, tendo a segurança e o risco como dispositivos (FOUCAULT, 2008a). 
Caponi (2014) elucida ainda mais a colocação acima:

Nas sociedades liberais os Estados se vinculam com a população pela mediação de um "pacto de segurança". Isto supõe que, por um lado surge o compromisso de intervir na antecipação de tudo aquilo que possa representar acidente, dano ou risco, e que por outro lado esse compromisso os autoriza a realizar intervenções extralegais no momento em que se considere necessário. Desse modo, intervenções que vão desde a simples proibição de fumar até os grampos nos celulares, passando pela detecção de patologias mentais na infância, já não serão vistas como excesso de poder, mas sim como excesso de preocupação e proteção dos Estados (CAPONI, 2014 p.35).

Um autor contemporâneo importante nesta área é Nikolas Rose. Ele atualiza o debate foucaultiano para uma realidade onde as implicações biopolíticas são ainda maiores - a biopolítica de hoje é molecular:

A política de vida do nossa século parece bem diferente. Não está delimitada
nem pelos polos de doença e saúde, nem focalizada em eliminar patologias
para proteger o destino da nação. Ao contrário, está preocupada com nossas
crescentes capacidades de controlar, administrar, projetar, remodelar e
modular as próprias capacidades vitais dos seres humanos enquanto
criaturas viventes. É, como procuro demonstrar, uma política "da vida em si
mesma" (ROSE, 2013 p.16).

Mercadização, autonomização e responsabilização fazem parte das estratégias de saúde de hoje. Mais ainda:

\begin{abstract}
Atualmente, no nível molecular é que a vida humana é compreendida, no nível molecular é que seus processos podem ser anatomizados, e no nível molecular é que a vida agora pode ser manipulada. Nesse nível, parece, nada existe de místico ou de incompreensível acerca de nossa vitalidade quaisquer coisas e todas as coisas parecem, em princípio, ser inteligíveis e, consequentemente, abertas a intervenções calculadas a serviço de nossos desejos acerca do tipo de pessoas que nós mesmos e nossos filhos queremos ser (ROSE, 2013 p.17).
\end{abstract}

Determinantes sociais e ambientais passam a ser medicalizados e mercadizados, ou seja, tornam-se um valor para acionistas. E a forma de controle e indução é muita mais poderosa do que o poder disciplinar de polícia, são as redes sociais, o marketing, aliado à necessidade de administração do desempenho social, do estresse, entre outras construções (ROSE, 2013). Enfim, a possibilidade de administrar, com o poder médico, um 'si-mesmo' neuroquímico (ROSE, 2013), por exemplo, e tudo isso apesar de todas as questões ambientais e sociais que abordaremos à frente. 
A molecularização da política vital pode, de alguma forma, fazer supor que todos somos, em algum aspecto, sintomática ou assintomaticamente, doentes. "Quase toda a capacidade do corpo e da alma - força, persistência, atenção, inteligência e a própria duração da vida - parece potencialmente aberta ao melhoramento mediante intervenção tecnológica" (ROSE, 2013). Todos temos um 'biovalor' a ser explorado.

Para além de tudo que observamos acerca da governamentalidade, a medicina é importante para a arte de governar os outros e a si mesmo. O novo pastor é o médico, o psicólogo, o farmacêutico, o educador físico e outros profissionais da expertise somática. "A biologia já não é destino" (ROSE, 2013).

Lidamos com um paradoxo cada vez mais agudo: controlar, monitorar, vigiar e proteger garantindo a liberdade econômica, e em nome dessa liberdade econômica, considerando a capacidade que o mercado tem de promover uma espécie de gerenciamento da vida e da morte. Até que ponto se protege tendo a economia e os interesses de mercado como balizadores macro políticos? Fazendo viver e deixando morrer? Em breve retomaremos esse debate. 


\section{3 - A centralidade do Risco}

Ao estudar a produção acadêmica brasileira sobre saúde coletiva, observamos o risco como uma categoria polissêmica e sob forte influência cultural. Ao redor de nossa construção teórica o risco tudo permeia, como discutido há pouco.

Segundo Czeresnia (2013), o conceito de risco epidemiológico emerge no contexto do estudo das doenças transmissíveis:

...pois a identificação de microrganismos não foi suficiente para explicar totalmente as causas da sua ocorrência. Por exemplo, nem todos os indivíduos que entram em contato com os microrganismos adoecem; os que adoecem não apresentam a mesma gravidade. Essa constatação estimulou a utilização da estatística para buscar avaliar a probabilidade da interferência de outros fatores, além do chamado agente etiológico, no processo (CZERESNIA, 2013 p.77).

Tratando do risco epidemiológico, Luiz \& Cohn (2006) destacam três tipos de abordagens na literatura. A primeira, o risco individual, que trata do cálculo do risco individual a partir de estudos epidemiológicos e estatísticos vitais. A segunda, estratégias de risco, que visam maximizar a eficiência de alocação de recursos públicos em populações vulneráveis. A terceira, análise de risco, que trabalha com a avaliação de tecnologias e produtos. Elas definem risco epidemiológico como "a probabilidade de ocorrência de um determinado evento relacionado à saúde, estimado a partir do que ocorreu no passado recente" (LUIZ; COHN, 2006).

Ao longo da abordagem de nosso objeto de estudo, podemos dizer que as três abordagens se conjugam e interagem, compondo um discurso normativo abrangente.

Em essência, o risco tem um caráter importante: ele substitui atualmente a noção de fortuna. O conceito de risco tem um poder de previsão que, quando cientificamente amparado, pode substituir um evento negativo por outro positivo, ou pela normalidade esperada. Nós confiamos no risco. Ao antecipar uma ocorrência 
provável, ele simboliza um dano evitado, ou ainda a opção de assunção de um risco calculado (GUIDDENS, 1991).

E o que se busca com o conhecimento do risco? A segurança! "Pode-se definir 'segurança' como uma situação na qual um conjunto específico de perigos está neutralizado ou minimizado", já que "o conhecimento sobre a vida social transcende as intenções daqueles que o aplicam para fins transformativos" (GUIDDENS, 1991).

É também através da noção de risco que o Estado exerce o seu poder de controle, monitoramento e adequação ao padrão estabelecido e legalizado. A percepção do risco, pelo agente sanitário por exemplo, é o modo como se exerce o poder diante do regulado - a confissão deste, que deve se dar mediante a defesa e a adequação, conformando-se e se sujeitando à cientificidade do mecanismo adotado pelo Estado. O risco é latente, jaz escondido nas ações e ambientes da sociedade e deve ser revelado e suprimido. Tal é o espírito, já que ao normatizar o risco o agente do Estado tem o poder de proteger e, com isso, culpar - ocultando o paradoxo que Ihe é implícito no campo da saúde: proteger/controlar/vigiar a vida e garantir a reprodução da ordem hegemônica que Breilh (2013) chamou de economia da morte.

\begin{abstract}
A utilização do perfil do risco para delimitar fundos de risco tem uma história muito longa, remontando aos próprios inícios da indústria de seguros. O perfil de risco, mais do que agir "atuariamente" ou asseguradamente na população de modo geral, usa o conhecimento probabilístico e epidemiológico para identificar fatores associados com riscos mais elevados de determinadas formas de saúde precária, problemas de reprodução ou outras formas de patologia e, em seguida, destinar as pessoas aos fundos de risco usando um algoritmo composto por esses fatores. No campo da saúde, à medida que o delineamento de risco se desenvolveu a partir de meados do século $X X$, perfis de risco, escalas e índices eram usados para identificar aqueles que se enquadravam nos grupos com um risco significativamente maior do que a média, a fim de intervir preventivamente neles (ROSE, 2013 p.109).
\end{abstract}

O risco é o principal dispositivo do campo da saúde para aplicação da sua lógica de poder - sua biopolítica. Ele denuncia uma espécie de perigo, de cunho social ou não, a colonizar o nosso futuro. Parece-nos interessante perguntar: o risco, ao induzir ações de controle e monitoramento, não pode produzir, com seus próprios atos, iatrogenias que de outra forma não ocorreriam? 
Seja como for, o risco é o dispositivo atual das ações biopolíticas que são informadas pelas Vigilâncias. O risco é a base da regulação. Em qualquer ação de vigilância a pergunta é sempre necessária: qual o risco? Qual a probabilidade? Qual a possibilidade? Podemos através dos dispositivos que dispomos atuar na perspectiva da proteção? Devemos buscar outros dispositivos? Lembremos com Ana Maria Figueiredo (2007), refletindo sobre a Vigilância Sanitária, que "a natureza da ação de controle do risco sanitário acarreta a necessidade de fundamentação calcada, além da percepção individual, no reconhecimento social e no conhecimento jurídico". A mesma autora pontua que, a depender da abrangência do conceito de risco adotado, os modos de intervenção necessariamente irão apresentar diferentes características (SOUZA, 2007).

É fato que não somos capazes de prever todas as probabilidades e possibilidades, existem sempre elementos que escapam diante de uma realidade tão complexa, tão rizomática. Somos surpreendidos por emergências inesperadas em todos os campos e, nesse momento, o risco nunca percebido surge com toda a sua obviedade. $\mathrm{Na}$ área ambiental observaremos que nem toda surpresa deveria ser "desconhecida".

Nikolas Rose aponta que por mais de 150 anos a avaliação e o gerenciamento do risco têm sido fundamentais para a biopolítica. Desde Edwin Chadwick e Willian Farr, na Inglaterra, foi pela avaliação de risco (ainda que não assim denominada) que as políticas de saúde foram se desenvolvendo na Europa e no Brasil (ROSE, 2013), como veremos na sequência.

No entanto, o poder de previsão - probabilística, lembremos sempre - em tempos de biomedicina molecular é extremamente mais potente e a possibilidade de cálculos de risco serem tomados em perspectiva determinista pelo mercado é um viés importante.

É aqui que a crítica epidemiológica - ou a epidemiologia crítica - de Jaime Breilh deve aparecer mais uma vez. O olhar para os 'fatores de risco' reduz, esvazia uma leitura que considera toda a práxis envolvida. Tomemos, especificamente, um 
exemplo do campo ambiental, a 'exposição' de trabalhadores que utilizam agrotóxicos. Trata-se de uma probabilidade o seu adoecimento, sua intoxicação? É dado a ele escolher quanto a isso? Ele não depende de toda essa estrutura para atender suas necessidades? Aqui, podemos falar em 'imposição' e não exposição, e de intoxicação contínua e concreta, mais propriamente do que de 'risco'. Ultrapassamos a possibilidade e adentramos uma cadeia de fenômenos que 'impõem' as condições de trabalho e meio ambiente.

\begin{abstract}
A distinção entre essas formas de 'ex'posição, ou melhor, entre as formas de exposição ocasional e crônica e a 'im'posição (ou exposição permanente e intrínseca), é importante porque permite separar os processos contingentes e tem um grau de probabilidade dos processos que são inerentes aos modos de vida e atuam de forma invariável, e que, por conseguinte, têm zero grau de liberdade. Estes últimos, para serem modificados - ou melhor, eliminados - como determinantes epidemiológicos, requerem uma transformação do modo de vida, porque os ajustes ou reformas superficiais não põem fim a seu impacto (BREILH, 2013 p.207).
\end{abstract}

O risco não deve mascarar um fato. O movimento denominado Justiça Ambiental, que destacaremos mais à frente, busca demonstrar, somando muito à crítica de Breilh e ao nosso tema, que de modo algum a poluição ambiental é de fato universal. Se, de qualquer modo, ela atinge a todos, a distribuição não é igual e incide muito especialmente sobre as camadas mais pobres e desprotegidas da população. Não se tratam de noções generalizantes como "humanidade" ou "sociedade", entre outras, mas de parcelas da população que sofrem efeitos em proporções bem maiores.

AUGUSTO (2003) nos fornece mais um destaque importante sobre a ideia de risco. Trata-se da diferenciação entre causa e contexto. Se a causa é o que produz um acontecimento, o contexto opera com a noção dos componentes indispensáveis que circundam a causa e sem os quais o evento indesejado não ocorreria. Em termos de risco ambiental, tal visão é fundamental e protetora contra perspectivas monocausais.

$\mathrm{Na}$ atual Vigilância em saúde e por isso também na Vigilância Ambiental, tudo é construído em torno da ideia de risco. Trata-se de um operador básico para movimentar a engrenagem de ações de saúde que determinado risco pode demandar. 


\title{
Capítulo 3
}

\section{Controlar para progredir: estratégias biopolíticas no Brasil}

Um dos mais interessantes registros que encontramos na história da saúde pública brasileira data de 1808, em um texto chamado "Reflexões Sobre Alguns dos Meios Propostos Por Mais Conducentes para Melhorar o Clima da Cidade do Rio de Janeiro" - de Manoel Vieira da Silva. Vieira da Silva era um médico da corte de Dom João VI e elaborou o referido trabalho a pedido do Rei. No texto, observamos curiosos trechos cujas reflexões estavam alinhadas com a perspectiva da teoria miasmática e da medicina das cidades - as teorias em voga então na Europa. No espírito do texto, fica nítida a necessidade de tornar mais saudável um território ainda cheio de ameaças à saúde e, assim, favorecer o comércio e o subsequente acúmulo de riquezas.

Os paralelos com o que Foucault descreveu em O Nascimento da Medicina Social são notáveis. O texto de Vieira da Silva começa exatamente assim:

\begin{abstract}
A causa da saúde pública em todos os tempos tem merecido as primeiras atenções dos grandes legisladores; quando o número de indivíduos sociais tem diminuído, impossibilita-se a execução da lei, muda o seu objeto e, em consequência, a sua natureza, que deve ser relativa ao estado da população; e se o descuido chega a permitir a reunião de todas as causas capazes de atacar rapidamente o princípio vital, a sociedade em muito pouco tempo é quase toda vítima de seu fatal estrago. De que oxalá não existissem tantos exemplos (SILVA, 2008 p.69).
\end{abstract}

E prossegue analisando o clima, o relevo, os ares, as águas; lugares como cemitérios, lazaretos, hospitais; e ainda algumas práticas sociais, como o manejo de escravos e modos de vida da população. Um trecho que evidencia e rememora o clássico texto de Foucault segue abaixo:

É por consequência de boa polícia o aterrar todos os lugares pantanosos, o encanar às águas para aquelas valas que se julgarem suficientes para o seu despejo, e que devem participar das alternativas da maré; o determinar o lugar, em que se devem edificar as casas, a altura das portas a estrada, para que os particulares concorram com o Estado ao aterro das novas ruas; e tudo o mais que no meio de semelhantes cuidados se julgar necessário para extinguir uma causa tão oposta à nossa boa existência (SILVA, 2008 p.73).

Outra interessante passagem que denota a governamentalidade biopolítica da época é esta: "quantos vassalos de Sua Alteza Real o Príncipe Regente Nosso Senhor 
terão sido sepultados nesta cidade, gozando ainda do princípio de vida e de que o Estado poderia tirar proveito e partido!" (SILVA, 2008 p. 76).

Aproximando-nos mais do nosso objeto de reflexão - o controle e a vigilância de doenças - destacaremos passagens que tocam no que hoje nomeamos "risco sanitário" com alguns rudimentos de regulação:

\begin{abstract}
Entram carnes degeneradas na cidade, e seus donos, mandando-as lavar e secar na outra banda, as introduzem à venda, e aproveitam-se delas as casas, que têm muita escravatura, bem como as lojas de venda, das quais a maior parte lançam de si um péssimo cheiro, sendo ele o melhor denunciante de semelhante fazenda. Acontece o mesmo nos peixes escalados, e na farinha de mandioca, a qual se vende ao público naquele estado de fermentação, a que vulgarmente se chama ardida; talvez seja essa a principal causa das lombrigas nos pretos, e ainda nos brancos pobres, que procuram o mais barato. Tem igual sorte todo o grão que entra na cidade - os trigos estejam em bom ou mau estado são reduzidos a pão (SILVA, 2008 p.78).
\end{abstract}

Deve-se, pois, fazer a indagação necessária sobre os gêneros animais e vegetais antes que se exponham à venda; e os donos não poderão conseguir os despachos para ela, sem que apresentem certidão do seu bom estado, passada por aquele, que para isso estiver autorizado, que deve ser o físicomor do reino, ou o seu delegado (SILVA, 2008 p.79).

Quem entra no matadouro é obrigado a louvar a escolha do local e a maneira em que ele está construído; ali se encontra uma espaçosa casa, cujas paredes são formadas por grades de madeira, que facilitam a livre corrente do ar, tão necessária para os empregados naquele trabalho cujas vidas merecem a contemplação do Estado (SILVA, 2008 p.80-81).

Outra causa capaz de conduzir muita gente à sepultura nesta cidade é a falta de bons medicamentos, em que possa confiar uma medicina ativa; a liberdade concedida a qualquer cirurgião para curar de Medicina, ignorando até os princípios os mais simples da sua profissão; a falta de vigilância sobre os curandeiros e boticários, que vendem purgantes, vomitórios e outras composições sem receita de médico, chegando a omissão nesse ponto de permitir que nas lojas de ferragens se vendam vomitórios e purgas à discrição de cada um que se persuade dever usar deles (SILVA, 2008 p. 82).

Aparecem aí sinais evidentes de um esboço da Vigilância Sanitária tal qual mais tarde tomará forma.

A ode à Higiene enquanto ciência e método a ser instituído urgentemente no Império também se evidencia em um texto de 1820, endereçado à corte, de Domingos Ribeiro dos Guimarães Peixoto - médico - "Cirurgião da Câmara de EL-REI Nosso Senhor"; assim ele se expressa: 


\begin{abstract}
A saúde é, sem contradição, o mais precioso bem que podemos possuir, e para cuja conservação é mister haver boa conduta na aplicação dos agentes necessários à nossa existência; por isso que a perdemos com tanta facilidade, tamanha é a dificuldade que encontramos para a restaurarmos: ela supõe sempre, quando não extintas, ao menos diminuídas em grande número as causas que a deterioram; é ela quem faz a felicidade da nação, conservando a preciosa vida aos soberanos, concorrendo à prosperidade $\mathrm{e}$ aumento das ciências e das artes, do comércio e da agricultura, e mantendo o vigor e a energia dos povos: sem ela o homem é um ente desgraçado e torna-se um objeto de compaixão e horror...(PEIXOTO, 2008 p. 94 ).
\end{abstract}

Tais excertos, riquíssimos a nosso ver, podem ser tomados enquanto evidências iniciais de um projeto biopolítico em formação - fortemente influenciado pela escola médica europeia, nossa fonte inicial de conhecimento médico.

Costa e Rozenfeld (2000) informam que a vigência do Regimento da Provedoria, de 1810, baseado no modelo de polícia médica europeu, e a posterior elaboração do Código de Posturas no Rio de Janeiro, em 1832, são marcos importante para o controle sanitário e para a concretização das mudanças trazidas pela vinda da corte em 1808.

Foi, a rigor, durante a alvorada da República (1889) que os rudimentos de uma política de saúde começaram a tomar forma no país. Exercer o mínimo de controle através de instituições de saúde foi uma estratégia necessária para o surgimento do capitalismo brasileiro - é o que aprendemos com Nilson do Rosário Costa em "Lutas Urbanas e Controle Sanitário":

O objetivo das políticas de saúde pública não foi proteger a totalidade dos habitantes do país dos surtos epidêmicos e doenças parasitárias nem sua finalidade foi recuperar a saúde do comum dos homens. Ao contrário do que sustentavam os tratados sobre o projeto de saúde pública no Brasil, que se limitaram a uma cronologia da aprendizagem progressiva por parte da humanidade de meios idôneos para curar as enfermidades, considera-se que o ritmo, extensão e intensidade das ações sanitárias obedeceram a critérios predominantemente utilitários, definidos a partir dos interesses dos grupos dominantes internos ou pela expansão do capitalismo em escala internacional (COSTA, 1985 p. 12).

Corroborando nossa perspectiva biopolítica, ele ainda arremata:

O discurso regulador e normativo de saúde se apresentou, assim, articulado ao conjunto de mecanismos e técnicas cujo fim último foi obter das classes subalternas uma conduta racional e permeável às iniciativas estatais frente à doença. Os dispositivos sanitários não visaram simplesmente combater os 
preconceitos e a ignorância do público em relação à doença. Sua estratégia compreendeu o esforço de regulamentar, enquadrar, controlar, punir todos os gestos e atitudes, comportamentos, hábitos e discursos de classes subalternas e apropriar-se dos modos e usos do saber estranhos à visão hegemônica do corpo, da saúde e da doença (COSTA, 1985 p. 14).

Essas esclarecedoras citações podem ser lidas na ótica da governamentalidade para o ambiente da expansão cafeeira, da imigração italiana e da interiorização do país. Era tempo de governar definitivamente a população. A Bacteriologia foi um instrumento fundamental para a efetivação das primeiras políticas e, mais ainda, para ignorar aspectos sociais tidos como importantes para o controle de doenças, considerando as possibilidades de eficácia que os conhecimentos parasitológicos e microbiológicos ofereciam. Vacinação, controle de insetos e animais estão entre as principais estratégias biopolíticas do período. Biopolítica que tinha como espírito preservar a força de trabalho no país, em especial na capital e algumas regiões do Estado de São Paulo.

Em 1886, a Reforma de Mamoré criou o Conselho Superior de Saúde Pública, dividindo os serviços sanitários no país em duas frentes: a de Higiene Terrestre e Dos Portos, com ênfase na capital imperial; e dez anos depois, 1896, foi criada a Diretoria Geral de Saúde Pública (DGSP). Aqui o projeto de controle foi ainda mais claro quanto às atribuições, referindo-se a serviços sanitários de portos, fiscalização de exercício de medicina e farmácia, estudos sobre doenças contagiosas, organização de estatísticas sanitárias e auxílio aos Estados em situações de epidemias (HOCHMAM, 2012). Perante a perspectiva foucaultiana que adotamos, tais elementos têm clara tonalidade biopolítica.

A economia cafeeira foi determinante para a criação de necessidades de saúde que importassem ao Estado. Máquinas de beneficiamento e ferrovias estão entre as tecnologias que demandaram a efetivação de uma condição sanitária mínima, sobretudo para a sobrevida dos imigrantes em terras brasileiras. Com o fim da escravidão, em 1888, o Brasil necessitava de mão de obra e teve início um período de intenso fomento à imigração, principalmente vinda da Europa. Entre 1890 e 1900, a população do Brasil aumentou de 14 para 17 milhões de pessoas (COSTA, 1985). 
A economia cafeeira intensificou um clima governamental, uma governamentalidade contra os obstáculos que a situação de saúde impunha. Antes, como vimos, Dom João VI exigira estudos e melhorias para a capital - então, o Rio de Janeiro; no contexto da primeira república, quando São Paulo começa a ter maior relevância para o país, a necessidade de estratégias biopolíticas para lidar com a população era premente.

Em consonância com nosso objeto de estudo, o combate inicial era eminentemente ambiental. Nominalmente, combatia-se a febre amarela, a varíola e a peste, predominantemente nas áreas urbanas e em nome da consolidação da imigração. Os imigrantes, por sua vez, traziam para áreas ainda imunes doenças "novas" como cólera, escarlatina e tifo.

Paiva e Moura (2008), esclarecendo a operação da Hospedaria dos Imigrantes em São Paulo, referindo-se ao mesmo período, informam que nesse local:

\begin{abstract}
Os serviços de alimentação e alojamento eram intercalados com os do controle médico-sanitário, registro e direcionamento ao trabalho. No que se refere aos serviços médicos, valem destaque aos serviços de higiene, nos quais eram realizados procedimentos básicos como banho, desinfecção e troca de roupas, e a inspeção pelo serviço médico, que avaliava com mais acuidade o estado de saúde do imigrante (PAIVA \& MOURA, 2008 p.30).
\end{abstract}

A Vigilância Sanitária de Portos deve ser encarada como um importante foco de controle estatal sobre a população, preocupando-se com os riscos de introdução de epidemias, e gerou, inclusive, um primeiro debate internacional de regulamentação sanitária entre países que estabeleciam relações comerciais. Falhas graves neste sistema comprometeriam tanto a população como o comércio em geral.

O debate entre o paradigma miasmático e a teoria dos germes foi um pano de fundo importante para a emergência de táticas de saúde pública eficientes e responsivas para a época. Quanto à febre amarela, por exemplo, a corroboração do mosquito como vetor foi fundamental para o combate bem sucedido. $O$ posicionamento de Oswaldo Cruz a favor da teoria culicidiana, que defendia a transmissão vetorial, foi crucial; importante destacar que tal adesão foi anterior ao conhecimento do agente etiológico (BENCHIMOL, 2004). 
São desse período a criação do Instituto Bacteriológico em São Paulo, sob a direção de Adolfo Lutz, e de um laboratório para produção de soros e vacinas contra a peste em Santos-SP, sob a direção de Vital Brasil. Em 1892, a participação da rubrica de saúde e saneamento no Estado de São Paulo apresentou a impressionante marca de $46 \%$ em nome da melhoria das condições sanitárias (COSTA, 1985).

Mesmo com a hegemonia bacteriológica do período a perspectiva ambientalista não foi abandonada, tomando o contexto social como uma variável importante para conter o circuito micróbio versus seres humanos (HOCHMAN, 2012).

Para progredir era necessário superar o problema da interdependência, da "doença que pega" - era necessário um Estado interventor, pois algo mais ocorria e alimentava o medo coletivo:

\begin{abstract}
A ideia de consciência social será operacionalizada como consciência de interdependência social, isto é, a percepção das elites quanto à ampliação dos elos de interdependência social, que pode, ou não, ser acompanhada de sua disposição em contribuir com as soluções para as adversidades e deficiências que afetariam potencialmente tanto as elites quanto outros segmentos sociais. Tal disposição estaria condicionada a que as elites se dessem conta da amplitude territorial e da extensão do caráter coercitivo do arranjo necessário à administração dos efeitos da mútua dependência (HOCHMAN, 2012 p.52).
\end{abstract}

Esse também foi o tempo da Polícia Sanitária, das primeiras notificações compulsórias, da vacinação obrigatória contra a varíola, da criação da Inspetoria Geral de Higiene (1890) na cidade do Rio de Janeiro, que exercia vigilância sobre habitações populares e sua localização, locais públicos, alimentação pública, consumo/fabricação de bebidas nacionais, comércio de alimentos, escolas, casas de saúde e maternidades, além de uma atenção especial aos portos. Uma legislação específica sobre os portos foi produzida no governo de Campos Salles, em 1902, disparada por uma importante epidemia de peste, instituindo cartas sanitárias, quarentenas e fiscalizações em navios, entre outras medidas de empoderamento da autoridade sanitária (COSTA, 1985). 
No início do século XX ocorreu uma das mais importantes campanhas sanitárias da saúde pública no Brasil: a campanha contra a febre amarela encabeçada por Oswaldo Cruz. Entre as estratégias aplicadas, algumas ainda lembram as atuais, tais como: visitas domiciliares, eliminação de focos de criadouros de mosquitos com querosene e creolina, limpeza pública visando a eliminação de águas paradas e evidentemente a notificação compulsória sob forte repressão policial aos "sonegadores de doentes". Obviamente, tais medidas autoritárias geraram grande reação popular, particularmente no que tange o adentramento forçado dos espaços domésticos pelos inspetores sanitários. Oswaldo Cruz: o "general-mata-mosquito" (COSTA, 1985).

Foi o nosso tempo de fenômenos semelhantes aos explicitados na medicina das cidades, nos termos de Foucault, em especial ao relatar o caso da França em "O Nascimento da Medicina Social". É, no entanto, fundamental deixar claro a absoluta diferença de contextos e projetos envolvidos, entre essas nações, sua história e economia.

A governamentalidade biopolítica avançava com o estabelecimento das notificações compulsórias de doenças (1902), a saber: tifo, cólera, febre amarela, peste, varíola, difteria, tuberculose e lepra; avançava ainda com o estabelecimento da polícia e da autoridade sanitária, como já citamos; e por fim, medidas como a lei de vacinação obrigatória contra a varíola, lá em 1904 (HOCHMAM, 2012), ajudam a perceber o tom disciplinar e a restrição de liberdades em voga. A ação coercitiva em nome do bem público nas campanhas, de caráter militar, contra a febre amarela e contra a varíola, ilustra essa conclusão.

E, considerando nossa perspectiva foucaultiana, o que pode ser mais interessante que a estratégia biopolítica mais famosa e polêmica registrada em toda nossa história: a vacinação obrigatória contra a varíola? A ira popular foi imensa e o quadro epidemiológico era dramático. Em 1908 a mortalidade por varíola atingiu a marca de 1.212, 45/100.000 no subúrbio da cidade do Rio de Janeiro. Ainda assim, chegou a existir a LIGA CONTRA A VACINA OBRIGATÓRIA, uma organização com expressivo apoio político e popular (COSTA, 1985). 
A ênfase dada às epidemias não eram equilibradas, dado que a visão estatal se pautava em razões, sobretudo pragmáticas. A tuberculose, por exemplo, não teve a visibilidade da peste, da varíola e da febre amarela, apesar da sua importante mortalidade.

\begin{abstract}
Essa atenção desigual dedicada às diferentes causas de mortalidade e morbidade caracterizou a política de saúde pública e tornou evidente que sua ação manteve-se dentro dos limites definidos pelos interesses dominantes da sociedade, que não seriam propriamente os de combater todas as doenças e proteger indistintamente toda a população (COSTA, 1985 p.79).
\end{abstract}

O foco sempre esteve voltando para as doenças epidêmicas.

Outro evento muito marcante foi a gripe espanhola. Esta epidemia de mortalidade avassaladora desnudou as fraquezas da organização sanitária da primeira república. Esse evento foi decisivo para a consolidação de um movimento sanitário no país, disparado pela imensa crise social que as ações de saúde pública denotavam - tanto no que era combatido quanto no que era negligenciado.

Ao atingir também as elites, a epidemia produziu um consenso mínimo sobre a necessidade urgente de mudanças na área da saúde pública. Afinal, todos pareciam ser iguais perante algumas doenças o que certamente aumentou a sensibilidade de muitos parlamentares às propostas de reorganização dos serviços sanitários (HOCHMAM, 2012 p.126).

Foi a descoberta dos sertões e da tríade malária - ancilostomíase - mal de Chagas, uma espécie de segundo grande momento do movimento sanitário do período. O país, para ser uma nação, deveria ser "salvo" agora pelo saneamento do interior. Hochman, citando Miguel Pereira, lembra sua célebre e polêmica frase: "o Brasil é ainda um imenso hospital", referindo-se a tudo que extrapolasse Rio de Janeiro ou São Paulo, as nossas endemias típicas e tão agressivas que faziam o nosso "estrume de povo" (HOCHMAN, 2012).

Comentando outra viagem de exploração ao interior do Brasil em 1917, desta vez empreendida por Souza Araújo aos sertões paranaenses, Gilberto Hochman (2012) destaca:

Para além das condições precárias de vida, da ignorância, dos fatores ambientais - como a derrubada das matas -, dos fatores econômicos - como a cultura "anacrônica do arroz" -, o principal fator que explicaria a situação 
sanitária dos sertões do Paraná, como os de Goiás, seria a "criminosa indiferença" das três esferas do governo em relação ao caráter endêmico da malária (HOCHMAN, 2012 p.69).

A solução para a situação de saúde deveria passar pela fresta da elite, que teria o poder de demandar e viabilizar soluções.

A ciência médica ia se estruturando enquanto instrumento de exercício de poder e governo, buscando "identificar os sintomas de nossa cultura, submetendo-os ao espelho crítico de um outro civilizado, constituindo-se, enfim, em um instrumento do projeto modernizador que garantiria a almejada sintonia com o progresso" (LIMA E HOCHMAN, 2004 p. 495).

Já que era necessário governar um povo com característica nosológica tão marcante, um personagem foi criado para fomentar a propaganda sanitarista: Jeca Tatu - uma caricatura do sertanejo improdutivo brasileiro.

Jeca Tatu, o lendário personagem de Monteiro Lobato, explicita bem a governamentalidade da época. Inicialmente descrito como um fracasso humano e anti-modelo, mais à frente torna-se um novo homem graças à higiene:

\begin{abstract}
A ressureição do Jeca Tatu é narrada na forma de uma parábola dirigida às crianças. Ao passar a acreditar na ciência médica e a seguir suas prescrições, o personagem transforma-se. Livre da opilação e, como consequência, do estado de permanente desânimo, torna-se produtivo e, em pouco tempo, um próspero fazendeiro, competindo com seu vizinho italiano e, rapidamente, ultrapassando-o.... Mais do que isso: modernizou sua propriedade, introduziu novas lavouras e tecnologia e aprendeu a falar inglês. Ao fim da história, um ensinamento moral: Jeca Tatu transformara-se não apenas num homem rico, mas em incansável educador sanitário, que transmitia a seus empregados todos os conhecimentos que aprendera. Morreu muito idoso, sem glórias, mas consciente de que havia cumprido sua missão (LIMA E HOCHMAN, 2004 p.511).
\end{abstract}

Outro tema que dialoga muito com todo o exposto acima é a eugenia, corrente que estimulou e produziu debates sobre a infância, saúde materna, família, controle de doenças e imigração. No Brasil, um país "disgênico" na perspectiva europeia, a primeira sociedade eugênica com fins científicos foi fundada em 1918. Na década de 20, liderado por Renato Kehl, o movimento eugênico estava sendo conclamado a 
eugenizar o país em busca de um aperfeiçoamento racial, já que na Europa o país era considerado degenerado, instável e incapaz de progresso (STEPAN, 2004).

Dentre as personalidades já citadas neste texto, fizeram parte da referida sociedade Belisário Penna e Arthur Neiva, sendo o primeiro autor de obras sobre soluções eugênicas para a degeneração hereditária do povo, uma delas intitulada "Exército e Saneamento". No Rio de Janeiro, em 1929, ocorreu o Primeiro Congresso Brasileiro de Eugenia.

Os temas abordados na conferência foram, de fato, abrangentes: matrimônio e eugenia, educação eugênica, proteção da nacionalidade, tipos raciais, a importância dos arquivos genealógicos, imigração japonesa, campanhas antivenéreas, tóxicos e eugenia, tratamento dos doentes mentais e proteção à infância e à maternidade. Os participantes aprovaram diversas resoluções, a mais controvertida das quais foi a defesa de uma política nacional de imigração que limitasse a entrada no Brasil aos indivíduos julgados 'eugenicamente' adequados com base em algum tipo de avaliação médica (STEPAN, 2004 p.345).

No Brasil, a eugenia, de fortes bases neolamarckianas, tinha um aspecto muito mais social que biológico, e foi tomada por alguns como um novo ramo da higiene "sanear é eugenizar" - não havia uma clara distinção entre natureza e cultura. Interessantíssimo citar a existência de concursos populares que premiavam famílias eugênicas a partir do julgamento de crianças "eugenicamente" belas. Aliás, segundo Nancy Stepan (2004), a popularização da palavra puericultura e a ênfase na saúde materna e infantil são heranças desse movimento (STEPAN, 2004).

Quanto à raça, a rigor, visava-se a diminuição da natalidade entre pobres, negros e mestiços. A meta? Resgatar o Brasil da decadência tropical e da degeneração racial.

Mais à frente, ainda na primeira república, estabeleceu-se no país uma discussão entre mendelianos e lamarckianos em torno da raça brasileira, que enfraqueceria todo o movimento, escancarando uma ideologia racista e negativa por parte de Renato Kehl em contradição com posições mais amenas e "livres" de racismo (mendelianas). Com o passar do tempo o Lamarckismo perde o debate e a discussão 
em torno da raça se torna mais "social", graças à contribuição de autores como Gilberto Freyre.

O objetivo destas breves digressões ao nosso contexto foi apontar momentos onde a elite brasileira deveria optar pelo desenvolvimento de uma população brasileira.

A pressão da intelectualidade sanitária produziu efeitos positivos como a criação do Serviço de Profilaxia Rural em 1918, buscando socorrer as endemias de doença de chagas, malária e uncinariose nas regiões agrárias no país, além de contribuir para uma política de distribuição de medicamentos contra doenças endêmicas e epidêmicas pelo governo, no mesmo ano (COSTA, 1985).

O diagnóstico de Miguel Pereira à formandos da Faculdade de Medicina em 1916, de que "o Brasil era um imenso hospital, mas não um hospício", provocou forte repercussão na elite que sabia da necessidade de melhorias e tinha que responder à demandas sanitárias para garantir sua segurança e bem estar econômico. Alguns consideravam a versão dos sanitaristas exagerada, mas a discordância não foi explicitada, ainda que alguns julgassem que se focar no interior do país era um equívoco. Isso impactou o Congresso Nacional e gerou discussões, ampliando cada vez mais a pauta da saúde no contexto nacional (HOCHMAN, 2012). Problemas relativos ao financiamento de obras (o dilema governo estadual versus governo federal) e a criação de um órgão central nacional de saúde, um ministério, foram debatidos e culminariam na criação deste, mais tarde.

É ainda desta marcante fase a organização da Liga Pró-Saneamento, um movimento de cunho sanitarista que culminou na produção do Departamento Nacional de Saúde Pública em 1920, referido acima. Esse departamento tinha como propósito toda uma biopolítica, "chamemos básica, que consistia em: pesquisas bacteriológicas, fiscalização de alimentos, medicamentos, farmácias, hospitais, saneamento, fiscalização de portos e rios e o serviço demográfico-sanitário" (COSTA, 1985). 
Este Departamento, organizado em uma Diretoria Geral e três diretorias - a de Serviços Sanitários Terrestres, a de Defesa Sanitária Marítima e Fluvial e a de Saneamento e Profilaxia Rural - abrangeria atividades como: serviços de higiene no DF, higiene domiciliária, polícia sanitária de habitações, fábricas, colégios, comércios, hospitais, matadouros, hotéis, lugares públicos, portos, pesquisa científica de doenças transmissíveis, fornecimento de insumos farmacêuticos para combate às epidemias, fornecimento de medicamentos oficiais, exame químico de alimentos nacionais e importados, inspeção médica de imigrantes, estatísticas sanitárias e divulgação de boletins, fiscalização de esgotos, fiscalização de venda de produtos farmacêuticos, do exercício de medicina, farmácia e odontologia e a criação do Código Sanitário Nacional (HOCHMAN, 2012). Este departamento foi considerado a vitória da Liga PróSaneamento do Brasil.

Foi através do Departamento Nacional de Saúde Pública que a legislação sanitária da primeira república foi consolidada, instituindo inclusive a criação da vigilância sanitária, que cuidava desde os serviços citados acima como da notificação compulsória e vacinação, disciplinando e regulando atividades de interesse à saúde pública (COSTA, 1985).

A Fundação Rockfeller, através de sua Repartição Internacional de Saúde Pública, em tempos de importante fluxo de capital americano no país, entra no Brasil nesse período e toma a frente do combate à febre amarela, no Norte, e do controle da ancilostomíase em vários Estados. O modelo de Centro de Saúde, com atendimento regionalizado e participação comunitária, foi um legado da Rockfeller ao país, além da criação de centros de ensino e pesquisa (COSTA, 1985).

De toda forma, parece claro que os primeiros problemas de saúde pública brasileiros estavam relacionados ao ambiente tropical e ainda hoje lidamos com as mesmas questões seguidas de importantes incrementos tóxicos de natureza industrial. Qual seria a governamentalidade presente neste período inicial? Diretamente, como a autodefesa e a centralização do poder sanitário eram instáveis, com o nível federal atuando apenas, ou mais fortemente, em situações epidêmicas, a crise girava em torno da ampliação do poder público sobre o território e sobre o 
problema do custeio, já que a Constituição de 1891 centralizava nos municípios e Estados as ações de saúde.

A quem interessava uma saúde pública eficiente? A todos. Mas quem pagaria por ela, todos? Eis a tensão, diante da divisão justa de papéis e custos frente ao mal público. Foi nesse clima que a reforma sanitária da primeira república foi desenvolvida.

\begin{abstract}
Em pelo menos um caso, o de São Paulo, no período de 1889-1930, prevaleceu uma solução individual para os problemas de ação coletiva. Esta alternativa foi implementada ao longo da primeira república, quando São Paulo desenvolveu largamente seus serviços sanitários, procurando internalizar os custos externos e preservar a autonomia estatal em face da ingerência do poder central. O estado de São Paulo foi praticamente o único capaz de formular uma estratégia sanitária e implementar permanentemente políticas de saúde pública. Com isso, melhorava as condições sanitárias de sua população e território, e diminuía os impactos negativos sobre outras unidades, o que significava um benefício coletivo custeado por São Paulo (HOCHMAN, 2012 p.159).
\end{abstract}

Nesse ínterim, outro fenômeno fundamental foi acontecendo: a formação dos profissionais de saúde pública. De acordo com Hochman (2012), os instrumentos tradicionais eram as palestras e panfletos, além dos cursos populares de higiene e transmissões de conferências via rádio. A Fundação Rockefeller concedeu, na época, cerca de 70 bolsas de estudos na Johns Hopkins University e incentivou a criação do Instituto de Higiene na Faculdade de Medicina de São Paulo.

Interessante notar ainda que em termos ambientais, o debate girava em torno do saneamento e dos vetores - ou seja, a dimensão biológica era o foco. Um pouco mais à frente teria início uma dimensão silenciosa e que por muito tempo assim permaneceria - a toxicológica - com a industrialização e o envenenamento químico da produção na agropecuária.

A seguir, listamos algumas normas no intuito de ilustrar alguns movimentos no controle sanitário brasileiro durante o Estado Novo (COSTA \& ROZENFELD, 2000), para com isso avançarmos mais diretamente ao período de industrialização crítica e seu desenvolvimento silencioso rumo a uma intoxicação ambiental generalizada, uma vez que nesse período a indústria já conhecia um forte desenvolvimento. 
- O Decreto 3.171 de 1941 cria o Serviço Nacional de Fiscalização da Medicina, um importante órgão de produção de legislação sanitária;

- Decreto-Lei 19.606/31 e Decreto 20.377/31 sobre o exercício da farmácia;

- Decreto-Lei 4.113/42 legislando sobre a propaganda dos produtos farmacêuticos e dos profissionais de saúde;

- Decreto 19.604/31 criminalizando a venda de gêneros alimentícios fraudados;

- Decreto 780/36 e Decreto 891/38 sobre entorpecentes;

- Decreto-Lei 7.841/45 que aprovou o Código de Águas Minerais.

Em adição, as mesmas autoras salientam que:

\begin{abstract}
Junto a uma política econômica de incentivo à expansão do grande capital monopolista, ocorreram profundas mudanças de governo e de regime no país, secundadas por alterações na organização sanitária e no plano normativo. Promulgou-se uma nova constituição. Após a queda de Getúlio Vargas, em 1945, seguiu-se um intenso movimento de entrada de capitais estrangeiros, inclusive o da indústria químico-farmacêutica e de alimentos. Houve remessa de lucros para o exterior, sustentada pelo discurso liberal e por um clima político de crescimento de ideais redemocratizantes, acompanhadas de políticas de cunho populista (COSTA \& ROZENFELD, 2000 p.29).
\end{abstract}

O Ministério da Saúde foi criado apenas em 1953 e um Código Nacional de Saúde apareceu apenas em 1961.

\begin{abstract}
Depois de instaurar a ditadura, em 1964, o país passou a ser conduzido sob a égide do binômio desenvolvimento e segurança. Esse período corresponde ao aumento da abrangência do campo de ação da Vigilância Sanitária, com a incorporação de novos objetos e práticas de controle, acompanhando o crescimento da produção e do consumo de produtos e serviços de interesse sanitário. O governo militar promulgou uma nova Constituição e o decreto-lei, instrumento editado pelo Poder Executivo, voltou a ser utilizado como instrumento de regulação, ao invés da lei. Consolidou-se, no final do período, o conceito de vigilância no controle de doenças transmissíveis e o termo Vigilância Sanitária passou a denominar o conjunto de ações nas áreas de portos e fronteiras. Esse conceito se ampliou, na década de 1970, para incluir o controle sanitário de produtos e serviços de interesse à saúde. Nesse período também ocorreu a regulamentação do exercício de várias profissões da área da saúde, através da criação de Conselhos Federais e Regionais (COSTA \& ROZENFELD, 2000 p.31).
\end{abstract}

Com o advento da Ditadura Militar o país entra em um momento de decrescimento de priorização de demandas sociais, o que favorece a demanda pela 
industrialização pouco comprometida com os dilemas sociais em voga, como apontado por Pedro Jacob (1989):

\begin{abstract}
No Brasil pós-64, a posição das políticas sociais no contexto das prioridades governamentais caracteriza-se pela implementação de um novo conceito de eficiência no qual os interesses econômicos prevalecem sobre os interesses sociais. Como reflexo disto, as políticas governamentais nas áreas de bemestar coletivo - saúde, saneamento, educação, habitação e nutrição - têm pequeno destaque na agenda governamental, ou são objetos de formulações de caráter discutível, como é o caso mais explícito da política habitacional e previdenciária. Deste modo, não se altera significativamente o perfil da desigualdade social dominante, o que, somado à compressão salarial e o desemprego, configura um crescente agravamento das condições gerais da população (JACOB, 1989 p.9).
\end{abstract}

Nesse período a política de saúde se caracteriza por privatização e auto sustentação via Previdência Social.

Ainda que em um salto de décadas, cumpre ressaltar a importância da redemocratização e da reforma sanitária culminando na criação do Sistema Único de Saúde, 1988. A visão de saúde abrangente e o enfoque dado aos determinantes sociais dados na Lei 8.080 de 19 de setembro de 1990, permite colocar a temática ambiental em destaque e demandá-la como fundamental para a integralidade do cuidado.

Para reforçar o dito acima, citamos o artigo $3^{\circ}$ que reza os seguintes termos a partir da redação/atualização dada pela Lei 12.864, de 2013:

Os níveis de saúde expressam a organização social e econômica do País, tendo a saúde como determinantes e condicionantes, entre outros, a alimentação, a moradia, o saneamento básico, o meio ambiente, o trabalho, a renda, a educação, a atividade física, o transporte, o lazer e o acesso aos bens e serviços essenciais (BRASIL, 2013).

Além dessa manifestação evidente do papel do meio ambiente no processo saúde-doença, no artigo 6º , inciso V, da Lei 8.080/1990, fica garantida a participação do SUS na proteção ao meio ambiente, nele incluído o do trabalho.

Não detalharemos a história da saúde geral, dado que nossa intenção é demonstrar o movimento biopolítico e a governamentalidade que iam se 
estabelecendo e com isso construir as bases de onde emerge a Vigilância Ambiental. Importa-nos, agora, compreender o desenvolvimento industrial no país e com ele observarmos também o desenvolvimento de uma intoxicação silenciosa. 


\title{
Capítulo 4 \\ Nosso desenvolvimento insustentável
}

Do ângulo da sustentabilidade ambiental, nosso histórico produtivo é exploratório. A começar pelo comércio internacional do pau-brasil, da mineração, outra não foi a vocação dos recursos naturais brasileiros. É curioso notar a presença de atos normativos de controle de bens ambientais, para fins comerciais, entre eles o controle de uso de águas subterrâneas, exploração de recursos minerais e madeireiros, exploração de árvores frutíferas, logo nas primeiras décadas da colonização, sem falar do próprio sistema de sesmarias que dividia e organizava a exploração do território. No entanto, essas normas passaram longe de proteger o meio ambiente colonial e mesmo imperial, uma vez que as diversas tentativas de controle governamental foram sistematicamente frustradas. (CÂMARA, 2013)

O desenvolvimento industrial no Brasil foi sofrido. Seu primeiro impulso apreciável se dá no último decênio do império nos ramos têxtil, alimentícios, químico, madeireiro e metalúrgico, sendo importante sua dispersão pelo território nacional (PRADO JÚNIOR, 1977). Em apenas 15 anos, a população brasileira cresceu 40\%, considerando-se o período entre 1872 e 1900, sendo que mais à frente, entre as décadas de 20 e 40, a população urbana aumentará para mais de 30\% em relação ao período anteriormente citado (SANTOS, 2013). O próprio Milton Santos (2013) solicita cautela ao citar este números uma vez que foi apenas a partir de 1940 que a separação entre população urbana e rural passou a ser devidamente separada, valendo aqui principalmente a contribuição da ideia de aumento muito expressivo.

\begin{abstract}
A Grande Guerra de 1914-1918 dará grande impulso à indústria brasileira. Não somente na importação dos países beligerantes, que eram nossos habituais fornecedores de manufatura, declina e mesmo se interrompe em muitos casos, mas a forte queda do câmbio reduz também consideravelmente a concorrência estrangeira. No primeiro grande censo posterior à guerra, realizado em 1920, os estabelecimentos industriais arrolados somarão 13.336, com 1.815.156 contos de capital e 275.512 operários. Destes estabelecimentos, 5.936 tinham sido fundados no quinquênio 1915-19, o que revela claramente a influência da guerra (PRADO JÚNIOR, 1977 p.261).
\end{abstract}

Em geral, a acumulação de capital no país ocorreu em cenários individuais e dispersos, sem grandes possibilidades de ampliação e com foco no consumo interno; este, sob forte dependência do desempenho do comércio exterior e das contas 
internacionais do país, ora favorecendo, ora prejudicando o desempenho da industrial nacional (PRADO JÚNIOR, 1977).

Segundo Milton Santos:

O Brasil foi, durante muitos séculos, um grande arquipélago, formado por subespaços que evoluíam segundo lógicas próprias, ditadas em grande parte por suas relações com o mundo exterior. Havia, sem dúvida, para cada um desses subespaços, polos dinâmicos internos. Estes, porém, tinham entre si escassa relação, não sendo interdependentes (SANTOS, 2013 p.29).

As indústrias subsidiárias tinham um campo mais sólido, pois utilizavam a estrutura natural, a mão de obra barata e prosseguiam suas explorações de acordo com a conveniência. (PRADO JÚNIOR, 1977).

Como já foi dito, a economia brasileira desenvolve-se em função da exportação, sua gênese é colonial e tem como essência a vulnerabilidade. Essa condição frágil e estrutural foi um dos motivos da fácil penetração do financiamento estrangeiro no país, bem como da sujeição da indústria interna aos seus interesses. A primeira investida internacional se deu no tradicional café, junto com a criação de diversos bancos estrangeiros e outros investimentos em serviços públicos como energia elétrica e estradas de ferro (PRADO JÚNIOR, 1977). Nesse cenário, temos o desenvolvimento industrial e urbano de São Paulo, localizado estrategicamente no caminho para o porto de Santos. O afluxo de imigrantes europeus teve relevante papel no crescimento demográfico, como já vimos, e no estímulo à indústria, mas, ao mesmo tempo, sua condição de despossuídos também limitou o crescimento da economia em virtude de sua parca capacidade de consumo (ARAÚJO, 2008).

A | Grande Guerra dará um primeiro impulso sério à exploração e aproveitamento industrial do minério brasileiro. Um pequena usina instalada desde 1888 em Itabirito (Minas Gerais) produzirá em 1915, 3.259 toneladas de gusa, que se elevarão em 1921 para 15.316. É neste último ano que se instala a primeira grande empresa siderúrgica, a Belga-Mineira, formada de capitais franco-belgo-luxemburgueses, que estabelece sua primeira usina com alto forno em Sabará (Minas Gerais). Outras, mas de menor importância, aparecem em seguida. Empregarão todas como combustível o carvão de lenha obtido localmente (trata-se de uma região de florestas) e uma pequena parte de coque importado. A siderurgia brasileira começa então a se desenvolver, embora ainda muito lentamente. Em 1931, a produção total era apenas de 71.000 toneladas de aço, ferro, gusa, laminados, trefilados e peças fundidas (PRADO JÚNIOR, 1977 p.269). 
Câmara (2013) assevera que do Descobrimento até a década de 1930:

...a governança ambiental pautou-se em normas nacionais emanadas pelo governo central que tinham cunho punitivo, com ações de comando e controle voltadas 'para assegurar a produtividade e o desenvolvimento econômico, e com pouca atenção ao uso sustentável ou de longo prazo dos recursos naturais. (CÂMARA, 2013 p. 129)

A crise de 1930, reflexo do crack de 1929, favoreceu a industrialização em função da enorme desvalorização cambial, aumentando a demanda de produtos brasileiros - o denominado processo de substituição das importações - e, paradoxalmente, à medida que a indústria crescia, aumentava sua necessidade de importação de bens para incremento tecnológico (ARAÚJO, 2008).

Fruto de uma governamentalidade que articulava economia e necessidades básicas de saúde pública, a regulamentação da força de trabalho foi um importante passo para todo este panorama de desenvolvimento, através do Decreto ํㅜ 19.770 de 19 de março de 1931 - que dispunha sobre as regras de organização sindical de patrões e empregados (ARAÚJO, 2008).

Inicialmente expressivo no cenário mundial foram os fornecimentos de borracha, manganês e minério de ferro (todos explorados por empresas norteamericanas); a partir de 1934 o algodão voltou a ter importância no mercado internacional, em especial para o Japão que estabelece uma estratégia de imigração com esse mercado (PRADO JÚNIOR, 1977).

Em 1941 o Estado Novo funda a Companhia Siderúrgica Nacional (CSN) em função de um contexto de grande demanda de aço no país. Ainda no segundo governo Vargas foram iniciadas as atividades da Companhia Vale do Rio Doce (1942), Companhia Nacional de Álcalis e Petrobrás. Entre 1945 e 1958 a produção industrial química, metalúrgica e de material elétrico subiu de $22 \%$ para $38 \%$. Já a participação da indústria de minerais não metálicos, papel, papelão e borracha cresceu de 8\% para 10\% (ARAÚJO, 2008). Em suma, mais devastação, mais desmatamento, mais lixo, mais produtos tóxicos e... desenvolvimento. No período de Juscelino Kubitschek, foi 
a vez do desenvolvimento de uma cadeia de indústria automobilística potente, influente até a atualidade.

Após a II Grande Guerra ocorre um forte crescimento demográfico, fruto de uma natalidade elevada e de uma mortalidade em descenso - já em função, em grande medida, das políticas de saúde mencionadas acima. Aos poucos o território se mecaniza; em função das políticas econômicas em andamento, a nação vai se tornando mais fluida, mais técnico-científico-informacional, com mais fluxos (SANTOS, 2013).

De acordo com Alvarez (2007):

\begin{abstract}
A política industrial brasileira, a partir dos anos 1950, estimulou a absorção de capital e tecnologia estrangeira, com base em incentivos tributários e fiscais, de modo a atrair empresas transnacionais, bem como a associação do capital privado nacional com grupos estrangeiros. O Estado também se tornou investidor direto, fomentando a produção por meio da criação de inúmeras empresas estatais, em geral do setor de base, cujos investimentos iniciais são elevados. (ALVAREZ, 2007 p.268)
\end{abstract}

Após o golpe militar, a partir de 1964, o crescimento da indústria chegou à média de 14\% ao ano (1970 a 1973). No mesmo período, com a ampliação do crédito ao consumidor, o setor de bens de consumo duráveis chegou a cifra de $25 \%$ de expansão. Em relação ao petróleo teve início a prospecção de plataformas marítimas e foi inaugurado o Proálcool (Programa do Álcool); ainda no campo energético, destacam-se o programa nuclear e o início das obras de Itaipu e Tucuruí (ARAÚJO, 2008).

A técnica e a lógica imanente do capital passam a ordenar o território brasileiro e seus lugares; a interdependência, ao contrário dos primeiros séculos, aumenta - e uma polarização vai se estabelecendo: locais com grande conteúdo de saber técnico e os locais ainda não dominados por essa lógica, locais do fazer (SANTOS, 2013). Fundamental reforçar que durante todo esse movimento houve aumento da dívida externa e cada vez maior dependência de capital estrangeiro.

As cidades se tornam técnicas, precisam de agrônomos, professores, promotores, engenheiros, médicos, e a população consome saúde, educação, junto 
com equipamentos elétricos e televisões. Estas localidades exigem cada vez mais energia. Firmas hegemônicas têm influência sobre o Estado e mudam as regras da economia e da sociedade à sua imagem (SANTOS, 2013).

Para reforçar o ambiente político da época, citamos novamente Alvarez (2007), que ao refletir sobre Gonçalves (2001) coloca que:

\begin{abstract}
Se na década de 1970, o governo brasileiro criou uma série de instituições para gerir os problemas ambientais, ele o fez para atrais mais recursos estrangeiros, uma vez que as agências e instituições financeiras internacionais começaram a fazer determinadas exigências para liberação de créditos, entre as quais a criação de medidas relativas ao meio ambiente. (ALVAREZ, 2007 P. 266)
\end{abstract}

Na década de 80 , a taxa de urbanização da população brasileira passa de $26,35 \%$, em 1940 , para $68,86 \%$. Sintomaticamente, o consumo de agrotóxicos passa de 27,7 toneladas em 1970 para mais de 125.000 toneladas em 1984 (SANTOS, 2013). O envenenamento dos alimentos, através de técnicas grosseiras de aplicação, se tornou banalidade fundamental, indispensável para alimentar a todos.

O desenvolvimento industrial nunca foi autônomo, mas sempre controlado pela lógica da política financeira internacional. Obviamente, os mecanismos biopolíticos que descrevemos acima não visavam senão preparar o terreno para uma exploração econômica vampira, que em nenhum momento dialogou com as necessidades internas do país (PRADO JÚNIOR, 1977). Esta parasitologia econômica e ecológica foi bem expressa na expressão "veias abertas da América Latina" de Eduardo Galeano. Terra de uso. Descartável em natureza e população.

Após a milagre econômico brasileiro, que ofereceu crescimentos econômicos de até $7 \%$ ao ano pelo PIB, em meados do final de 1970, sequencialmente a redemocratização, o Brasil vai assumir uma agenda neoliberal que será tocada à todo vapor - em especial no governo de Fernando Henrique Cardoso, mas sem deixar de seguir em frente nos governos de Luís Inácio Lula da Silva e Dilma Rousseff. O ponto essencial dessa agenda, em consonância com o famoso consenso de Washington, era reduzir gastos públicos, manter juros e câmbios balizados no mercado, 
desregulamentação trabalhista e privatização de empresas estatais, entre outras medidas (OLIVEIRA, 2015).

Exatamente aqui cabe uma breve parada para constatar que estamos em plena governamentalidade neoliberal, como já mencionamos ao tratar das ideias de Foucault. Desenvolvimento é a palavra que designa na prática estado mínimo e a economia de mercado em instalação. Vale destacar que neste ponto nossos principais passivos ambientais já haviam há muito ocorrido, uma vez que a Política Nacional de Meio Ambiente foi publicada apenas em 1981, e as parcas de regulamentação não apresentaram efeito expressivo, sendo apenas formal.

Em função de tudo isso, cumpre destacar o fenômeno do Estado-corporação. Luiz Marques lembra que:

\begin{abstract}
Ao longo do século $X X$, as relações de complementaridade entre os Estados nacionais e as corporações generalizam-se, aprofundam-se e adquiriram, a partir de finais do século, formas suficientemente típicas para justificar a hipótese de uma nova fase do Capitalismo de Estado ou mesmo, como aqui se sugere, de uma verdadeira mudança na natureza do Estado, com a emergência do que poderia chamar o Estado-Corporação, um novo modelo de simbiose entre Estado e Corporação. Esse novo modelo é a grande novidade trazida pela conversão ao capitalismo por parte da China, da exUnião Soviética e dos países da Europa do Leste, mas também pela alavancagem estatal das economias dos 'tigres asiáticos' e de países menos industrializados, como a Índia e o Brasil (MARQUES, 2016 p.34).
\end{abstract}

Ou ainda:

O Estado contemporâneo não representa mais o capital porque representar supõe uma relação entre duas instâncias distintas, ao passo que o que ocorre hoje é um continuum entre ambos. Seria hoje frequentemente mais correto substituir a expressão rede corporativa por estatal-corporativa (MARQUES, 2016 p.37).

Atualizando o exposto com dados recentes, de acordo com a Confederação Nacional da Indústria, em 2015 a participação segundo o PIB industrial do Estado de São Paulo, considerando os principais setores, foi: construção com $23,8 \%$, alimentos com $10,4 \%$, derivados de petróleo e biocombustíveis com 7,9\%, veículos automotores com $7,6 \%$ e químicos com 6,5\%. Observando os mesmos critérios para o Estado da Bahia vemos: construção com 40,3\%, derivados de petróleos e biocombustíveis com $13,8 \%$, serviços industriais de utilidade pública com 12,0\%, químicos com $7,9 \%$ e alimentos com 3,4\%. No Pará, o mesmo contexto de pesquisa apresenta a seguinte 
composição: extração de minerais metálicos com $44,4 \%$, construção com $28,8 \%$, serviços industriais de utilidade pública com 9,5\%, alimentos com 5,2\% e metalurgia com 4,3\% (CONFEDERAÇÃO NACIONAL DA INDÚSTRIA, 2017).

Com os números acima é fácil notar a variabilidade da atividade industrial e seu impacto financeiro e ambiental, tomando apenas alguns Estados como exemplo. A figura abaixo (Figura 1) mostra em números absolutos o tamanho da diferença do porte industrial de cada Estado. Tal visão é importante tanto na perspectiva de controle ambiental quanto da Vigilância em Saúde Ambiental de cada ente federado, que estão sujeitos a riscos de magnitudes muito diferentes a depender da realidade de cada território.

Figura 1 - Número absoluto de estabelecimentos industriais segundo Estado da Federação, Brasil, 2015.

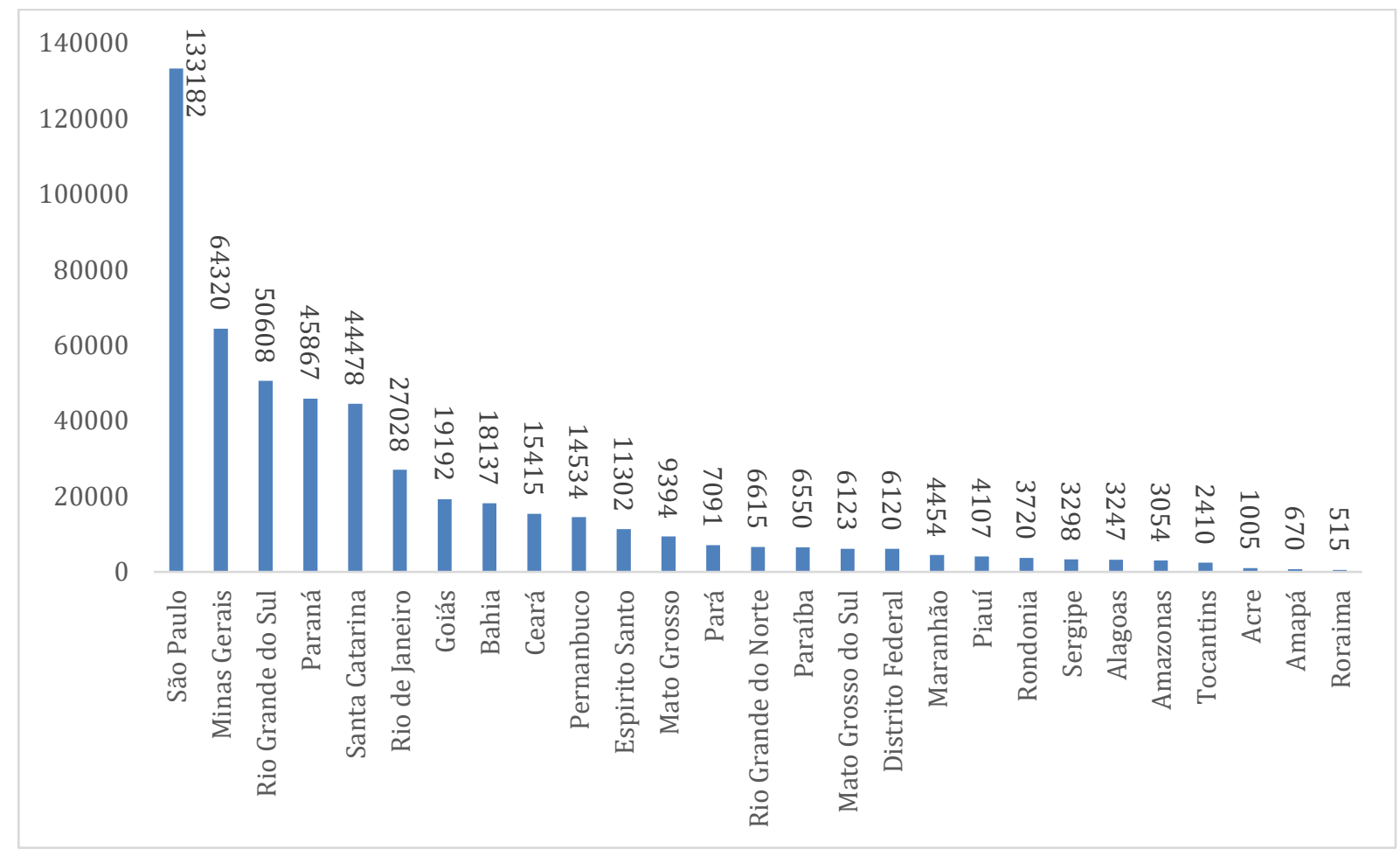

Fonte: Portal da Industria. Disponível em: http://perfilestados.portaldaindustria.com.br/comparativo estados/populares, acessado em 03.10.2017.

Decorre do exposto acima que, especialmente na perspectiva econômica, houve significativo desenvolvimento e com ele necessidades de saúde mais urgentes e específicas, em especial no que tange à conservação de uma população 
minimamente saudável e explorável, como pudemos observar na descrição do desenvolvimento da saúde pública em capítulo anterior. No entanto, em paralelo, foi produzido um cenário fora das lentes estatais - o da poluição ambiental maciça e silenciosa - em pleno andamento e invisível ao Estado, que enxergava apenas o saneamento e as grandes epidemias.

Em suma, mercado, políticas e desinformação fizeram parte de uma estratégia eficiente e desigual. Destacamos que no quesito desinformação, empresas e Estado colaboraram igualmente para tal fenômeno que "naturaliza" a toxicidade a que estão expostas diversas parcelas da população, "naturalizando" a soberania da lógica de mercado sobre a vida como algo inevitável. 


\subsection{Sobre os passivos que herdamos e/ou ainda produzimos}

Neste momento do trabalho relataremos algumas situações que explicitam os impactos ambientais na saúde humana em função dos fatores abordados até aqui. Daremos uma ênfase maior àquelas de cunho físico-químico, ou biogeoquímico, uma vez que é para elas que a área que estudamos terminou estruturada.

Rumo, portanto, à fundamentação de uma genealogia da Vigilância em Saúde Ambiental, tomemos as combinações que são fundamentais para a problemática ambiental em geral: populações imensas governadas sob a lógica do mercado, passivos ambientais tóxicos e o colapso dos ecossistemas naturais, fornecedores de matéria-prima, sob a pressão de uma sociedade de consumo.

A combinação acima tem lugar sob uma governamentalidade neoliberal que veio se estruturando lentamente, abordada por Foucault em "O Nascimento da Biopolítica". Esse "meio ambiente" econômico dá a tonalidade mercadológica e dominante do neoliberalismo: pouco controle e muita liberdade à "mão invisível do mercado". Há quem defenda essa visão supondo que essa "mão" daria conta de conter abusos contra os sistemas naturais, uma vez que o próprio sistema seria prejudicado; há também quem defenda que é possível harmonizar demanda econômica e ritmos ecológicos, trabalhando com a noção de sustentabilidade. Mais à frente citaremos marcos dessas visões, aliás, muito utilizados em históricos relacionando saúde e meio ambiente.

Eis um ponto essencial desta tese: para nós o meio ambiente econômico e social é o modelador dos efeitos sobre a vida em geral - em especial para as populações humanas no caso da Vigilância em Saúde Ambiental, que emerge dentro do Sistema Único de Saúde. Por isso, a nossa visão de meio ambiente, do ambiental, está diretamente relacionada à governamentalidade. Essa, por sua vez, é responsável pela biopolítica que temos hoje.

Ao optar por uma lógica de governar neoliberal iniciamos um tipo de biopolítica que, no sentido mais originário observado em Foucault, tem como lema: fazer viver e deixar morrer. A governamentalidade atual permite as duas coisas. Como? O Estado 
mata? Mata. Basta tomar como ação intencional o deixar, o não agir, o ignorar, o protelar. Defender a diferença entre "deixar morrer" e "fazer morrer" não oferece efeito prático, uma vez que tomamos o "não agir" como uma intenção. Novamente, no entanto, devemos discutir melhor: como isso ocorre?

Em busca de evidenciar o "deixar morrer", olhemos compartimento ambiental por compartimento.

Iniciamos com um primeiro exercício, realizado em 28 de junho de 2017. Foi processada a busca dos seguintes termos no PUBMED (US National Library of Medicine National Institutes of Health), um importante site de pesquisa para o campo da saúde com abrangência internacional: "air pollution health" - "contaminated soil health" e "water pollution health". O resultado numérico total absoluto para artigos publicados foi o seguinte:

- Para "air pollution health": 29.927;

- Para "contaminated soil health": 134.538;

- Para "water pollution health": 10.607.

Quando acrescentado o termo "Brazil" aos termos de cada busca obtivemos, respectivamente: 327, 1943 e 215 na data citada. O número de estudos produzidos é expressivo. Para o ar a busca continha estudos de 1931 até 2017; para o solo, de 1928 a 2017 - e para a água a abrangência foi de 1884 à 2017. Obviamente, para todos os casos o maior número de estudos concentra-se nas últimas décadas. $\mathrm{O}$ volume de estudos encontrados, de toda forma, é expressivo.

Os compartimentos ambientais são em geral separados didaticamente, mas em hipótese alguma são separados ambientalmente - visto que a dinâmica entre eles é intrínseca, o que implica dizer que, genericamente, a contaminação inicial ou predominante de um compartimento termina necessariamente interagindo com os demais. 
Qual o resultado, nos mesmos termos da pesquisa acima, para as palavras "policy pollution health"? Obtivemos 3.685 estudos para o período de 1939 à 2017.

Discutiremos uma parte da produção acima no que tange aos efeitos clássicos das diversas contaminações sobre a saúde humana.

Para o ar são bem conhecidos os problemas respiratórios em geral, afetando sobremodo crianças e idosos, os problemas cardiovasculares e os efeitos sobre o desenvolvimento fetal, como o baixo peso ao nascer e prematuridade. Além das fontes fixas de poluição, como as emissões industriais, por exemplo, a contribuição das fontes móveis, muito especialmente a frota veicular, só aumentou nos últimos anos sendo a mais importante em regiões metropolitanas em todo o mundo. As queimadas são também fontes de emissão especiais e relevantes em muitas regiões no Brasil.

Em recente revisão bibliográfica, Dapper, Sporh e Zanini (2016), em uma pesquisa sistemática para o Estado de São Paulo, as autoras observaram que:

Todas as pesquisas encontradas sugerem que existe associação da poluição atmosférica com problemas das populações estudadas. Dentre os principais trabalhos desenvolvidos, há diversidade de doenças estudadas, demonstrando que a poluição do ar não afeta apenas o sistema respiratório, mas pode ser causador de risco para outros problemas como baixo peso ao nascer, incidência e mortalidade por câncer, partos prematuros e anemia falciforme (DAPPER, SPORH \& ZANINI, 2016 p.96).

É amplamente conhecido, também nesse quesito, o caso de Cubatão/SP. Alvarez (2007) lembra que na cidade:

Em 1984 eram lançados diariamente na atmosfera cerca de 30 mil toneladas de poluentes químicos. Os braços da serra do Mar que circundavam o estuário do rio Cubatão, de modo a formar uma quase-ferradura, dificultam a dispersão dos poluentes, especialmente nos meses de inverno, ocasionando deposição e concentração de material tóxico e inalável e de partículas em suspensão. Uma vez que nos processos industriais não havia controle de qualidade e segurança ambiental, e que a maior parte dos bairros localizavase muito próxima das principais empresas poluentes, a contínua convivência da população com os resíduos emitidos pelas industrias começou a produzir um elevado número de doenças respiratórias e congênitas, aumentando os índices de mortalidade infantil. (ALVAREZ, 2007 P. 271-272) 
A contaminação de solos tem um forte histórico e está relacionada a problemas de manejo e controle de produtos e subprodutos industriais, seja na produção, seja no uso e ainda no descarte, originando o problema dos resíduos sólidos que tem se mostrado crítico em todo o planeta. Por fim, os agrotóxicos são muito citados em situações dessa natureza e terminam por contaminar os alimentos que consumimos - fechando um ciclo de exposição que, em muitos casos, não passa de uma "imposição" para lembrarmos o que verificamos em Breilh (2013).

Rodrigues et al (2011) relata que de 2004 a 2010 o Ministério da Saúde registra, no seu sistema de informação, 5995 áreas contaminadas cadastradas no país, com a estimativa de 12.037.318 milhões de pessoas expostas aos mais diversos contextos - tais como deposição de produtos agrícolas, deposição de resíduos industriais, deposição de resíduos urbanos, acidentes com produtos perigosos e postos de combustíveis.

Já a água é uma espécie de ponto culminante das contaminações acima. Tanto reservatórios superficiais quanto subterrâneos sofrem o efeito do "des" controle ambiental em indústrias, para não falar no clássico problema do saneamento básico. Nesse sentido, a água é "riquíssima" em contaminantes variados, a depender da dinâmica territorial em foco. Desde os clássicos coliformes fecais até as rebuscadas moléculas farmacêuticas hormonais e antibióticos, por exemplo.

Para mais um relevante exemplo, um estudo de 1985 realizado com peixes da Represa Billings já caracterizava o tamanho do passivo ambiental instalado na região metropolitana de São Paulo, mais especificamente em São Bernardo do Campo (SP). Os autores relatam a presença de metais como cádmio, chumbo, cobre e mercúrio, colocando em sério risco a qualidade do pescado da represa, contaminado segundo as normas da época, e demonstrando a incerteza de uma qualidade da água que ainda hoje abastece milhões de pessoas na região. A poluição doméstica e industrial foi relatada como um fator agravante para o contexto estudado (ROCHA, PEREIRA \& PÁDUA, 1985). 
No Brasil temos todos os tipos de problemas relacionados à água. Destaco aqui um estudo de revisão de 343 artigos realizado por Pontelli, Nunes e Oliveira (2016), observando a associação que a maioria dos estudos estabeleceram entre disruptores endócrinos como bisfenol, ftalatos, estrogênios e agrotóxicos e obesidade em várias partes do mundo.

Há ainda a forte dimensão biológica do problema que se dá pela sinantropia. Na primeira revisão histórica que empreendemos mais atrás foi possível observar o problema dos vetores e das terríveis epidemias que estes traziam para as populações em conjugação com as questões urbanas. Ainda hoje a ênfase dada às doenças epidêmicas e aos vetores é imensa, citando o tríplice problema que o Aedes aegypti traz com a transmissão dos vírus da dengue, Zika e Chikungunya, para não falar da malária e da febre amarela, da febre maculosa e da leishmaniose, todas doenças vetoriais.

O Brasil, em função da sua geografia, é muito rico em arboviroses variadas. Algumas já em plena endemia, como as citadas acima, enquanto outras com potencial de explosão a depender do desequilíbrio ecológico que pode ser desencadeado. Falamos dos Flavivirus e doenças como dengue, encefalite do oeste do Nilo, vírus Rocio, encefalite de Saint Louis, Cassipacore, Ilheus, Bussuquara, Iguape; dos togavírus e doenças causadas pelo vírus Mayaro, a encefalite equina do Leste e ainda o vírus Oropouche. Todos em geral responsáveis por doenças febris e neurológicas (LOPES, NOZAWA \& LINHARES, 2014).

Algumas doenças são muito marcadas pelo viés ambiental - e entre elas merece destaque o câncer. Em geral, células se tornam cancerosas por mutações que alteram os genes que controlam o crescimento e a reprodução celular. Entre os contaminantes ambientais encontramos diversos mutagênicos, como a fumaça do cigarro, certos vírus e alguns tipos de radiações. Ambientes de trabalho e dieta estão ainda entre os fatores que podem disparar a oncogênese no organismo, mas julgamos pertinente destacar que o aumento de doenças e mortes relacionadas ao câncer não se deve apenas ao prolongamento da expectativa de vida. A modernidade dispõe de situações de exposição ambiental complexas o suficiente para assegurar isso 
(KORMONDY \& BROWN, 2002). Apenas como exemplo, o benzeno, substância cancerígena, está amplamente distribuída em diversos compartimentos ambientais e sendo emitido o tempo todo por veículos automotores movidos à gasolina. Um exemplo ainda mais marcante é a classificação da poluição do ar como agente cancerígeno, pela Lista Nacional de Agentes Cancerígenos para Humanos (BRASIL, 2014).

O problema do uso dos agrotóxicos no Brasil já é tema clássico nas áreas de saúde e meio ambiente. A abrangência dos impactos é notável. Relacionados a efeitos cancerígenos, mutagênicos, teratogênicos e genotóxicos, seus usos indiscriminados vêm contaminando todos os compartimentos ambientais citados até aqui - além de alimentos e, por decorrência, o leite materno. A Associação Brasileira de Saúde Coletiva (ABRASCO) vem publicando um dossiê de suma importância para a saúde pública no país, denunciando uma situação de multiexposição grave e ocultada por informações deturpadas. Na década de 70 o uso de agrotóxicos no Brasil chegou a ser obrigatório pelo governo para liberação de crédito rural. Hoje o país chega a consumir 1 bilhão de litros de agrotóxicos por ano e temos uma indústria capturada pelo comércio internacional, que prioriza a superprodução e superexploração de commodities para o mercado mundial (ABRASCO, 2015).

Em tudo isso o espírito da governamentalidade neoliberal molda as condições ao permitir que o lucro prevaleça como critério econômico - e, com isso, permite que mecanismos de controle e segurança sejam considerados opcionais e secundários, com toda a obviedade que a lógica econômica pede.

Há ainda o problema da justiça ambiental a rondar cada um dos efeitos que discutimos ao longo das últimas páginas. Um estudo realizado por Acselrad e colaboradores (2009), publicado pela Fundação SEADE em São Paulo, intitulado "Condições e determinantes do acesso da população mais pobre de São Paulo a Serviços públicos" publicado em 2006, mostra que:

O grau de risco mais elevado entre os mais pobres e residentes em áreas periféricas evidencia significativas diferenças entre os domicílios segundo a faixa de proximidade de cursos d'água, principalmente para aqueles localizados à beira de córregos (menos de vinte metros de distância). Os 
moradores próximos de cursos d'água são mais pobres, menos escolarizados, com menos acesso a serviços públicos e bens duráveis, residem em domicílios mais precários do ponto de vista construtivo e estão mais expostos a vetores de doenças transmissíveis, assim como têm mais frequentemente seus domicílios localizados em favelas. Nessas áreas, além da característica natural do risco ambiental, a ausência de urbanização, com falta de rede de esgoto, coleta de lixo etc., torna a população residente extremamente vulnerável (ACSELRAD et al, 2009 p.63).

Rigotto e Augusto (2007) formulam que:

Quando os problemas ambientais são causados por fontes locais, frequentemente suas proximidades são habitadas por grupos sociais mais pobres, enquanto os mais ricos ocupam áreas menos degradadas. À insuficiência de serviços básicos de saneamento, de coleta e destinação do lixo e condições precárias de moradia, tradicionalmente relacionadas à pobreza e ao subdesenvolvimento, somam-se a poluição química e física do ar, da água e da terra, provocando uma vasta gama de doenças e deformações congênitas. (RIGOTTO e AUGUSTO, 2007 p. 477)

De acordo ainda com Acselrad (2009), "configura-se uma lógica entre acumulação de riqueza e a contaminação do ambiente: certos capitais lucram com a transferência dos males ambientais para os mais desprotegidos" (ACSELRAD et al, 2009). Leff (2009) generaliza a assertiva precedente ao dizer:

A dinâmica econômica gerou um progressivo processo de degradação ambiental, acompanhado duma distribuição social desigual dos custos ecológicos. Se, numa perspectiva social, o processo econômico suscita um conflito entre crescimento e distribuição, na perspectiva ambiental aparece como uma contradição entre conservação e desenvolvimento (LEFF, 2009 p.33).

Boulos (2015) nota essa relação na produção de lutas por moradia empreendida pelo Movimento dos Trabalhadores Sem Teto (MTST), ao distinguir que a produção da periferia é pensada sob duas perspectivas: afastar os pobres e, nos grandes espaços vazios deixados entre o centro e as periferias, realizar especulação imobiliária a partir de benefícios que, aos poucos, vão sendo levados aos mais pobres e passam por estas áreas. Assim, o afastamento é cada vez mais garantido e o Estado figura como um agente importante nesta política, bem como promotor de transferências de tecnologias obsoletas e poluentes para essas áreas (BOULOS, 2015).

Ressaltamos com Acselrad (2009) o que em geral ocorre do ponto de vista empresarial quanto à injustiças ambientais com foco em resíduos tóxicos: 
desresponsabilização das próprias empresas com relação aos despejos clandestinos; alegação de desconhecimento da potência tóxica de resíduos; proposta de abertura de negócios para empresas que oferecem "tecnologia limpa"; preferência por pagar multas ao invés de mudar práticas de gestão de resíduos; invisibilização de materiais através de incêndios noturnos; criação de empresas terceirizadas para não responsabilização da empresa "mãe"; tentativa de cooptação pela oferta de serviços sociais não oferecidos adequadamente pelo Estado e, possivelmente acima de tudo, produção sistemática de desinformação.

No caso brasileiro, as estruturas institucionais de avaliação de impactos
ambientais e de licenciamento de atividades se voltam em grande parte para
a legitimação dos empreendimentos. Isso se dá em razão da natureza
limitada e tecnicista da informação produzida, da assimetria no acesso à
informação, da desconsideração do tempo histórico de escuta da sociedade,
do tempo de maturação das informações entre os atores sociais. Os
movimentos sociais são, com frequência, críticos das audiências públicas
burocráticas e manipuladas do papel dos conselhos na sanção cega dos
projetos, assim como dos Termos de Ajustamento de Conduta, quando
usados como instrumento de legitimação da transgressão - ou do
entendimento direto e não mediado pela esfera política entre empresas e
atingidos (ACSELRAD et al, 2009 p.119).

E a explicação para isso segue:

Concretamente, fazendo uso de sua enorme liberdade de se localizar e deslocalizar, as grandes corporações procuram, de um só golpe, desmontar - aparato regulatório social, urbano e ambiental, e enfraquecer as resistências dos movimentos sociais. Ali onde os governos locais cedem, as grandes corporações obtêm as condições institucionais e socioambientais que mais Ihes favorecem; onde os governos locais não cedem, criam-se, pelo déficit de investimento, condições para o enfraquecimento da organização da sociedade e da capacidade regulatória dos governos, de modo que ali também se prepare um futuro mais hospitaleiro para as corporações. A tão bem falada "competição" cuida de fazer com que as condições sociais e ambientais médias do território sejam suficientemente desreguladas para liberar os empreendimentos de qualquer compromisso social ou com a preservação do meio ambiente, além da retórica da "responsabilidade social e ambiental", que dá às próprias corporações o protagonismo na manipulação de suas imagens públicas (ACSELRAD et al, 2009 p. 137).

Tudo isso se agrava quando o desempenho do PIB no contexto mundial é ruim. A partir de informações obtidas em Capitalismo e Colapso Ambiental (MARQUES, 2016), temos que o crescimento médio do PIB real (descontada a inflação) caiu de $5 \%$ entre 1970-1973 para 1,5\% no período de 2008-2011. Não temos dúvidas acerca da implicação ambiental desse fenômeno como um enorme aumento de entropia na 
economia e no meio ambiente. Daí um sintoma sutil e perigoso, dado que o capitalismo é um sistema expansivo e, portanto, ambientalmente destrutivo: a criação de uma auto narrativa tranquilizante e desmobilizante para a agenda ambiental, em tempos de mitigação e não de precaução, necessariamente.

Afinal, o consumo é "santo" e fundamental para o sistema capitalista. Juntos com Leonard (2011), lembremos dois macetes claros do mercado: a obsolescência programada e a publicidade. Ambas, em conjunto, produzem a necessidade de consumo e criam necessidades de maneira cada vez mais invasiva. A autora relata um exemplo emblemático: "quando atravessei a fronteira do Paquistão com a Índia, passei sob um pórtico em que se lia: Bem-vindo à Índia - Beba Pepsi”.

O exposto não esgota a questão, mas com isso propomos clarear a "imposição" ambiental a que estamos submetidos pela governamentalidade neoliberal e julgamos ter elucidado os mecanismos de uma biopolítica contemporânea no polo que culmina em "deixar morrer". Cabe agora demarcar melhor os marcos e os traços de uma genealogia para a Vigilância Ambiental, apontando acontecimentos e eventos chaves que ocorreram, na sua maior parte, durante as décadas que acabamos de relatar durante o desenvolvimento de nosso parque industrial. 


\section{Capítulo 5 \\ O surgimento da Vigilância em Saúde Ambiental: demonstrando uma genealogia}

Chegamos ao ponto central da presente pesquisa: com as interpretações históricas que desenvolvemos aliando saúde e desenvolvimento industrial capitalista, por meio das chaves foucaultianas adotadas, é hora de construir uma genealogia da área denominada Vigilância Ambiental.

Cabe destacar um primeiro momento importante da história da relação saúde e meio ambiente a partir da estruturação da lógica estabelecida por Hipócrates em seu texto Sobre os Ares, as Águas e os Lugares, do século V A.C. Nesta obra, de acordo com Ribeiro (2004), fatores como geografia do local, clima, vegetação e hidrografia já eram relacionadas às doenças de populações gregas, havendo inclusive inspeções de drenagem pública e fornecimento de água já neste período. O sentido científico e ético estabelecido neste trabalho perdura até hoje e ainda é relevante destacar que alguns autores chamaram o período que abordamos páginas atrás como o nascimento da medicina social de Foucault de novo-Hipocratismo (RIBEIRO, 2004).

Como vimos, no princípio não havia micróbios e espécies químicas. Haviam apenas o ambiente e seus humores, odores e miasmas. Havia um projeto de nação em andamento no Brasil e uma população a ser construída e governada. Nesse sentido, apontamos as primeiras estratégias biopolíticas adotadas durante parte do império e na primeira república. O problema do caboclo sertanejo, a solução da imigração, a criação de um mercado interno e o fortalecimento das exportações - e mesmo um pouco antes, a abolição do sistema escravista - deram a tonalidade da biopolítica em processamento no território brasileiro.

A governamentalidade tinha uma missão clara: desenvolver um país, criar uma população economicamente ativa e saudável ou, pelo menos, minimamente saudável para o desempenho esperado. Daí as primeiras ações de saúde pública contra a varíola, febre amarela, peste e outras, sempre objetivando a viabilização de ações de proteção à saúde da população. 
A ênfase era epidêmica e biológica - como já destacamos, a preocupação era com a "doença que pega", segundo Hochman (2012). Com isso propomos que o primeiro momento do desenvolvimento da agenda ambiental foi biológico, com focos nos vetores, no saneamento e mais à frente nos micróbios de transmissão hídrica, vetorial e respiratória. Tal agenda estava conectada à governamentalidade de desenvolvimento do período.

Toda a tecnologia de saúde pública produzida e aplicada então tinha como ênfase aspectos ambientais biológicos com potencial epidêmico, além das soluções de regulação de atividades ligadas aos mercados, bens e serviços em uso. Nesse sentido, podemos falar que estas ações foram os rudimentos iniciais das Vigilâncias Epidemiológica e Sanitária.

Primeiro, portanto, uma agenda ambiental biológica que se manterá presente até a atualidade.

Sequencialmente, o que ocorreu? A chegada da industrialização trouxe novos riscos ambientais de natureza física, química e biológica também. Ar, água e solo passam a sofrer as consequências que descrevemos, os alimentos começam a ser produzidos com a aplicação de agrotóxicos em grande escala e a população já passa a ser exposta a tais "novidades".

Aplicando a mesma lógica, teríamos uma segunda fase de cunho físico-químico - ou biogeoquímico, para sermos mais precisos. No entanto, não era exatamente esse o cenário, pois a saúde pública brasileira não se manifestou em tempo quanto aos fenômenos típicos da industrialização. Por décadas vivemos o que poderíamos chamar de livre exposição ambiental à substâncias tóxicas em geral, por todas as vias e rotas possíveis. Ainda que fossem citados exemplos que mostrem casos excepcionais, a regra geral foi essa. Total descontrole ambiental, legislação ambiental parca e em paralelo, no cenário internacional, as primeiras iniciativas de um movimento ambiental em nascimento. 
Silêncio epidemiológico quanto ao impacto ambiental da industrialização por um lado e fortalecimento e desenvolvimento da agenda ambiental biológica por outro. A Vigilância Epidemiológica se fortaleceu e ampliou tecnologias de intervenção para doenças vetoriais e infecto contagiosas durante este período. Epistemologicamente, a teoria da história natural da doença foi largamente utilizada para fundamentar ações de saúde pública. Augusto (2003) reforça que a instituição do modelo de história natural da doença foi um avanço em relação ao modelo monocausal bacteriológico, porém ainda insuficiente para compreensão de toda complexidade envolvida no processo saúde-doença e suas inter-relações e interdependências.

Como apontamos, em um segundo momento, especificamente 0 de industrialização, tivemos um período de livre exposição à poluentes ambientais. Existiram legislações ambientais nesta fase, mas não uma política que atacasse o problema de maneira integrada, interligando ecossistemas e dispondo de uma organização administrativa e hierárquica. Diferentes leis eram fiscalizadas por diferentes atores.

Nesse momento, a governamentalidade se mantinha a mesma? Não exatamente. Desenvolvimento econômico sim, desenvolvimento social mínimo e controle ambiental mínimo - ou tendendo a zero, para honrar possíveis exceções. A industrialização deveria ocorrer a qualquer custo, a política imposta por capitais estrangeiros não se importava com o meio ambiente. Esse não tinha custo, a poluição seria uma externalidade inevitável e sem voz.

Aos poucos os fenômenos de transição demográfica e epidemiológica foram colocando em evidência doenças que não tinham conexão necessária com o paradigma infectocontagioso. Vermelho e Monteiro (2006) descrevem os fenômenos correlacionando o segundo momento ao primeiro. A transição demográfica foi descrita pela primeira vez em 1940 e estabeleceu em fases específicas as implicações em taxas de fecundidade, mortalidade e natalidade com influência no perfil populacional. Concomitantemente ocorreu a transição epidemiológica. No Brasil, esta é classificada dentro do modelo de transição epidemiológica retardado, ou seja, com declínio da mortalidade e fecundidade apenas no século XX, a partir de 1940 e 1960 
respectivamente. Na década de 60 é que se efetua mais diretamente o cruzamento das curvas de doenças infecciosas e parasitárias (descendente) com as curvas de doenças do aparelho circulatório em ascendência. Apenas na década de 80 as curvas de agravos relacionados à causas externas e as neoplasias cruzaram a curva das doenças infecciosas e parasitárias (VERMELHO \& MONTEIRO, 2006).

Tal descrição coincide, cronologicamente, com o que descrevemos quando abordamos o processo de surgimento da industrialização acompanhado da implantação das políticas de saúde pública no país. Mais interessante ainda para o caso do Brasil, à luz da nossa temática, é a descrição dos autores acerca do conceito de transição de risco:

...que se refere às mudanças dos padrões de determinação das doenças que
acompanham o desenvolvimento econômico. Ocorre uma mudança das
exposições ambientais tradicionais e seu risco associado, por aqueles da
modernização da agricultura e da industrialização. Muitos países em
desenvolvimento convivem, simultaneamente, com os antigos e modernos
riscos (exemplo, água contaminada, pesticidas, acidentes de trânsito com
veículos a motor e todo tipo de violência urbana) (VERMELHO E MONTEIRO,
2006 p.93).

A Política Nacional de Meio Ambiente brasileira é de 1981, somente quando passamos a falar oficialmente de impacto ambiental e, apenas a partir de então, considerar suas implicações na saúde humana. Não fossem os avanços da saúde ocupacional, que mais à frente virão a contribuir para a compreensão da exposição da população a contaminantes ambientais, a memória epidemiológica quanto ao reconhecimento de problemas dessa natureza seria insuficiente.

O que poderíamos chamar de terceira fase, porém, no campo da saúde pública, temporalmente é mais tardia: o Decreto que marca a criação da Vigilância Ambiental foi publicado no ano 2000! A exposição aos fatores físicos e químicos começou, para sermos razoáveis, na década de 40 do século XX. A área de Vigilância Ambiental surgirá apenas no ambiente técnico político do SUS. A existência e o fortalecimento das Vigilâncias Epidemiológica e Sanitária não incidiram sobre esse problema.

Haveria, então, um terceiro momento em andamento, que dá início, na política de saúde, a uma agenda em complemento à biológica: a da reação aos fatores físicos 
e químicos. Uma agenda biogeoquímica, se considerarmos a dinâmica entre os compartimentos ambientais discutidos à pouco.

Podemos propor então uma genealogia da Vigilância Ambiental no campo da saúde em três etapas, sistematicamente dispostas da seguinte maneira:

- Primeira etapa: agenda do saneamento - ou biológica;

- Segunda etapa: agenda da industrialização - ou livre exposição, sem ação de saúde quanto a exposição aos poluentes ambientais;

- Terceira etapa: agenda do despertar da política de saúde para o problema da poluição em sua vertente biogeoquímica - que instituiu a Vigilância Ambiental e segue vigente até nossos dias.

Reforçamos que a presente genealogia tem como foco a saúde pública. São os tempos históricos desse campo que estamos destacando, ainda que em outras esferas movimentos importantes também tenham ocorrido - como buscamos ilustrar brevemente até aqui. De todo modo, cumpre enfatizar que as etapas propostas abrangem intervalos muito distintos: a primeira com cerca de 40 anos (na primeira república); a segunda com cerca de 70 anos (1940 a 1999); e a terceira desde então até nossos dias, isso porque a Saúde só formaliza sua agenda biogeoquímica em 2000, com a criação da Vigilância Ambiental.

Julgamos ter demonstrado suficientemente a primeira etapa; quanto à segunda, que trabalhamos nos tópicos acerca do desenvolvimento da indústria e dos passivos ambientais correlatos, sua trama histórica contou com eventos, no Brasil e no mundo, que revelaram profundamente a displicência ecológica da mentalidade desenvolvimentista então em voga.

Estamos falando de grandes acidentes químicos no Brasil e no mundo que vitimaram de maneira impactante populações e ecossistemas. Faremos uma breve descrição deles para ilustração: 
- Em 01 de junho de 1974, em Flixborough, Inglaterra, um vazamento de ciclohexano na planta da Nypron LTDA resultou em uma explosão de grandes proporções, culminando na morte de 28 pessoas e deixando 36 feridos graves (CETESB, 2017);

- Em 10 de julho de 1976, na cidade de Seveso, na Itália, uma nuvem tóxica contendo triclorofenol, triclorofenato de sódio, etileno glicol, hidróxido de sódio e grande quantidade de dioxinas foi emitida após uma reação química inesperada na indústria química Icmesa. Efeitos: danos à vegetação, aos pássaros e aos animais domésticos dos arredores, bem como queimaduras, inflamações e lesões cáusticas em pelo menos 193 pessoa - entre estas, 170 menores de 15 anos (FREITAS, PORTE \& GOMEZ, 1995);

- Em 24 de fevereiro de 1984, na Vila Socó, município de Cubatão (SP), uma explosão em um oleoduto da Petrobrás culminou num incêndio com mais de 700.000 litros de gasolina, resultando em 508 óbitos imediatos (FREITAS, PORTE \& GOMEZ, 1995);

- Em 19 de novembro de 1984, em San Juan de Ixhuatepec, México, um vazamento de gás liquefeito de petróleo, em um tanque da Petróleos Mexicanos - Pemex, resultou em uma explosão de grandes proporções que causou pelo menos 550 óbitos registrados (FREITAS, PORTE \& GOMEZ, 1995);

- Em 02 de dezembro de 1984, em Bhopal, na Índia, um vazamento de 41 toneladas de metil-isocianato, um gás asfixiante, na empresa Union Carbide, resultou no óbito imediato de 2500 pessoas, conforme dados oficiais, sendo este considerado um dos mais graves acidentes químicos já registrados (FREITAS, PORTE \& GOMEZ, 1995);

- Em 26 de abril de 1986, em Chernobyl, antiga União Soviética, ocorreu um desastre sem precedentes: a explosão de um reator nuclear que culminou em milhares de vítimas, englobando danos que vão desde má-formação congênita 
até numerosos casos de câncer, apesar do balanço oficial da ONU, de 2005, falar em apenas 37 mortes oficiais (DUPUY, 2007);

A história recente da humanidade foi marcada por diversos outros - mas acreditamos que a repercussão mundial e local desta pequena seleção seja suficiente para demarcar o que denominamos como segunda etapa de nossa genealogia. Eventos de impacto midiático mundial que foram favorecendo a sensibilização quanto à questão saúde e meio ambiente.

Ainda no que tange à eventos importantes, algumas epidemias relacionadas à poluentes ambientais merecem destaque pelo seu caráter ilustrativo acerca da importância do tema e da necessidade de vigilância e acompanhamento da saúde das populações envolvidas:

- A biomagnificação de mercúrio, na baía de Minamata, Japão, a partir de 1932, que implicou na exposição da população consumidora do peixe da região. Os resultados, após 30 anos de exposição ao mercúrio, em sua forma metilada, foram mais de 2000 mortes e aproximadamente 8000 vítimas;

- Entre 1971 e 1972, no Iraque, ocorreu outra importante epidemia relacionada ao mercúrio em sua forma metilada, desta vez a partir do uso de um pesticida mercurial em trigo inadvertidamente utilizada para produção de alimentos. Aqui os resultados foram 460 óbitos e mais de 600 vítimas;

- Novamente no Japão, uma contaminação de óleo de arroz com bifenila policlorada (PCB), no período de 1968 a 1973, fez mais de 1.200 vítimas, com 22 óbitos, causando uma cadeia de efeitos que repercutiu, principalmente, em problemas oculares, cutâneos e no sistema nervoso;

- Nos Estados Unidos e na Austrália, uma contaminação por chumbo a partir de uma fábrica de tintas por um longo período, 1892 a 1971, fez inúmeras vítimas, principalmente entre crianças, com efeitos que vão desde déficit intelectual a anemia.

As epidemias descritas foram coletadas por Tambellini e Câmara (1998). 
No Brasil dispomos de muitos eventos da mesma natureza - entre eles o episódio envolvendo o Césio-137, em Goiânia (GO) (1987), é um dos mais famosos, gerando, além de vítimas fatais diretas, outras centenas de casos relacionados a exposição à radiação. A existência da Associação de Vítimas do Césio 137, organizada pelos próprios afetados, demonstra bem esse fato. Foram monitoradas 112.800 pessoas após o evento. Um único aparelho de radioterapia gerou $3.500 \mathrm{~m}^{3}$ de lixo radioativo ainda hoje depositados no município de Abadia (GO) (GOVERNO DE GOIÁS, 2017).

Ainda é fundamental destacar dois fatos, ocorridos no Brasil, paralelos ao conjunto de eventos acima relatados, que propiciaram uma melhor estruturação de ações em relação à saúde e meio ambiente. São eles a criação de dois importantes órgãos técnicos ambientais que contribuíram e contribuem para a produção de informação ambiental relativa aos diversos tipos de poluição: a CETESB (Companhia Ambiental do Estado de São Paulo), no Estado de São Paulo, e a FEEMA (Fundação Estadual de Engenharia do Meio Ambiente), no Estado do Rio de Janeiro, a primeira em 1968 e a segunda em 1975.

Ribeiro (2004) destaca que:

As preocupações com os problemas ambientais e sua vinculação com a saúde humana foram ampliadas no Brasil, inclusive, a partir da década de 1970. Durante essa década, foi criada a SEMA (Secretaria Especial de Meio Ambiente) e, a exemplo dos EUA, foram estabelecidos os Padrões de Qualidade do Ar e das Águas. No estado de São Paulo, foi criado um órgão de controle ambiental, visando controlar, num primeiro momento, a poluição de origem industrial e, da década de 1980 em diante, também a poluição causada por veículos. A despeito de ser uma política setorial, desvinculada do setor saúde, ela trouxe alguns resultados positivos, com reflexos nas condições de saúde (RIBEIRO, 2004 p.76)

Ainda durante a nossa denominada segunda etapa, identificamos uma sequência de eventos que podem ser considerados chaves para a criação da agenda ambiental no mundo - com incidência direta no Brasil. São eles: a Conferência de Estocolmo em 1972, na Suécia, gerando a Declaração de Estocolmo sobre o Meio Ambiente Humano; o chamado relatório Lalonde, de 1974 no Canadá, apontando o ambiente como relevante no processo saúde-doença; a Declaração de Alma-Ata para os Cuidados Primários em Saúde de 1978, fruto da I Conferência Internacional sobre 
Cuidados Primários em Saúde, na Rússia; a Carta de Otawa em 1986, também do Canadá, fortalecendo a importância da participação das comunidades; a Rio-92, no Rio de Janeiro em 1992, ou Conferência das Nações Unidas sobre o Meio Ambiente e Desenvolvimento, que originou a Agenda 21 e; em 1995, a Conferência PanAmericana sobre a Saúde e Ambiente no Desenvolvimento Humano Sustentável (COPASAD), que culminou no Brasil com a elaboração do "Plano Nacional de Saúde e Ambiente no Desenvolvimento Sustentável - Diretrizes para Implementação" (ROLFHS et al., 2011).

Somado a este conjunto de eventos, o Movimento da Reforma Sanitária Brasileira, ao culminar no Sistema Único de Saúde (SUS), via VIII Conferência Nacional de Saúde em 1986, e na Lei Orgânica no 8.080, de 1990, deu ao meio ambiente a condição de fator determinante e condicionante na saúde (ROLFHS et al., 2011).

A criação, em 1991, do Departamento de Informática do SUS (DATASUS) foi um evento mister para a viabilização do funcionamento modernizado das áreas de vigilância e outros setores. Sem informações, em nenhum momento haveria viabilidade de desenvolvimento de qualquer indício de Vigilância Ambiental. O site do órgão informa:

O Departamento de Informática do Sistema Único de Saúde (DATASUS)
surgiu em 1991 com a criação da Fundação Nacional de Saúde (FUNASA),
pelo Decreto 100 de 16.04 .1991 , publicado no D.O.U. de 17.04 .1991 e
retificado conforme publicado no D.O.U. de 19.04.1991. Na época, a
Fundação passou a exercer a função de controle e processamento das
contas referentes à saúde que antes era da Empresa de Tecnologia e
Informações da Previdência Social (DATAPREV). Foi então formalizada a
criação e as competências do DATASUS, que tem como responsabilidade
prover os órgãos do SUS de sistemas de informação e suporte de informática,
necessários ao processo de planejamento, operação e controle (DATASUS,
2017).

No Brasil, a partir das estratégias de ampliação do Movimento de Justiça Ambiental pelo mundo, ocorreu em 1991 o lançamento da Rede Brasileira de Justiça Ambiental, com a participação de universidades, organizações não governamentais, sindicatos e outros. Atualizando em nosso país o debate americano, a rede propôs como Justiça Ambiental princípios e práticas que: asseguram que nenhum grupo social suporte uma parcela desproporcional de consequências ambientais negativas; 
asseguram acesso justo e equitativo aos recursos ambientais do país; asseguram amplo acesso às informações relevantes de interesse ambiental; e favoreçam a constituição de sujeitos coletivos de direito. Etnias, classes sociais e minorias são os que mais arcam com os custos da poluição ambiental gerada pelo grande capital, de acordo com os teóricos desse campo (ACSELRAD et al, 2009).

Rigotto e Augusto (2007) destacam ainda que em especial pós anos 90:

\begin{abstract}
Vários outros movimentos sociais vêm assumindo a condição de sujeitos na defesa do ambiente, da saúde e da vida. São trabalhadores urbanos que lutam pelo banimento do amianto e de poluentes orgânicos persistentes, ou que criam novas formas de destinar os resíduos que produzimos; moradores de regiões metropolitanas que buscam garantir políticas adequadas de saneamento ambiental ou de moradia; comunidades ribeirinhas que defendem as terras das grandes barragens hidrelétricas; povos da Amazônia que também tentam proteger a floresta dos madeireiros, garimpeiros e especuladores. (RIGOTTO E AGUSTO, 2007 p. 482)
\end{abstract}

Além disso, uma agenda mundial de segurança química também teve papel de relevo na criação da área. Entre as medidas em questão, podemos apontar a Convenção de Roterdã, de 1998, que abordou o Procedimento de Consentimento Prévio Informado Aplicado a Certos Agrotóxicos e Substâncias Químicas Perigosas Objeto de Comércio Internacional, e a Convenção de Estocolmo, de 2001, quanto aos poluentes orgânicos persistentes, POPs, que vêm sendo atualizada periodicamente e obriga a utilização de tecnologias e medidas de proteção contra acidentes/derramamentos não intencionais (MINISTÉRIO DO MEIO AMBIENTE, 2017).

Pelo exposto até aqui, é possível destacar que durante a etapa de livre exposição houve importante movimentação nacional e internacional exigindo voz aos problemas ambientais em andamento.

No campo acadêmico, Tambellini e Câmara (1998) publicaram um artigo de referência para a fundamentação da relação saúde e meio ambiente e para a incorporação deste binômio aos domínios mais amplos da saúde coletiva - intitulado "A temática saúde e meio ambiente no processo de desenvolvimento do campo da saúde coletiva: aspectos históricos, conceituais e metodológicos". Logo no início do 
artigo é destacada a importância da epidemiologia enquanto ciência que viabiliza a produção de conhecimento de desfechos relacionados à saúde e situações/condições ambientais. Com o surgimento do campo da saúde coletiva, a disciplina Saúde Ambiental vai se estruturando com apoio de elementos da Geografia Crítica, de Milton Santos, e em consonância com o desenvolvimento da área de Saúde do Trabalhador, a partir da relação produção-ambiente-saúde e seus artigos, dissertações e teses.

Ao destacar a emergência da saúde ambiental a partir da maturação do campo da saúde coletiva, os autores elucidam a riqueza de tal conceituação:

\begin{abstract}
Neste espaço da Saúde Coletiva, o conceito fundamental pode ser e passa a ser visto concretamente, ou seja, é categorizado e analisado do ponto de vista científico como processo saúde-doença com seus determinantes e condicionantes históricos, genéticos e estruturais (biopsíquicos, sociais e ecológicos) que neste processo se manifestam. Assim, ao interagirem tais condicionantes (externos ao sujeito ou internalizados) com o seu próprio alvo (indivíduo/coletividade) e no interior de um processo complexo, ocorre sua particularização na dependência dos elementos em jogo e suas características específicas (capacidade de produzir dano/lesar, capacidade de se defender/responder), obedecendo a determinadas normas biológicas e sociais e produzindo o doente/a doença. Portanto, o processo-objeto de estudo considerado pela Saúde Coletiva é aquele que constitui a doença tal qual é encontrada nas coletividades sob estudo (TAMBELLINI \& CÂMARA, 1998 p.52).
\end{abstract}

Os mesmos autores, sob essa perspectiva, informam que:

Nas Américas, a Saúde Ambiental, antes relacionada quase que exclusivamente ao saneamento e qualidade da água, incorporou outras questões que envolvem poluição química, pobreza, equidade, condições psicossociais e a necessidade de um desenvolvimento sustentável que possa garantir uma expectativa de vida saudável para as gerações atuais e futuras (CÂMARA \& TAMBELLINI, 2003 p.96).

Na citação de 1998, acima, os autores consideraram indissociável a tríade produção-ambiente-saúde e apontaram como tal compreensão é fundamental para a produção de conhecimento qualificado tanto na saúde ambiental como na saúde do trabalhador, discutindo aspectos metodológicos de correlação entre as três.

Helena Ribeiro (2004) ilumina mais um aspecto relevante para a genealogia aqui proposta. Assim como apontado em Câmara e Tambellini (1998), ela destaca duas definições de Saúde Ambiental que ilustram bem o impacto dos diversos eventos 
e sua repercussão na Organização Mundial de Saúde (OMS). A primeira definição, mais antiga, aponta que: "Saúde Ambiental é o campo de atuação da saúde pública que se ocupa das formas de vida, das substâncias e das condições em torno do ser humano, que podem exercer alguma influência sobre a sua saúde e o seu bem-estar"; a segunda definição vem da Carta de Sofia, após um encontro da Organização Mundial de Saúde realizado nesta cidade, na Bulgária em 1993:

Saúde ambiental são todos aqueles aspectos da saúde humana, incluindo a qualidade de vida, que estão determinados por fatores físicos, químicos, biológicos, sociais e psicológicos no meio ambiente. Também se refere à teoria e prática de valorar, corrigir, controlar e evitar aqueles fatores do meio ambiente que, potencialmente, possam prejudicar a saúde de gerações atuais e futuras (OMS, 1993 in: RIBEIRO, 2004 p.72).

Em breve veremos o quanto essa definição se encaixa perfeitamente no desenho da Vigilância Ambiental instituído no Brasil.

É certo que esse conjunto de eventos formou um terreno favorável para a emergência da área da Vigilância Ambiental em nosso país. Retomamos aqui que a perspectiva genealógica que adotamos em Foucault não pretende que os relatos acima descritos sejam lidos como uma espécie de somatória que culmina na formação da Vigilância Ambiental. São as interações, as discussões e debates políticos e científicos, os movimentos governamentais e não governamentais, que criaram a possibilidade de emergência da área. No plano acadêmico, mencionamos há pouco como o surgimento da saúde coletiva enquanto disciplina foi importante. Nessa mesma área a noção de promoção da saúde também foi fundamental para garantir à temática ambiental um papel importante no processo saúde-doença.

Refletindo sobre a implantação da Vigilância Ambiental no país, Barcellos e Quitério (2006) sustentam que:

O modelo que permite visualizar o setor saúde nesse cenário é preconizado pela promoção da saúde, que estabelece como estratégias fundamentais à defesa da saúde, a capacitação e a mediação. Por defesa da saúde entendese a luta para que fatores políticos, econômicos, socioculturais e ambientais sejam cada vez mais favoráveis à saúde. A capacitação pressupõe indivíduos aptos a conhecer e controlar os fatores determinantes da sua saúde. Finalmente, o entendimento de que a saúde se realiza num contexto de múltiplos atores e interesses determina a necessidade de mediação entre eles. Nesse sentido, a saúde deve ser vista menos como um compartimento 
da administração pública e mais como um pressuposto na formulação de políticas, planos, programas e projetos. A participação da sociedade civil neste processo é primordial para garantir a priorização, continuidade e transparência de políticas públicas (BARCELLOS e QUITÉRIO, 2006 p.174).

Lia Giraldo da Silva Augusto (2003) destaca três dimensões fundamentais para a implantação de um sistema de Vigilância Ambiental: valorização do contexto, agregação da dimensão territorial e aplicação do princípio da precaução e a intersetorialidade (AUGUSTO, 2003).

O Princípio da Precaução é outro conceito que deve servir de guia para a ação em vigilância ambiental, isto é, não se deve priorizar a ação apenas pela ocorrência de doenças e desastres ou acidentes, mas antecipar esses eventos pelo reconhecimento, anterior, dos riscos e dos contextos nocivos à saúde (AUGUSTO, 2003 p.183).

Tecnicamente, o desenvolvimento de modelos de exposição para vigilância de populações e riscos ambientais foi mais um fator que fundamentou a criação da área.

O mais citado foi proposto pela Organização Mundial de Saúde. O modelo é composto pelos seguintes marcos: força motriz, pressão, situação, exposição, efeito e ação. Por força motriz entende-se questões que influenciam a saúde de um nível mais macro como desenvolvimento econômico, aumento da população, pobreza, entre outros; por pressão podemos citar aspectos como produção, consumo, disposição de resíduos ambientais; por situação entende-se a própria contaminação ambiental, por exemplo; por exposição tomamos os diversos contextos onde a população está diretamente em rota de exposição aos contaminantes ambientais; e por efeitos, finalmente, temos as consequências diretas da cadeia de desenvolvimento propriamente dita, ou seja, doenças, mortes e intoxicações, entre outros. O item ação corresponde ao momento onde algum tipo de intervenção pode ser estabelecido em alguns dos níveis para mitigação das consequências da cadeia (MACIEL FILHO et al, 1999).

Em termos de análise risco, o modelo de Tracker et al (1996) relacionando fontes de risco, exposição e agravos à saúde foi anterior ao que descrevemos acima, também descritos por Barcellos e Quitério (2006) como modelo FPEEEA (força motriz 
- pressão - estado - exposição - efeito - ação) e originalmente elaborados por Corvalán et al (1997).

O essencial destas proposições é a adaptação conceitual ao corroborado pelos movimentos intelectuais que geraram os campos da saúde coletiva e da promoção da saúde tal como observamos, afastando a inocente dicotomização risco-exposição e favorecendo uma leitura complexa que precisa, em última análise, ser composta por mais de um indicador. A Vigilância Ambiental em Saúde deve operar com o desenvolvimento e aperfeiçoamento de indicadores de saúde específicos para a relação saúde e meio ambiente com foco na exposição a partir de uma perspectiva que garanta a visão da relação complexa entre meio ambiente e sociedade (BARCELLOS e QUITÉRIO, 2006).

Todo o exposto acima visou elucidar melhor aspectos que consideramos fundamentais para a genealogia e que ocorreram durante o período que denominamos como segunda fase. A partir daqui descreveremos como essa área foi se estruturando na terceira fase por nós proposta. Uma construção tardia, mas também por isso, imprescindível.

Se antes através da Vigilância Epidemiológica e ainda antes, no início da Saúde Pública, já conhecíamos o controle de vetores, só no ano 2000 a Vigilância Ambiental foi formalmente estruturada. Inicialmente a área foi denominada Vigilância Ambiental em Saúde. Em uma série de documentos legais, descritos na tese de doutorado de Villardi (2015), vemos a função administrativa ser criada por meio do Decreto 3.450, de 09 de maio de 2000, e a primeira formatação de coordenação ocorrer na Portaria Funasa 420, de 10 de agosto de 2000. Essa última criou a Coordenação Geral de Vigilância Ambiental - CGVAM - que foi inicialmente dividida em fatores de risco biológicos e não biológicos, divisão que não perdurou.

A Vigilância Ambiental terminou focada em fatores físicos, químicos e geológicos, deixando o biológico de lado. Trata-se de um curioso movimento que excluiu, justamente da área que se autodenomina ambiental, um fator ambiental tão 
importante, concreto e, mais, fundador de importantes movimentos de saúde pública no país.

O manual da Fundação Nacional de Saúde (FUNASA, 2002a) é explícito ao reconhecer o que detalhamos mais ao início da tese:

\begin{abstract}
Um importante precursor da Vigilância Ambiental em Saúde desenvolveu-se vinculado às ações de controle de fatores ambientais biológicos como vetores, animais transmissores da raiva, acidentes com animais peçonhentos, contaminação biológica da água de consumo humano (cólera, diarreias, etc.) e, mais recentemente, fatores físicos e químicos relacionados à contaminação ambiental (FUNASA, 2002a p.12).
\end{abstract}

Essa separação não havia sido planejada no princípio. A evidência consta no próprio material que propõe a estruturação do Sistema Nacional de Vigilância Ambiental em Saúde (SINVAS) ao dividir a Coordenação Geral de Vigilância Ambiental em Saúde, em respeito a Portaria FUNASA nำ 410, de 10 de agosto de 2000, em duas coordenações principais conforme artigos 93ำ e 94을

Art. $93^{\circ}$. À Coordenação de Vigilância de Fatores de Riscos Biológicos - COFAB, compete:

I. Coordenar, normatizar e supervisionar as ações relativas ao controle de vetores, hospedeiros e reservatórios de doenças transmissíveis e animais peçonhentos;

II. Coordenar e normatizar os sistemas de informações relativos ao controle de vetores, hospedeiros e reservatórios de doenças transmissíveis e animais peçonhentos;

III. Consolidar e analisar as informações produzidas e elaborar indicadores para o monitoramento do controle de vetores, hospedeiros e reservatórios de doenças transmissíveis e animais peçonhentos; e

IV. Coordenar as ações relativas ao sistema de monitoramento da resistência dos vetores aos inseticidas.

Art. 94․ À Coordenação de Vigilância de Fatores de Riscos Não-Biológicos (CONAB) compete:

I. Coordenar, normatizar e supervisionar as atividades relativas à vigilância dos contaminantes ambientais na água, no ar e no solo de importância e repercussão na saúde pública, bem assim dos riscos decorrentes dos desastres naturais e acidentes com produtos perigosos;

II. Estabelecer e monitorizar padrões máximos de exposição a fatores não biológicos, que ocasionem riscos à saúde da população; 
III. Coordenar e normatizar o sistema de informações relativo à vigilância e ao controle de contaminantes ambientais na água, no ar e no solo de importância e repercussão na saúde pública, bem assim aos riscos decorrentes dos desastres naturais e acidentes com produtos perigosos; e

IV. Consolidar e analisar as informações produzidas e elaborar indicadores para subsidiar as ações e o monitoramento para o controle de contaminantes ambientais na água, no ar e no solo, de importância e repercussão na saúde pública e aos riscos decorrentes dos desastres naturais e acidentes com produtos perigosos.

Porém, em 2005, a Instrução Normativa n 1, de 07 de março de 2005, instituiu uma sutil mudança de nome com significativa mudança de atuação, basicamente dividindo ao meio a antiga CGVAM e renomeando a área, que mudou de Vigilância Ambiental em Saúde para Vigilância em Saúde Ambiental. Trata-se da instituição do Subsistema Nacional de Vigilância em Saúde Ambiental, o SINVSA, que conforme esclarece a própria norma:

Art. 1ํ - O Subsistema Nacional de Vigilância em Saúde Ambiental - SINVSA compreende o conjunto de ações e serviços prestados por órgãos e entidades públicas e privadas, relativos à vigilância em saúde ambiental, visando o conhecimento e a detecção ou prevenção de qualquer mudança nos fatores determinantes e condicionantes do meio ambiente que interferem na saúde humana, com a finalidade de recomendar e adotar medidas de promoção da saúde ambiental, prevenção e controle dos fatores de riscos relacionados às doenças e outros agravos à saúde, em especial:

I. Água para consumo humano;

II. $a r$;

III. solo;

IV. contaminantes ambientais e substâncias químicas;

V. desastres naturais;

VI. acidentes com produtos perigosos;

VII. fatores físicos; e

VIII. ambiente de trabalho.

Uma explicação para essa ruptura pode ser dada a partir da nada sutil diferença entre os conceitos de Vigilância em Saúde e Vigilância da Saúde, uma vez que o Ministério da Saúde opta pela noção de Vigilância em Saúde. 
Um tradicional material de referência de 2002, denominado "Textos de Epidemiologia para Vigilância Ambiental em Saúde", contextualiza essa área dentro da Vigilância da Saúde com todas as implicações da integração diante da perspectiva da Saúde Coletiva e da Promoção da Saúde, com forte ênfase em Epidemiologia Ambiental. Se compararmos com o mais recente manual da Vigilância em Saúde Guia de Vigilância em Saúde de 2014 - notaremos que não há menção à Vigilância em Saúde Ambiental e nem à Vigilância Sanitária, componentes estabelecidos da Vigilância em Saúde, desde a Portaria 1378/2013, a mais recente anterior ao Guia. O que ocorre, de mais aproximado, é a menção do tópico intoxicação exógena, assim definido: "intoxicação exógena é o conjunto de efeitos nocivos representados por manifestações clínicas ou laboratoriais que revelam o desequilíbrio orgânico produzido pela interação de um ou mais agentes tóxicos com o sistema biológico" (MINISTÉRIO DA SAÚDE, 2014).

Aqui é importante destacar a crítica de Barcellos e Quitério (2006) sobre a implantação efetiva da Vigilância Ambiental no Brasil, a partir do preconizado pelo próprio SUS:

Segundo a lógica de descentralização, a execução dos programas é de co-
responsabilidade do município ou, dentro desses o distrito sanitário, o que
impõe a necessidade de se estabelecer canais de diálogo entre as diferentes
esferas de governo. O Sistema Nacional de Vigilância Ambiental em Saúde
(SINVAS) foi regulamentado com a Instrução Normativa No 1 do Ministério da
Saúde, de 25 de setembro de 2001 , que definiu competências no âmbito
federal, dos Estados e dos municípios. No entanto esse sistema vem
adquirindo diferentes configurações institucionais em cada um desses níveis
de governo. Nas secretarias estaduais e municipais de saúde, a vigilância
ambiental em saúde tem sido organizada, ora dentro dos departamentos de
epidemiologia, ora em departamentos de vigilância sanitária, ora como
departamentos autônomos. Na rede básica de saúde, a atuação de agentes
de saúde dos Programas de Saúde da Família e de controle de endemias
podem garantir a necessária capilaridade do sistema (BARCELLOS e
QUITÉRIO, 2006 p.175).

Reforçando ainda que:

Um outro limitante diz respeito à própria cultura do setor saúde, voltado historicamente para a vigilância de agravos. Apesar dos incentivos estabelecidos por meio de projetos induzidos (e.g., Vigisus), de instrumentos financeiros (e.g., Programação Pactuada Integrada) e de programas (e.g., PACS/PSF) que promovem a superação do modelo assistencial do SUS, alguns problemas têm sido enfrentados para a efetiva implementação das ações de vigilância ambiental como prática do setor saúde. A vigilância em saúde é constituída pelas etapas de coleta, análise e interpretação sistemática de dados sobre eventos de saúde que afetam a população. A 
vigilância da saúde tem uma concepção mais abrangente, além da simples análise de situação ou da integração institucional entre a vigilância sanitária e epidemiológica. Ela prevê a intervenção sobre problemas de saúde; a ênfase em problemas que requerem atenção e acompanhamento contínuos; a operacionalização do conceito de risco; a articulação de ações de promoção, prevenção e assistência; a atuação intersetorial; as ações sobre o território; e a intervenção sob a forma de operações. A ampliação do campo de atuação da vigilância da saúde faz parte do mesmo processo de descentralização e territorialização dessas ações (BARCELLOS e QUITÉRIO, 2006 p.175).

Dessa forma, fica claro que dizer Vigilância Ambiental em Saúde e, por outro lado, Vigilância em Saúde Ambiental comporta uma importante diferença, cabendo considerar sinônimos apenas Vigilância Ambiental e Vigilância em Saúde Ambiental.

Um documento de 2009 intitulado "Subsídios para construção da política nacional de saúde ambiental" contém uma breve nota de rodapé que diz: "no âmbito do SUS, a vigilância em saúde ambiental relacionada aos fatores biológicos é exercida pelos respectivos controles de doenças transmissíveis." Este mesmo documento enfatiza a necessidade de integração intra e intersetorial de diversos órgão governamentais para efetiva proteção à saúde das populações no que diz respeito aos fatores de risco ambientais em geral, e destaca o papel da articulação da área da promoção da saúde (BRASIL, MINISTÉRIO DA SAÚDE, 2009).

As alterações organizacionais não pararam aí. Em 2009 foi criado o Departamento de Vigilância em Saúde Ambiental e Saúde do Trabalhador - DSAST, por meio do Decreto no 6.860/2009, integrado pela Coordenação Geral de Vigilância em Saúde Ambiental - CGVAM e pela Coordenação Geral de Saúde do Trabalhador - CGST, de forma a alcançar maior integração das ações de vigilância em saúde ambiental e da saúde do trabalhador no âmbito dos territórios. O SINVSA permaneceu o mesmo.

O resultado atual foi a estruturação de três grandes programas/sistemas de informação nacionais, seguindo em princípio a lógica dos compartimentos ambientais e outro dando destaque ao problema dos desastres ampliados. São eles:

- O Programa Nacional de Vigilância da Qualidade da Água para o Consumo Humano - VIGIÁGUA, programa que fiscaliza a qualidade da água distribuída 
por Estados através das diversas concessionárias, além de regular nos mesmos termos a água de poços profundos e rasos quanto a parâmetros químicos e biológicos básicos até a presença de substâncias mais complexas oriundas de atividades antrópicas;

- O Programa de Vigilância de Populações Expostas a Contaminantes Químicos - VIGIPEQ, dentro do qual opera a Vigilância de Populações Expostas a Solos Contaminados - VIGISOLO, para as situações de áreas contaminadas; o VIGIQUIM, havendo aqui a priorização em nível nacional das substâncias amianto, mercúrio, benzeno, chumbo e agrotóxicos, bem como o Programa de Vigilância de Populações Expostas à Poluição Atmosférica - VIGIAR, programa que pretende monitorar os episódios de picos de poluição e seus efeitos em uma determinada população a partir de técnicas de associação/correlação epidemiológicas;

- E o Programa de Vigilância em Saúde Ambiental dos Riscos decorrentes de Desastres - VIGIDESASTRE, que presta apoio a situações de desastres naturais ou antrópicos em todo o território nacional como por exemplo grandes enchentes e deslizamentos.

Tal formatação opera desde 2009, de acordo Villardi (2015), e segue estruturada como um dos componentes da Vigilância em Saúde pela Portaria 1378, de 9 de julho de 2013, e a atual Política Nacional de Vigilância em Saúde de 2018.

Há ainda mais um programa em destaque que pode ser encontrado na atual estrutura da CGVAM, trata-se do VIGIFIS - que faz a vigilância de populações expostas a radiações ionizantes e não ionizantes, que surgiu a partir da demanda da população de profissionais de saúde de regiões com alta concentração de minérios radioativos. O programa vem operando desde 2015 (SECRETARIA DE VIGILÂNCIA EM SAÚDE, VIGIFIS, 2017).

Em termos atuais, Rolfhs e seus colaboradores (2011) sustentam que: 
conhecimento e a detecção de mudanças nos fatores determinantes e condicionantes do meio ambiente que interferem na saúde humana, com a finalidade de identificar as medidas de prevenção e controle dos fatores de riscos ambientais relacionados às doenças ou outros agravos à saúde (ROLFHS et al, 2011 p.394).

Como é possível observar, a área da Vigilância Ambiental se estrutura totalmente após a mais dura industrialização e mesmo após o ápice do paradigma ambiental. Ela é consequente.

De toda forma, podemos destacar um conjunto de eventos nacionais que fortaleceram a área:

- A I Conferência Nacional de Saúde Ambiental, realizada em Brasília em 2009, evento que uniu pela primeira vez os Ministérios da Saúde, das Cidades e do Meio Ambiente em volta da temática, visando a - ainda não corroborada Política Nacional de Saúde Ambiental;

- Em Belém do Pará a Associação Brasileira de Saúde Coletiva (ABRASCO) realizou o I Simpósio Brasileiro de Saúde Ambiental, em 2010, com mais de 1.000 participantes e 600 trabalhos inscritos;

- Em 2014 ocorreu o II Simpósio Brasileiro de Saúde \& Ambiente, em Belo Horizonte, Minas Gerais.

Para além destes eventos mais direcionados, 'saúde ambiental' ou 'saúde e meio ambiente' foram e são temas recorrentes em eventos diversos da Saúde Coletiva, como por exemplo o Congresso Brasileiro de Epidemiologia e o de Saúde Coletiva, entre outros de abrangências nacionais, estaduais e internacionais.

Um evento particularmente especial foi $\circ \mathrm{V}$ Congresso Brasileiro de Epidemiologia, em 2002, onde a Associação Brasileira de Saúde Coletiva (ABRASCO) cria o grupo temático 'Saúde e Ambiente' com foco em desenvolvimento/sustentabilidade e ações em saúde e meio ambiente, permitindo com isso uma ação política mais contundente para a área, culminando inclusive nos dois simpósios citados acima (RIBEIRO, 2004). 
Outro ponto importante a ser destacado foi a estruturação da área de Vigilância Ambiental em conjunto com a de Vigilância em Saúde do Trabalhador, como já previam Tambellini e Câmara (1998). Tal perspectiva se fez evidente ao se considerar a inseparabilidade da relação produção e poluição e consequentemente da relação trabalhador e população do entorno de um estabelecimento poluidor. A Política Nacional de Saúde do Trabalhador e da Trabalhadora (Portaria 1823, de 23 de agosto de 2012), por sua vez, reza no artigo 8º, parágrafo II, alínea b quanto ao:

Fortalecimento e articulação das ações de Vigilância em Saúde, identificando
os fatores de risco ambiental, com intervenções tanto nos ambientes e
processos de trabalho, como no entorno, tendo em vista a qualidade de vida
dos trabalhadores e da população circunvizinha (BRASIL, 2012).

Reforçamos aqui que a tessitura dos programas estruturados pelo Ministério da Saúde nas últimas duas décadas é produto do clima político estabelecido tanto pelos acontecimentos ambientais que destacamos ao longo do texto quanto das conferências e dos documentos de orientação técnica, frutos dos mesmos, que foram se sucedendo com o passar dos anos.

O desenho da CGVAM hoje disponível no sítio do Ministério da Saúde é, portanto, o seguinte: 


\section{Figura 2 - Organograma da Coordenação Geral de Vigilância em Saúde Ambiental}

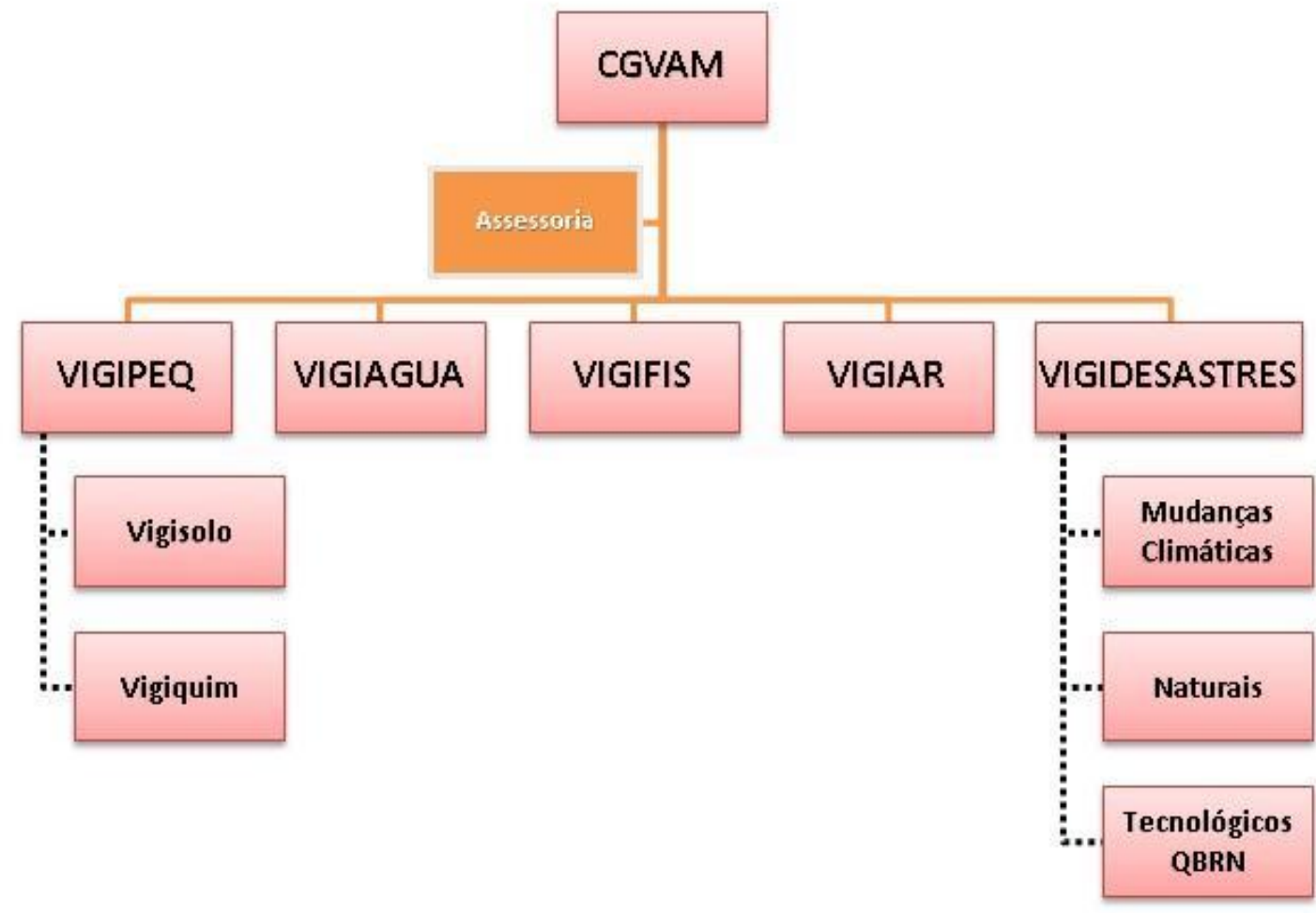

Fonte: Ministério da Saúde/Portal da Saúde, disponível em: http://portalsaude.saude.gov.br/index.php/oministerio/principal/leia-mais-o-ministerio/1173-secretaria-svs/vigilancia-de-a-a-z/vigilancia-ambiental//2-vigilanciaambiental/19352-vigilancia-ambiental-em-saude, acessado em 12.10.2017

Ao expor este desenho estabelecido no Ministério da Saúde, se faz necessário ressaltar que esta formatação passa longe de uniformidade nos demais entes federativos. Em diversas localidades a Vigilância Ambiental atua em par ora com a Saúde do Trabalhador, ora com a Vigilância Sanitária ou com a Vigilância Epidemiológica. A título de exemplo, entre diversos possíveis, na Secretaria de Estado da Saúde do Estado de São Paulo o Centro de Vigilância Sanitária possui uma área denominada Divisão de Ações sobre o Meio Ambiente (CVS, 2018)) e o Centro de Vigilância Epidemiológica uma área denominada Divisão de Doenças Ocasionadas pelo Meio Ambiente (CVE, 2018). Duas áreas ambientais na mesma Secretaria/Coordenação e em diferentes Vigilâncias.

Cabe perguntar para onde foram os fatores de risco biológicos. No momento a configuração destas questões ambientais se dá fora da Vigilância Ambiental, uma vez 
que dispomos dos seguintes setores na atual Secretaria de Vigilância em Saúde (SVS):

- Coordenação Geral dos Programas Nacionais de Controle e Prevenção da Malária e das Doenças Transmitidas pelo Aedes - CGPNCMD;

- Coordenação Geral de Doenças Transmissíveis - CGDT;

- Unidade Técnica de Vigilância de Zoonoses - UVZ/CGDT;

- Unidade Técnica de Vigilância das Doenças de Transmissão Vetorial - UVTV/CGDT/;

- Unidade Técnica de Doenças de veiculação Hídrica e Alimentar - UHA/CGDT.

Em suma, os fatores de risco ambientais de cunho biológico foram alocados na Coordenação Geral de Doenças Transmissíveis. Dessa forma, apesar da definição se referir a fatores de riscos ambientais, como já vimos, a Vigilância Ambiental ou Vigilância em Saúde Ambiental abrange apenas os fatores ambientais não biológicos e está inserida dentro do desenho conceitual da Vigilância em Saúde.

No artigo de ROLFHS et al (2011), que conta com diversos autores que contribuíram para a construção da Vigilância em Saúde Ambiental no Brasil, atentemos para a expressão "Vigilância em Saúde Ambiental" - não há referência à antiga Vigilância Ambiental em Saúde e seus conceitos integradores com a noção de Vigilância da Saúde, fazendo ainda referência em tom de novidade à Portaria 3.252/2009:

A integração das vigilâncias ganhou respaldo com a publicação da Portaria
do Ministério da Saúde no 3252 , de 22 de dezembro de 2009 , que veio ratificar
a necessidade de atuação conjunta das vigilâncias: epidemiológica, sanitária,
da situação de saúde, da saúde ambiental, da saúde do trabalhador, e da
promoção da saúde, com o objetivo de controlar determinantes, riscos e
danos à saúde de populações que vivem em determinados territórios,
garantindo a integralidade da atenção, o que inclui tanto a abordagem
individual como coletiva dos problemas de saúde (ROLFHS et al, 2011
p.394).

Não é difícil notar que a terceira fase da genealogia da Vigilância Ambiental evidencia um momento confuso, marcado pela transição das ideias da Vigilância da Saúde para as da Vigilância em Saúde. Com isso, observamos avanços e regressos no que tange à consolidação de uma área que veio oscilando na mão de diferentes 
gestores públicos, mas que se impõe como campo obrigatório de atuação integrada das diversas Vigilâncias. De todo modo, uma área mais integrativa e completa como proposta no início, com possibilidades de articulação mais ampliadas entre todos os fatores ambientais perdeu para o modelo tradicional separado. A visão biomédica estabelecida no desenvolvimento da saúde pública brasileira foi reafirmada nessa desintegração entre o biológico e o biogeoquímico na área da saúde.

Sem as estruturas que foram se estabelecendo durante as etapas que destacamos não haveria a possibilidade de emergência de uma área como a Vigilância Ambiental - e é nisso que enxergamos uma genealogia em consonância com a definição de Michel Foucault. Acompanhamos muitos vetores em ação, muito além da teorização, que não deixaram de acontecer. Sistematicamente a Vigilância Ambiental foi fruto da interação de acontecimentos imprescindíveis, tais como vimos:

- A consolidação de uma agenda ambiental de cunho biológico, em princípio, que legitimou as ações de saúde no meio ambiente;

- O desenvolvimento da industrialização com impactos ambientais expressivos, sem grandes intervenções governamentais durante décadas;

- O desenvolvimento e fortalecimento dos movimentos ambientais em todo o mundo;

- Os acordos e eventos internacionais que foram dando visibilidade ao tema;

- Os acidentes ambientais ampliados com consequências graves para populações humanas, que tiveram forte repercussão na mídia e na produção acadêmica;

- A criação dos órgãos ambientais no Brasil, bem como o aperfeiçoamento da legislação ambiental; 
- O desenvolvimento da Saúde Ambiental enquanto disciplina acadêmica e debate político;

- A produção acadêmica realizada à luz da Saúde Ambiental;

- A ambiente político-ideológico do surgimento e desenvolvimento da saúde como direito;

- Os diversos movimentos sociais que demandaram e sustentaram a necessidade de atenção aos efeitos da meio ambiente sobre a saúde humana e ecológica em geral;

- O aperfeiçoamento dos sistemas de informação em saúde;

- A concepção de Vigilância da Saúde como estratégia de proteção e integralidade do cuidado.

É a partir de toda essa atividade que a Vigilância Ambiental aparece como área de atuação necessária, passando a ser implantada como serviço de saúde nos moldes que descrevemos - ainda que mutilada em uma de suas asas fundantes: os fatores biológicos.

Na atual Política Nacional de Vigilância em Saúde, citada no início da exposição da tese, a definição de Vigilância em Saúde Ambiental aparece com três palavras à mais do que na conceituação de Rolfhs (2011), quais sejam: o aparecimento da palavra "serviços" ao lado de "ações" e a expressão "recomendar e adotar medidas" no lugar de apenas "identificar medidas" - figurando assim (com grifos nossos) no inciso $\mathrm{X}$ do artigo 6을

Vigilância em Saúde Ambiental: conjunto de ações e serviços que propiciam o conhecimento e a detecção de mudanças nos fatores determinantes e condicionantes do meio ambiente que interferem na saúde humana, com a finalidade de recomendar e adotar medidas de promoção à saúde, prevenção e monitoramento dos fatores de riscos relacionados às doenças ou agravos à saúde (PNVS, 2018). 
Tais palavras, longe de uma simples sutileza, apontam para a necessidade de estruturação e fortalecimento da Vigilância Ambiental no Brasil, uma vez que sua ontologia pede uma capacidade de ação maior nas esferas técnicas e jurídicas. 


\section{Capítulo 6 \\ Leitura biopolítica do contexto da Vigilância Ambiental}

No que tange à Vigilância Ambiental em sentido lato, vamos agora nos dedicar a uma interpretação biopolítica da questão. Se biopolítica pode ser compreendida como forma de governo de populações considerando em especial a saúde destas, como a Vigilância em Saúde Ambiental pode ser lida?

Vamos retomar o que de fato foi feito e as intenções ainda em aberto. Vimos que ações de cunho biológico são bem tradicionais na área e que refletiram, de certa forma, as primeiras intervenções de caráter biopolítico no país. Temos nessa área uma espécie de expertise por tradição. Ainda hoje, o problema dos vetores é gravíssimo no país e vivemos as mesmas questões da primeira república acrescidas de maiores potenciais de transmissão de doenças. Ainda mais recente que a epidemia de Zika Vírus, de 2016, no início de 2018 a Febre Amarela causou intensas buscas pela vacina a partir de casos de natureza silvestre na região sudeste do país (Ministério da Saúde, 2018).

Em matéria de exposição à tóxicos químicos, após décadas de descontrole podemos identificar alguns avanços, em especial no âmbito dos agrotóxicos, na vigilância da exposição de trabalhadores e populações e na avaliação de risco à saúde humana. Ainda assim, carecemos de informações ecotoxicológicas para que cenários sejam descobertos e avaliados. O problema de contaminantes emergentes vem desnudando essa problemática ao apontar fármacos, pesticidas, produtos de higiene pessoal, cafeína, hormônios, entre outros, em diferentes matrizes aquáticas. Tal fenômeno vem sendo chamado de efeito iceberg, em analogia às quantidades, concentrações e efeitos sinérgicos ainda desconhecidos (MONTAGNER, VIDAL \& ACAYABA, 2017).

Houve ainda avanços no problema da exposição de populações à áreas contaminadas. Apenas no Estado de São Paulo existem milhares de diagnósticos ambientais, estudos e remediações em andamento, proporcionando dados importantes para avaliações de risco à saúde humana - dando espaço para um olhar 
ao crônico e não necessariamente apenas ao agudo (CETESB, 2018). Em tese, exposições agudas são fáceis de notar em comparação à exposição crônica, que é lenta e gradual, com sinais muitas vezes de nível subclínico, conforme, por exemplo, os casos de exposição sistemática a pesticidas e os efeitos ototóxicos já bem documentados (KÓS et al, 2013).

Quanto à água e ao ar, os conhecimentos e evidências disponíveis foram largamente ampliados e a saúde ambiental, enquanto disciplina, segue se expandindo e produzindo conhecimento. Além disso, o tema alcançou relevante destaque em diversos âmbitos políticos, acadêmicos e midiáticos. A oitava edição do Fórum Mundial da Água, em 2018, é uma das evidências disso (World Water Forum, 2018).

Um desafio ainda permanece e diz respeito justamente ao preparo dos profissionais de saúde para este olhar. Quando o quadro de gênese ambiental não é agudo, a sensibilidade e o preparo para uma perspectiva de exposição crônica é bem mais difícil e torna "agudo" o desafio de preparar profissionais. Em geral, riscos ambientais físicos, químicos e, em muitos casos, biológicos atuam em nível molecular, havendo uma toxicologia por trás de seu mecanismo de ação que não é visível. Tudo se passa no campo da exposição e não necessariamente, portanto, no campo do efeito (QUANDT et al, 2014).

Com olhos apenas para os efeitos, a Vigilância em Saúde Ambiental pode atuar por meio de uma biopolítica que oculta verdades: havendo problemas para qualificar as situações de exposição, ela deixa de atuar (por ausência de diagnóstico) e indiretamente promove a ideia de que certos riscos e exposições não ocorrem. Tudo se dá como se o texto que define o papel da área ocorresse de fato, causando a ilusão, não necessariamente intencional, de que "os fatores determinantes e condicionantes do meio ambiente" estão sendo vigiados e monitorados. Em suma, a questão da efetividade da ação, da relevância dada na prática pelos gestores e profissionais, é determinante para uma vigilância verdadeira. 
É fato que temos um choque de governamentalidades: a governamentalidade expressa na política de saúde e a da agenda neoliberal em franco avanço no país e no mundo (GOUVEIA \& PALMA, 1999).

Estas agendas olham para tempos não necessariamente coincidentes: os tempos da natureza, que envolvem os mecanismos de transportes de poluentes e sua interação com os organismos, por exemplo, os tempos políticos, que remetem à efetividade de políticas de proteção à saúde em andamento, e finalmente o tempo econômico, que dá combustível para o andamento dos demais. Aparentemente a agenda de Saúde Ambiental e a agenda econômica neoliberal não combinam, estão em franca oposição: uma prima pela vida, a outra pela morte via parasitose da natureza e do ser humano.

Considerando o quadro de exposições ambientais a serem desvelados, podemos afirmar que em paralelo ao "fazer viver" há o "deixar-morrer" na forma de silêncio epistêmico e epidemiológico. Uma vigilância prejudicada por falta de recursos e/ou prioridade política corre o risco de chancelar um sistema de desenvolvimento mortífero justamente pela falta de investimento (a vigilância ambiental, no nosso caso).

Afinal, no contemporâneo o biopoder atua de modo sutilíssimo. Neves e Massaro (2009) nos ajudam a atualizar como o capital produz subjetividades. O biopoder atua dentro da sociedade através de mecanismos horizontais esparramados, de maneira:

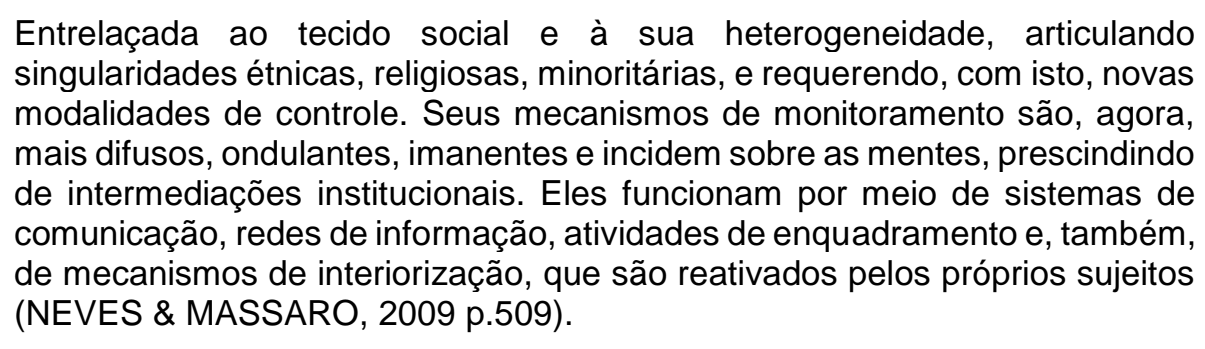

$\mathrm{Na}$ expressão dos mesmos autores: o que o capital faz funcionar é uma máquina axiomática.

Dessa forma: 
A saúde deixou de ser a "vida no silêncio dos órgãos", usando a expressão feliz de Leriche. Ela exige autoconsciência de ser saudável, deve ser exibida, afirmada continuamente e de forma ostentosa, constituindo um princípio fundamental de identidade subjetiva. A Saúde perfeita tornou-se a nova utopia apolítica de nossas sociedades. Ela é tanto meio quanto finalidade de nossas ações. Saúde para a vida. Mas também viver para estar em boa saúde. Viver para fazer viver as biotecnologias (ORTEGA, 2004 p.14).

Nas palavras de Furtado e Szapiro (2012):

À formulação segundo a qual o discurso da Promoção da Saúde é parte de um projeto biopolítico de controle social dos corpos, corresponde afirmarmos que a biopolítica opera hoje no registro do controle dos corpos e mentes. $E$ de que forma atua o dispositivo biopolítico de controle senão mediante a transformação do sujeito em autogestor dos seus riscos e das escolhas que faz, dos hábitos de vida? (Furtado \& Szapiro, 2012 p.819).

Essa sutileza denota a governamentalidade atual. Conforme Miller e Rose (2012):

\begin{abstract}
O poder político é exercido hoje através de uma profusão de alianças móveis entre diversas autoridades em projetos para governar uma multidão de aspectos da atividade econômica da vida social e da conduta individual. O poder não é tanto uma questão de impor restrições aos cidadãos quanto de "inventar" cidadãos capazes de suportar um tipo de liberdade controlada. A autonomia pessoal não é a antítese do poder político, mas um termo-chave em seu exercício, com muito mais razão porque a maioria dos indivíduos não é meramente súdita do poder, mas desempenha uma função em suas operações (MILLER \& ROSE, 2012 p.71).
\end{abstract}

Assim, com tanta ênfase no aspecto individual da saúde os riscos ambientais e seu desvelamento ficam prejudicados - e velados.

A Vigilância Ambiental depende, na maioria das vezes e nos casos mais críticos, de diagnósticos produzidos pelo regulado e não dispõe de capacidade técnico-operacional de confrontar os mesmos. De maneira geral, o que pode garantir uma boa atuação da vigilância ambiental é a atuação do técnico, da autoridade sanitária, ao avaliar, perguntar e interpretar as informações disponibilizadas. Salvo isso, o que alertamos aqui é relativo à perigosa conjunção da responsabilização da saúde a pesar sobre a população, como citado acima, e a possibilidade de uma ação de vigilância mascarada, imbuída de poder e destituída de recursos que promoveriam uma autêntica identificação de riscos e garantiriam uma atuação com base técnica sólida. 
No quadro atual, a realidade aponta para o seguinte: a vigilância existe enquanto serviço - a vigilância atua sobre informações técnicas/diagnósticos fornecidos pelos regulados/fiscalizados - a vigilância, refém da situação, interpreta os dados de que dispõe - e com isso a vigilância corre sempre o risco de validar dados que ela não produziu e nem participou da produção. Supomos então, sempre, que todos os laudos de terceiros são verdadeiros - mas devemos ter em mente que muitos laudos ambientais são produzidos por empresas privadas. Os Laboratórios de Referência em Saúde Pública não cobrem o universo de agentes ambientais a serem analisados e medidos. O atual GAL (Gerenciador de Ambiente Laboratorial), sistema de informação que gerencia os dados dos laboratórios de saúde pública em âmbito nacional, informa no site do Ministério da Saúde, relativo ao módulo Ambiental e Saúde do Trabalhador, em produção, que este permitirá:

\begin{abstract}
Gerenciar a entrada e processamento de ensaios de água para consumo humano para monitoramento da rede estadual de abastecimento público. Prevista também a inclusão das amostras de ar e solo. Permitindo o controle desde o cadastramento das solicitações passando pelos processos de triagem, processamento, emissão de relatórios de ensaio, consultas até a emissão de relatórios de produção e gestão (Ministério da Saúde, 2018).
\end{abstract}

$\mathrm{Na}$ atual prática em uso desse sistema no Estado de São Paulo (a título de exemplo), os dados de qualidade da água para consumo humano produzidos pelo laboratório de referência (Instituto Adolfo Lutz) na rotina diária correspondem a apenas: cor, turbidez, pH, coliformes totais e Eschericia coli. Todos os outros quase 80 parâmetros exigidos pela legislação vigente são oriundos de laboratórios terceiros certificados e contratados pelas empresas reguladas, ou ainda produzidos pela própria empresa semestralmente.

Tal exemplo se sustenta na própria legislação sobre a qualidade da água para consumo humano, objeto fundamental da Vigilância Ambiental, a Portaria de Consolidação no 5 de 03 de outubro de 2017, no seu anexo XX, artigo 21ํㅡ, estabelece que:

Art. 21. As análises laboratoriais para controle e vigilância da qualidade da água para consumo humano podem ser realizadas em laboratório próprio, conveniado ou subcontratado, desde que se comprove a existência de sistema de gestão da qualidade, conforme os requisitos especificados na NBR ISO/IEC 17025:2005. (BRASIL, 2017) 
Rigorosamente, o que pode significar essa total confiança em laudos não produzidos no âmbito da Vigilância Ambiental? Uma consequência da efetivação do Estado mínimo. Na prática, é o mercado quem dá a informação que o Estado interpreta para proteger a população. A chave para a correta interpretação do risco está na informação produzida pelo mercado. A biopolítica que se dá no campo de atuação da Vigilância Ambiental está sob o controle do mercado.

Qual biopolítica? Aquela que valida a situação de saúde ambiental a que todos, com as devidas diferenças regionais, estão expostos. Com laudos ambientais apresentados por empresas do mercado, como produtos de negociação entre partes, o Estado, através da Vigilância Ambiental, avalia o risco e desenvolve ações de proteção e vigilância da saúde de populações.

Pressupomos, esperançosamente, que o capital tem interesses humanitários. Que está comprometido com a política de saúde do país. Esse mesmo capital, que com sua lógica de atuação, viabilizou a condição ambiental a que agora estamos submetidos, tal como já estudamos. Melhor ainda, o capital que trabalha para a privatização dos serviços de saúde.

Seria verdade que o capital nada tem a temer quanto à regulação ambiental?

Segundo Marques (2016), essa hipótese é ilusória. O capitalismo não pode ser sustentável por pelo menos três motivos: $\underline{\text { o primeiro }}$ - a economia não pode ser circular, mesmo com os esforços de ecoeficiência - o aumento por demanda e por recursos naturais tende a anular as conquistas por rendimento energético; $\underline{\text { o segundo }}$ - a escassez crescente de recursos naturais redunda em agravamento do impacto ambiental (lei da pirâmide de recursos de Heinberg); o terceiro - o custo ambiental não pode ser internalizado, o valor total gerado por uma atividade é, em geral, menor que o valor econômico do patrimônio da biosfera destruído para essa produção. 
Apoiados em Marques (2016) cabe perguntar quanto à relevância da saúde humana para esse sistema, que a transforma em produto. A doença, a prevenção, o tratamento são negócios. Criam demanda. Fazem parte do nosso biovalor, como nos lembrou Rose (2013).

Com a biopolítica instituída no momento, o mercado poderia ser fortemente prejudicado se problemas ambientais causadores de doenças e agravos fossem efetivamente atacados. Dispomos de soluções para as consequências, podemos prevenir e remediar com tecnologias biomoleculares avançadíssimas. Para sermos mais claros: a cura e a prevenção implicariam em menos lucros.

É nesse sentido que a Vigilância Ambiental, hoje, ocupa um terreno não totalmente seu, não totalmente do Estado. Ela foi fundada sob uma governamentalidade onde a proteção social é relevante, no SUS, mas atua em território neoliberal selvagem. $O$ que ela pretende prevenir, outros pretendem meramente remediar.

Os efeitos ambientais causados por substâncias tóxicas coincidem com as possibilidades de soluções biomédicas - falamos de teratogenicidade, genotoxicidade, carcinogenicidade - do biomolecular manipulável e passível de cálculos de risco. Seria possível, em virtude das tecnologias disponíveis, detectar uma epidemia de pré-enfermidade (ROSE, 2013).

Se por um lado o exposto acima é verdadeiro, não devemos negar que a estrutura mais simples oferecida pela Vigilância em Saúde Ambiental pode ter imenso potencial de auxílio e proteção, como um evento recente pode ilustrar.

Um desastre de magnitude incontestável ocorreu em Mariana (MG) após o rompimento de uma barragem da empresa Samarco, em 05 de novembro de 2015, lançando no meio ambiente mais de 34 milhões de metros cúbicos de lama oriunda da produção de minério de ferro. Até o momento foram registradas 17 mortes e mais de 660 famílias foram desabrigadas, cuja água para consumo humano foi suspensa por dias até liberação técnica. Esta já é considerada a maior tragédia ambiental do 
país. A lama avançou pelo sudeste e chegou a atingir o Estado do Espírito Santo. O site do governo federal informa que:

\begin{abstract}
...seiscentos e sessenta e três quilômetros de rios e córregos foram atingidos; 1.469 hectares de vegetação, comprometidos; 207 de 251 edificações acabaram soterradas apenas no distrito de Bento Rodrigues. Esses são apenas alguns números do impacto, ainda por ser calculado, do desastre, já considerado a maior catástrofe ambiental da história do país (GOVERNO DO BRASIL, 2017).
\end{abstract}

Porto (2016) analisou este acidente e acrescenta que na bacia do Rio Doce foram recolhidas 11 toneladas de peixes mortos, havendo ainda a possibilidade de extinção de 5 espécies. Relata que 1.430 hectares de terras nos municípios de Mariana, Barra longa e Rio Doce não podem mais ser utilizados para atividades agropecuárias (PORTO, 2016).

Neste caso, a Vigilância da qualidade da água para consumo humano com os parâmetros mais simples, como cor, turbidez, pH e coliformes totais; a vigilância de populações ribeirinhas que venham a ser expostas a solos contaminados - não apenas por meio de diagnósticos ambientais de terceiros, como vimos, mas diretamente pelos serviços de saúde a partir de efeitos esperados - bem como a disponibilização do suporte médico oferecido pelo VIGIDESASTRE em situações dessa natureza são ferramentas de vigilância e proteção preciosas. Isso porque neste tipo de situação não operamos em um nível sutil, subclínico por exemplo (não imediatamente): operamos com efeitos imediatos no ambiente e nas pessoas. Convém lembrar que em casos como esse, todas as vigilância entram em ação e o outro aspecto da saúde ambiental, hoje incorporado no aparato das doenças transmissíveis, ou seja os fatores biológicos, entra em plena ação.

Tal é momento paradoxal que a Vigilância em Saúde Ambiental vive. Importante para uma série de necessidades e impotente para tantas outras que estão em pleno andamento.

Dentre as razões desse contexto, não apenas da Vigilância Ambiental e outras Vigilâncias, mas do próprio Sistema Único de Saúde, está o problema do financiamento do Sistema, ou melhor dizendo, o subfinanciamento. Mendes (2012) 
esclarece este aspecto à luz da dinâmica do capital, em especial o capital portador de juros que esfola os cofres públicos para atendimento da dívida pública.

\begin{abstract}
É importante também que se diga que, especialmente desde 1995, o país tem passado por uma tensão no âmbito da execução das políticas sociais, com respeito à manutenção dos elevados superávits primários. No âmbito da previdência, da seguridade e da saúde, responsáveis por grandes despesas, a orientação dos governos tem sido a de reduzir os direitos, de forma a diminuir o peso do Estado na gestão da aposentadoria e nos cuidados com a saúde, e a assegurar o florescimento dos fundos de pensão e dos planos de saúde. Esse movimento que se desenvolve nesse período vem se tornando mais agudo a partir da crise de 2008 (MENDES, 2012 p.109).
\end{abstract}

As citações acima ilustram ainda mais a noção de Estado-corporação que mencionamos páginas atrás: denotam um Estado financeirizado e refém dos juros. Nossa proteção social é limitada porque:

O capital portador de juros impõe condicionantes de apropriação do fundo público de saúde; e, em momentos de crise do capital, essa situação é muito mais agravada. Ele é particular, porque a magnitude das tensões no "núcleo duro" do poder da política econômica impõe retrocessos, ao tornar frágil a possibilidade de construção de consenso na sociedade brasileira de que a saúde é um direito de todos e dever do Estado (MENDES, 2012 p.158).

A lógica econômica vem seguindo a todo vapor. Dennis Meadows, ao refletir sobre o relatório por ele liderado em 1972 denominado "The limits to growth", atualiza a seguinte conclusão:

Quando publicamos The limits of growth..., a população mundial era aproximadamente 3,65 bilhões. Agora ela chega a cerca de 6,5 bilhões. A produção industrial mais do que dobrou no período, assim como o uso de metais no mundo. Consequentemente, o nível de emissão de poluentes também cresce exponencialmente. Essas tendências ilustram o crescimento exponencial, em que em um curto período de tempo duplicaram-se as acumulações ocorridas em toda a história passada. O resultado é que já ultrapassamos os limites. Esse fato é evidenciado pelos dados sobre a pegada ecológica da humanidade, medida por Mathis Wackernagel. Ainda havia tempo para reduzir o passo. Agora o uso que a humanidade faz dos recursos está em cerca de $125 \%$ do nível sustentável a longo prazo (MEADOWS, 2010 p. 28).

Enquanto tecnologia de governo, a Vigilância Ambiental deve articular em torno de si um arcabouço de mecanismos para viabilizar seus objetivos. Ela deve conter a capacidade de articular diversas forças legais, profissionais, administrativas e judiciais 
dentro de um dado governo. A definição de governo de Miller e Rose (2012) contempla essa noção que parte de Foucault:

O governo é um campo de estratégias, técnicas e procedimentos através dos quais forças diferentes procuram tornar programas operáveis, e por meio dos quais uma multidão de conexões são estabilizadas entre as aspirações das autoridades e as atividades de indivíduos e grupos (MILLER \& ROSE, 2012 p.81-82).

Porém, tal campo de interações se apresenta hoje dentro do neoliberalismo, uma filosofia econômica que reativa princípios liberais, tais como: o ceticismo em relação a capacidade das autoridades políticas de governar; regular por princípios de mercado o bem-estar social; empreendedorismo econômico acima da regulação. Então "o empreendedorismo ativo deve suplantar a passividade e a dependência da solidariedade responsável à medida que os indivíduos são encorajados a lutar para otimizar sua própria qualidade de vida e a de suas famílias" (MILLER \& ROSE, 2012).

O clima político, em termos de governamentalidade, é, como dissemos, desfavorável para o amplo desdobramento das funções esperadas da Vigilância Ambiental. Biopolíticamente, o fazer viver se dá no estímulo à medicina tecnológica individual e o deixar morrer corre por conta da baixa ênfase aos diagnósticos ambientais relativos aos passivos e às variadas exposições às substâncias tóxicas que ocorrem largamente. 


\section{Capítulo 7}

\section{Conclusão e avaliação do caminho percorrido}

O processo histórico que culminou no surgimento da Vigilância Ambiental foi complexo, traçado por uma rede de interações entre acontecimentos importantes. É interessante perceber que, se por um lado, o ambiente é um aspecto chave na compreensão da etiologia de doenças e agravos, por outro, apenas tardiamente ele retorna à pauta com destaque - e apenas após uma sequência de ocorrências que transformaram a realidade ambiental.

A demanda ambiental renasceu. Tal percepção chama a atenção por se tratar, historicamente, de um meio ambiente "novo": contaminado, degradado, secundarizado. Tudo isso apesar da conclusão ecológica elementar de que é dele que surge a vida, é nele que ocorre a vida e é nele que se conclui a vida. A modernidade ignorou essa dependência essencial. Aliás, ela assume o movimento de gerenciar essa dependência essencial como foi demonstrado na biopolítica. Ao assumir essa postura se dá o encontro com o paradoxo da sociedade de risco de Beck (2011): produção de bens e tecnologias e produção de riscos.

As rotas de exposição, os mecanismos de transporte de poluentes, a evolução das espécies em nível microbiológico são de naturezas tão diversas e de difícil previsibilidade - seja no ambiente onde os compartimentos ambientais estão em contato mais direto, seja em ambientes onde diversas novas camadas se interpõem, em especial no ambiente urbano - que a pretensão de colonizar o futuro é ilusória. Nos tempos da sociedade de risco o volume de interações ambientais é imenso e isso implica no desafio do controle, do monitoramento e da mitigação de riscos ambientais, entre outros.

Não foi por acaso que a agenda ambiental se tornou tão complexa. Foi demonstrado que os eventos ambientais estão diretamente relacionados às interações entre técnica e meio ambiente - e discutimos como essa relação tem se dado de maneira negativa ao longo das últimas décadas. Identificamos etapas que se 
coadunam com a demanda tecnológica da saúde pública no país em cada momento histórico que refletia essa interação.

Para fins de conclusão, com a devida ressalva, um apontamento importante é a dependência essencial mencionada há pouco. O fenômeno vida é anterior a qualquer governamentalidade socialmente construída e é de natureza emergente. $O$ significado prático dessa afirmação culmina em uma noção que transcende ao histórico e ao cultural: o ambiente é capaz de provocar e/ou induzir processos no fenômeno vida, interferindo vertical e horizontalmente na dimensão social. Uma vez afetada, a vida se impõe, é soberana e determinante sobre qualquer construção social.

A Vigilância Ambiental, enquanto movimento de política pública, desperta tardiamente. Trata-se de um despertar necessário, impositivo. Pode parecer estranho utilizar o termo "despertar", mas ele se mostra pertinente ao considerarmos que a Vigilância Ambiental estava implícita todo o tempo nas Vigilâncias Epidemiológica e Sanitária; ela se apropriou do cabedal dessas áreas para se estruturar e é sobre as suas técnicas que ela se fundamenta.

Há que se ponderar ainda sobre o caráter questionador que a Vigilância Ambiental carrega. Todo alerta, todo diagnóstico, toda intervenção que vier a ser feita estará impregnada de questionamentos sobre as forças motrizes - para nos apropriarmos do jargão da escola canadense citado acima - em movimento na atualidade. A operacionalização da economia política molda as práticas sociais e tecnológicas que produzem resultados/consequências no meio ambiente. A saber, a contaminação da água, do solo, do ar e dos organismos é um fruto da árvore da governamentalidade em ação.

Se considerarmos o cenário ambiental exposto, podemos inferir quanto à secundarização da sustentabilidade ecológica. Não dos recursos naturais, que estão em plena utilização e consumo, mas da necessidade de gerenciar o uso dos recursos de modo a permitir que o natural seja recomposto, princípio básico da noção de desenvolvimento sustentável. 
Que dizer então sobre as demais formas de vida? O ritmo da extinção de espécies é alto. Em 02 de março de 2018, o site da Organização das Nações Unidas Brasil destacava exatamente essa notícia: "biodiversidade desaparece à velocidade mil vezes mais rápida por causa do homem, alerta ONU". Especificamente nessa matéria, foi dado um alerta sobre a redução de 100.000 para 4.000 do número de grandes felinos na Ásia em um período de 100 anos (ONU, 2018). Afirmações dessa natureza denunciam a baixa prioridade de uma abordagem preservacionista ou conservacionista na agenda global. São esperadas mais consequências derivadas do equilíbrio ecológico que vai se quebrando.

Se houve um mito que pregou a evolução contínua do progresso científico com a concomitante solução de arestas tecnológicas, no presente a ideia de modelagem ambiental pode nos levar à situações problemas novamente. A transformação da modelagem ambiental em produto/solução para empresas que têm de lidar com processos de remediação impostos pela legislação vigente pode desembocar em uma região nebulosa, disfarçada com um discurso técnico-matemático supostamente exato. O uso dessas tecnologias, sem dúvida úteis, podem ocultar problemas importantes em função da modelagem adotada. Comentar essa possibilidade aqui se faz necessária ao considerarmos que a modelagem ambiental é muito utilizada no diagnóstico de áreas contaminadas, por exemplo.

No ambiente de governamentalidade que foi se desenhando durante a história conseguimos observar a imposição da agenda ambiental. O ambiente técnico, na medida em que foi se encontrando e interferindo no ciclos ecológicos que estavam em andamento, provocou efeitos que não puderam ser calados nem explicados por outras alternativas em andamento. Foi assim que acidentes ampliados e diversos eventos de intoxicações fortaleceram e demandaram campanhas de natureza ambiental e de saúde.

Com isso, no momento em que o Sistema Único de Saúde, no Brasil, estabelece que a saúde é um direito universal e gratuito e colocou, no texto jurídico, o meio ambiente como um determinante de saúde, a temática da saúde ambiental se impôs enquanto componente fundamental frente à integralidade do cuidado. 
A partir do momento em que a vigilância da saúde (hoje institucionalizada como Vigilância em Saúde) emerge como estratégia de ação e modelo assistencial, enquanto serviço de saúde, a saúde ambiental passou a integrar formalmente as discussões acadêmicas e, mais tarde, foi demandada como área de atuação e proteção da saúde - mais explicitamente como Vigilância Ambiental em Saúde e mais tarde, como demonstramos, como Vigilância em Saúde Ambiental, ou apenas Vigilância Ambiental.

Feito o elementar, que é a criação da área, andam os processos de definição de escopos, de encontros e desencontros com outros serviços e órgãos públicos, de financiamento e criação de um corpo técnico qualificado para o propósito, de produção de um arsenal legal apropriado para as ações necessárias, de visibilidade frente às outras políticas públicas relacionadas, de crescimento de produção acadêmica tanto no campo teórico como no prático. Numa palavra: de desenvolvimento, maturação e estabelecimento da área.

Cabe aqui ressaltar que, com exceção da legislação da qualidade da água para consumo humano, a Vigilância Ambiental atua com base em parâmetros de outros órgãos ambientais para qualificar situações de risco à saúde humana. $\mathrm{O}$ conflito de competências reduz a potência da ação de saúde, fazendo com que a autoridade sanitária deva aguardar pareceres técnicos que não são produzidos pela área da saúde, mas pela área ambiental, e a partir daí fundamentar tecnicamente cenários de riscos presentes, passados ou futuros.

Em um ambiente biopolítico cada vez mais desafiador, a Vigilância Ambiental gravita entre sistemas contraditórios, a saber: o SUS e o mercado. Vítima de uma hipocrisia política em termos de implantação e investimento, tem toda a responsabilidade e poucos recursos; atua sequestrada pelo discurso que a fez existir e pela inação política que a faz viver um quadro crônico de inanição. Ainda assim, como vimos, sua necessidade brota do próprio solo neoliberal. 
Acreditamos que, após esse trajeto, ousar estabelecer uma proposta de definição de Vigilância Ambiental seja aceitável. Ponderando sobre tudo o que observamos e discutimos ao longo da tese, diríamos que:

\begin{abstract}
A Vigilância Ambiental é a área do Sistema Único de Saúde que assume integralmente o meio ambiente como determinante de saúde. Promove ações de fiscalização, atendimento e acompanhamento de denúncias, investigação epidemiológica, educação em saúde, utiliza o poder de polícia para intervir em casos de risco eminente e produz informação com fins de vigilância da saúde (considere a diferença para a vigilância em saúde que apontamos acima). Todo movimento da Vigilância Ambiental tem como finalidade uma ação de prevenção e proteção à saúde.
\end{abstract}

Não estamos diante de uma área pronta. Além da construção em andamento já destacada, a abertura é necessária para que oportunidades de vigilância da saúde a partir de estratégias novas possam ser incorporadas. Toda rigidez pode nos remeter à apenas situações de mitigação e não de antecipação de eventos críticos, ou mesmo a detecção de processos já em andamento. A conexão da inteligência que rege a vigilância da saúde com a de áreas de cunho ecológico, com foco em outros seres vivos, pode nos ser de grande valia, como a própria área de controle de zoonoses nos demonstra.

Na era da informação, devemos ser capazes de aproveitar a alta conectividade técnico-cientifica-informacional, estabelecida e em desenvolvimento constante, para auxiliar na produção de diagnósticos ambientais mais eficazes. Ao mesmo tempo, o uso da tecnologia não deve substituir a análise de cenário que ocorre em campo e interage com dimensões do espaço que os sistemas de informação não captam, como por exemplo o social e o cultural.

É o que se pretende garantir com conceitos tornados explícitos no documento que define a Política Nacional de Vigilância em Saúde (2018). Não escapam de definições claras as noções de território, risco e vulnerabilidade - conceitos operacionalizáveis apenas no território vivo. 
O paradoxo mais interessante a ser notado e observado nos próximos anos diz respeito ao quanto a vigilância será mesmo capaz de fazer vigilância, em que pese um dos mais potentes de todos os determinantes da saúde: a economia política em vigor, que pretende fazer com que o mercado regule a vida daqueles que têm pouca ou nenhuma voz.

Tal é genealogia crítica que foi construída com as chaves da biopolítica e da governamentalidade, ainda em pleno andamento. 


\section{Referências Bibliográficas}

ABRASCO. Associação Brasileira de Saúde Coletiva. Dossiê ABRASCO: um alerta sobre os impactos dos agrotóxicos na saúde. Rio de Janeiro, EPSJV; São Paulo: Expressão Popular, 2015.

ACSELRAD, H.; MELLO, C. C. A.; BEZERRA, G. N. O que é Justiça Ambiental. Rio de Janeiro: Garamond, 2009.

ALVAREZ, I. A. P. Nos meandros da planície: industrialização e meio ambiente em Cubatão. In MARTINEZ, P. H. (ORG) História Ambiental Paulista: temas, fontes e métodos. São Paulo: Editora Senac São Paulo, 2007

ARAÚJO, M. C. Industrialização Brasileira no Século XX. Osasco: Edifieo, 2008.

AUGUSTO, L. G. S. Saúde e Vigilância Ambiental: um tema em construção. Epidemiologia e Serviços de Saúde. Brasília: v.12, n. 4, p. 77-187, out/dez 2003.

BARCELLOS, C.; QUITÉRIO, L. A. D. Vigilância ambiental em saúde e sua implantação no Sistema Único de Saúde. Rev. Saúde Pública, São Paulo, v. 40, n. 1, p. 170-177, Fev. 2006.

BECK, U. Sociedade de Risco: rumo a uma outra modernidade. São Paulo: Editora 34, 2011.

BENCHIMOL, J. L. Febre amarela e a Instituição da Microbiologia no Brasil. In HOCHMAN, G. \& ARMUS, D. (ORG.) Cuidar, controlar, curar: ensaios históricos sobre saúde e doença na América Latina e Caribe. Rio de Janeiro: Editora Fiocruz, 2004.

BOULOS, G. Por que ocupamos? Uma introdução à luta dos sem-teto. São Paulo: Autonomia Literária, 2015.

BRASIL. Ministério da Saúde. Secretaria de Vigilância em Saúde. Departamento de Vigilância em Saúde Ambiental e Saúde do Trabalhador. Resumo executivo da Conferência Nacional de Saúde Ambiental: saúde e ambiente, vamos cuidar da gente. Distrito Federal: Ministério da Saúde; 2010.

BRASIL. Política Nacional de Vigilância em Saúde. Documento base. GT PNVS. Documento elaborado pelo GT instituído pela Portaria SVS no 14 , de 22/08/2014. Disponível em: http://portalms.saude.gov.br/vigilancia-emsaude/conferencia-nacional-de-vigilancia-em-saude, acessado em 09.07.2018.

BRASIL. Conselho Nacional de Saúde. Política Nacional de Vigilância em Saúde. Resolução ํㅜ588, de 12 de julho de 2018. 
BRASIL. Ministério da Saúde. Portaria 1823, de 23 de agosto de 2012. Institui a Política Nacional da Saúde do Trabalhador e da Trabalhadora. Distrito Federal, 2012.

BRASIL. Ministério da Saúde. Conselho Nacional de Saúde. Subsídios para construção da Política Nacional de Saúde Ambiental. Brasília: Editora do Ministério da Saúde, 2009.

BRASIL. Lei n. 8.080, de 19 de setembro de 1990. Dispõe sobre as condições para a promoção, proteção e recuperação da saúde, a organização e o funcionamento dos serviços correspondentes, e dá outras providências. Diário Oficial da União, Brasília, DF, 20 set.1990, p. 18055.

BRASIL. Lei 12.864, de 24 de setembro de 2013. Altera o caput do artigo $3^{\circ}$ da Lei $\mathrm{n}^{\circ}$ 8.080, de 19 de setembro de 1990, incluindo a atividade física como fator determinante e condicionante da saúde. Diário Oficial da União, Brasília, DF. Disponível em: http://www.planalto.gov.br/ccivil 03/ ato20112014/2013/lei//12864.htm, acessado em 02.10.2017.

BRASIL. Portaria Interministerial MTE/MS/MPS no 9, de 07 de outubro de 2014. Publica a Lista Nacional de Agentes Cancerígenos para Humanos (LINACH), como referência para formulação de políticas públicas, na forma do anexo a esta Portaria. Diário Oficial da União, Brasília, DF, 08 out. 2014, p. 140 142.

BRASIL. Portaria no 3.252, de 22 de dezembro de 2009. Aprova as diretrizes para execução e financiamento das ações de Vigilância em Saúde pela União, Estados, Distrito Federal e Municípios e dá outras providências. Diário Oficial da União, Brasília, DF, 23 dez. 2009, p. 65-69.

BRASIL. Portaria no 1378, de 09 de julho de 2013. Regulamenta as responsabilidades e define diretrizes para execução e financiamento das ações de Vigilância em Saúde pela União, Estados, Distrito Federal e Municípios, relativos ao Sistema Nacional de Vigilância em Saúde e Sistema Nacional de Vigilância Sanitária. Diário Oficial da União. Brasília, DF, 10 jul. 2013, p. 48-50.

BRASIL. Portaria de Consolidação no 5, de 28 de setembro de 2017. Anexo XX. Do controle e da vigilância da qualidade da água para consumo humano e seu padrão de potabilidade (Origem: PRT MS/GM 2914/2011). Diário Oficial da União. Brasília, DF, n. 190, 03 out. 2017.

BREILH, J. La determinación social de la salud como herramienta de transformación hacia una nueva salud pública (salud coletiva). Rev Fac Nac Salud Pública v. 31, (supl 1), p. 13-27, 2013.

CÂMARA, J. B. D. Governança Ambiental no Brasil: ecos do passado. Revista de Sociologia e Política: v. 21, n. 46, p. 125-146 jun. 2013. 
CÂMARA, V. M.; TAMBELLINI, A. T. Considerações sobre o uso da epidemiologia nos estudos de Saúde Ambiental. Revista Brasileira de Epidemiologia. São Paulo: v. 6, n. 2, p. 95-104, jun. 2003.

CAPONI, S. Viver e deixar morrer: biopolítica, riscos e gestão das desigualdades. Revista Redbioética. UNESCO: v.2, n.5, p. 27-37, dez. 2014.

CASTRO, E. Introdução a Foucault. Belo Horizonte: Editora Autêntica, 2014.

CETESB. Companhia de Tecnologia e Saneamento Ambiental do Estado de São Paulo. Análise de Risco Tecnológico. Grandes Acidentes. Disponível em: $\quad$ http://cetesb.sp.gov.br/analise-risco-tecnologico/grandesacidentes/flixborough/, acessado em 05 de outubro de 2017.

CETESB. Companhia de Tecnologia e Saneamento Ambiental do Estado de São Paulo. Texto Explicativo. Relação de Áreas Contaminadas e Reabilitadas no Estado de São Paulo. Disponível em: http://cetesb.sp.gov.br/areascontaminadas/wp-content/uploads/sites/17/2013/11/Texto-explicativo2016.pdf, acessado em 18 de janeiro de 2018.

CONFEDERAÇÃO NACIONAL DA INDÚSTRIA (CNI). Portal da Indústria. Estatísticas Industriais. Disponível em: http://perfilestados.portaldaindustria.com.br/comparativo estados/populares, acessado em 03.10.2017.

COSTA. N. R. Lutas urbanas e controle sanitário: Origens das políticas de saúde no Brasil. Rio de Janeiro: Vozes/ABRASCO, 1985.

COSTA, E. A.; ROZENFELD, S. Constituição da Vigilância Sanitária no Brasil. In Fundamentos de Vigilância Sanitária. ROZENFELD. S. (ORG). Rio de Janeiro: Editora Fiocruz, 2000.

CVE. Centro de Vigilância Epidemiológica "Prof. Alexandre Vranjac". Doenças Ocasionadas pelo Meio Ambiente. Disponível em: http://www.saude.sp.gov.br/cve-centro-de-vigilancia-epidemiologica-prof.alexandre-vranjac/areas-de-vigilancia/doencas-ocasionadas-pelo-meioambiente/, acessado em 26.12.2018.

CVS. Centro de Vigilância Sanitária do Estado de São Paulo. Meio Ambiente. Disponível em: http://www.cvs.saude.sp.gov.br/area.asp?at codigo=3, acessado em 26.12.2018.

CZERESNIA, D., MACIEL, E. M. G. S., Oviedo, RAM. Os sentidos da saúde e da doença. Rio de Janeiro: Editora Fiocruz; 2013.

DAPPER, S. N.; SPORH, C.; ZANINI, R.R. Poluição do ar como fator de risco para a saúde: uma revisão sistemática no Estado de São Paulo. Estud. Av., São Paulo, v. 30, n. 86, p. 83-97, Apr. 2016. 
DATASUS. BRASIL. Departamento de Informática do SUS. Disponível em: http://datasus.saude.gov.br/datasus, acessado em 12.10.2017.

DUPUY, J. P. The catastrophe of Chernobyl twenty years later. Estud. av. São Paulo, v. 21, n. 59, p. 243-252, Apr. 2007.

FOUCAULT, M. Microfísica do poder. 3ª Ed. São Paulo: Paz e Terra, 2015a.

FOUCAULT, M. História da Sexualidade I: a vontade de saber. São Paulo: Paz e Terra, 2015b.

FOUCAULT. M. Nascimento da Biopolítica. São Paulo: Martins Fontes, 2008a.

FOUCAULT. M. Em Defesa da Sociedade. São Paulo: Martins Fontes, 2016.

FOUCAULT. M. Segurança, território, população. São Paulo: Martins Fontes, 2008c.

FREITAS, C. M.; PORTO, M. F. S.; GOMEZ, C. M. Acidentes químicos ampliados: um desafio para a saúde pública. Rev. Saúde Pública, São Paulo, v. 29, n. 6, p. 503-514, dez. 1995.

FUNASA. BRASIL. Vigilância Ambiental em Saúde. Fundação Nacional de Saúde. Brasília: FUNASA, 2002a.

FUNASA. BRASIL. Textos de Epidemiologia para Vigilância Ambiental em Saúde. Brasília: FUNASA, 2002b.

FURTADO, M.; SZAPIRO, A. Promoção de Saúde e seu alcance biopolítico: o discurso sanitário da sociedade contemporânea. Saúde Soc. São Paulo, v. 21, n. 4 , p. $811-821,2012$.

GONÇALVES, C. W. P. Os (des)caminhos do meio ambiente. São Paulo: Contexto, 2001.

GOUVEIA, R.; PALMA, J. J. SUS: na contramão do neoliberalismo e da exclusão social. Estud. Av., São Paulo, v. 13, n. 35, p. 139-146, Apr. 1999 .

GOVERNO DO BRASIL. Entenda o acidente de Mariana e suas consequências para 0 meio ambiente. Disponível em: http://www.brasil.gov.br/meio-ambiente/2015/12/entenda-o-acidente-demariana-e-suas-consequencias-para-o-meio-ambiente, acessado em 09.10 .2017$.

GOVERNO DE GOIÁS. SECRETARIA DE ESTADO DA SAÚDE. Césio 137. Disponível em: http://www.cesio137goiania.go.gov.br/, acessado em 09.10.2017. 
GUIDDENS, A. As consequências da modernidade. São Paulo: Editora UNESP, 1991.

HOCHMAN, G. A era do saneamento. São Paulo: Hucitec, 2012.

HOCHMAN, G.; LIMA, N. T. "Pouca saúde e muita saúva": sanitarismo, interpretações do país e ciências sociais. In HOCHMAN, G. \& ARMUS, D. (ORG.) Cuidar, controlar, curar: ensaios históricos sobre saúde e doença na América Latina e Caribe. Rio de Janeiro: Editora Fiocruz, 2004.

JACOBI, P. Movimentos Sociais e Políticas Públicas. São Paulo: Cortez, 1989.

KORMONDY, E. J.; BROWN, D. E. Ecologia Humana. São Paulo: Atheneu Editora, 2002.

KÓS, M.I. et al. Efeitos da exposição a agrotóxicos sobre o sistema auditivo periférico e central: uma revisão sistemática. Cad. Saúde Pública, Rio de Janeiro, 29 (8):1491-1506, ago, 2013.

LEONARD, A. A História das Coisas: da natureza ao lixo, o que acontece com tudo que consumimos. Rio de Janeiro: Zahar, 2011.

LOPES, N.; NOZAWA, C.; LINHARES, R. E. C. Características gerais e epidemiologia dos arbovírus emergentes no Brasil. Rev. Pan-Amaz Saude. Ananindeua, v. 5, n. 3, p. 55-64, set, 2014.

LUIZ, O. C.; COHN, A. Sociedade de risco e risco epidemiológico. Cad Saúde Pública, V.11, n. 22, p. 2339-2348, 2006.

MACIEL FILHO, A., A. et al. Indicadores de Vigilância Ambiental em Saúde. Inf. Epidemiol. Sus, Brasília, v. 8, n. 3, p. 59-66, set. 1999.

MACHADO, J. M. H. et al. Vigilância em Saúde Ambiental e do Trabalhador: reflexões e perspectivas. Cad. Saúde Colet. V. 19, n. 4, p. 399-406, Rio de Janeiro, 2011.

MANSANO, S. R. V.; NALLI, M. SUSTENTABILIDADE E BIOPOLÍTICA: UM PROBLEMA PARA A CONTEMPORANEIDADE. Psicol. Soc., Belo Horizonte, v. 29, e156315, 2017.

MARQUES, L. Capitalismo e Colapso Ambiental. Campinas, SP: Editora Unicamp, 2016.

MARQUES, M.C.C. et al. A importância da perspectiva histórica para o pensamento social em saúde: a contribuição de Madel Luz e Emerson Merhy. Hist. cienc. saude-Manguinhos, Rio de Janeiro, v. 25, n. 2, p. 353369, jun. 2018. 
MARTINS, A. Filosofia e Saúde: métodos genealógicos e filosóficoconceitual. Cad. Saúde Pública, Rio de Janeiro, v. 20, n. 4, p. 950-958, ago. 2004.

MEADOWS, D. Como e quando conheceremos os limites para o crescimento? In: BINDÉ, J. Fazendo as pazes com a Terra: Qual o futuro da espécie humana no planeta? Brasília: UNESCO, Editora Paulus, 2010.

MEADOWS, D. Et al. The limits to growth: a report for the Club of Rome's Projeto on the predicament of makind. New York, United States: Universe Books, 1972.

MENDES. A. N. Tempos turbulentos na saúde pública brasileira: impasses do financiamento no capitalismo financeirizado. São Paulo: Hucitec, 2012.

MILLER, P.; ROSE, N. Governando o presente: gerenciamento da vida econômica, social e pessoal. São Paulo: Paulus, 2012.

MINAYO. M.C. S. O Desafio do Conhecimento: a pesquisa qualitativa em saúde. São Paulo: Hucitec, 2014.

MINISTÉRIO DO MEIO AMBIENTE. BRASIL. Segurança Química. Disponível em: http://www.mma.gov.br/seguranca-quimica, acessado em 05.10.2017.

MINISTÉRIO DA SAÚDE. SECRETARIA DE VIGILÂNCIA EM SAÚDE. Guia de Vigilância em Saúde. Brasília: Ministério da Saúde, 2014.

MINISTÉRIO DA SAÚDE. BRASIL. Vigilância Ambiental. Disponível em: http://portalsaude.saude.gov.br/index.php/oministerio/principal/secretarias/svs/ vigilancia-ambiental, acessado em 12.10.2017.

MINISTÉRIO DA SAÚDE. BRASIL. Febre Amarela. Disponível em: http://portalms.saude.gov.br/saude-de-a-z/febre-amarela, acessado em 17.01.2018.

MINISTÉRIO DA SAÚDE. BRASIL. Gerenciador de Ambiente Laboratorial; Disponível em: http://gal.datasus.gov.br/GALL/index.php?area=02, acessado em 07.09.2018.

MONTAGNER, C. C.; VIDAL, C.; ACAYABA, R. D. Contaminantes emergentes em matrizes aquáticas no Brasil: cenário atual e aspectos analíticos, ecotoxicológicos e regulatórios. Quim. Nova, Vol. 40, No. 9, 1094-1110, 2017.

NESPOLI, G. Biopolíticas da participação na saúde: o SUS e o governo das populações. In: GUIZARDI, F (ORG.) Políticas de participação e saúde. Rio de Janeiro: EPSJV; Recife: Editora Universitária - UFPE, 2014.

NEVES, C. A; B.; MASSARO, A. Biopolítica, produção de saúde e um outro humanismo. Interface (Botucatu), Botucatu, v. 13, supl. 1, p. 503-514, 2009. 
OLIVEIRA. A. 'Desenvolvimentismo' Brasileiro: um obstáculo ao pluralismo. In: Cidades, indústrias e os impactos do desenvolvimento brasileiro - Cadernos de Debates 3. Rio de Janeiro: FASE - Solidariedade e Educação, 2015.

ORTEGA, F. Biopolíticas da saúde: reflexões a partir de Michel Foucault, Agnes Heller e Hannah Arendt. Interface (Botucatu), Botucatu, v. 8, n. 14, p. 9-20, Feb. 2004.

PAIVA, O. C.; MOURA, S. Hospedaria de Imigrantes de São Paulo. São Paulo: Paz e Terra, 2008.

PATY, M. Inteligibilidade racional e historicidade. Estud. av., São Paulo, v. 19, n. 54, p. 369-390, ago. 2005.

PEIXOTO. D. R. G. Reflexões sobre alguns dos meios propostos por mais conducentes para melhorar o clima da cidade do Rio de Janeiro. In: Prefeitura da Cidade do Rio de Janeiro. A saúde pública no Rio de Dom João. Rio de Janeiro: Editora Senac Rio, 2008.

POGREBINSCHI, T. Foucault, para além do poder disciplinar e do biopoder. Lua Nova, São Paulo, n. 63, p. 179-201, 2004.

PONTELLI, R. C. N.; NUNES, A. A.; OLIVEIRA, S. V. W. B. Impacto na saúde humana de disruptores endócrinos presentes em corpos hídricos: existe associação com a obesidade? Ciênc. Saúde coletiva, Rio de Janeiro, v. 21, n. 3, p. 753-766, mar. 2016.

PORTO, M. F. S. A tragédia da mineração e do desenvolvimento no Brasil: desafios para a saúde coletiva. Cad. Saúde Pública, Rio de Janeiro, v.32, n.2, e00211015, fev. 2016.

PRADO JUNIOR, C. História Econômica do Brasil. São Paulo: Editora Brasiliense, 1977.

QUANDT, F. L. et al. Saúde Ambiental e atenção à saúde: construção e ressignificação de referências. Cad. Saúde Colet., Rio de Janeiro, v. 22, n. 2, p. 150-157, 2014.

RIBEIRO, H. Saúde Pública e Meio Ambiente: evolução do conhecimento e da prática, alguns aspectos éticos. Saúde e Sociedade, v.13, n.1, p. 7080, abr. 2004.

RIBEIRO, H. Desafios da Saúde Ambiental global. In: FORTES, P.A.C.; RIBEIRO, H. (ORGS). Saúde Global. Barueri, SP: Manole, 2014.

ROCHA, A. A.; PEREIRA, D. N.; PADUA, H. B. Produtos de pesca e contaminantes químicos na água da Represa Billings, São Paulo (Brasil). Rev. Saúde Pública, São Paulo, v. 19, n. 5, p. 401-410, out. 1985. 
RIGOTTO, R. M.; AUGUSTO, L. G. S. Saúde e ambiente no Brasil: desenvolvimento, território e iniquidade social. Cad. Saúde Pública, Rio de Janeiro, v. 23, supl. 4, p. 475-485, 2007.

RODRIGUES, M. O Antropoceno em disputa. Cienc. Cult., São Paulo, v. 69, n. 1, p. 19-22, mar. 2017.

RODRIGUES, et. al. Aplicabilidade do Sistema de Informação de Vigilância em Saúde de Populações Expostas a Solo Contaminado - SISSOLO. Cad. Saúde Colet., v. 19, n. 4, p. 411-416. Rio de Janeiro, 2011.

RHOLFS, D. B., et al. A Construção da Vigilância em Saúde Ambiental no Brasil. Cad. Saúde Colet., v. 19, n. 4, p. 391-394. Rio de Janeiro, 2011.

ROSE, N. A Política da própria Vida: biomedicina, poder e subjetividade no século XXI. São Paulo: Paulus, 2013.

SÁ-SILVA, J. R.; ALMEIDA, C. D.; GUINDANE, J. F. Pesquisa Documental: pistas teóricas e metodológicas. Revista Brasileira de História \& Ciências Sociais. Ano I, número I, julho de 2009.

SANTOS, M. A urbanização Brasileira. São Paulo: Edusp, 2013.

SECRETARIA DE VIGILÂNCIA EM SAÚDE. VIGIFIS. Disponível em http://portalsaude.saude.gov.br/index.php/oministerio/principal/secretarias/svs/ vigifis, acessado em 12.10.2017.

SEVERINO, A. J. Metodologia do Trabalho Científico. São Paulo: Cortez, 2007.

SILVA, M. V. Reflexões Sobre Alguns dos Meios Propostos Por Mais Conducentes para Melhorar o Clima da Cidade do Rio de Janeiro. In: Prefeitura da Cidade do Rio de Janeiro. A saúde pública no Rio de Dom João. Rio de Janeiro: Editora Senac Rio, 2008.

SOUZA, A. M. A. F. Vigilância Sanitária na Saúde Pública Brasileira e sua aproximação com o caso mexicano: Proteger, Vigiar e Regular. [tese]. São Paulo: Universidade de São Paulo, 2007

STEPAN, N. Eugenia no Brasil, 1917 - 1940. In HOCHMAN, G. \& ARMUS, D. (ORG.) Cuidar, controlar, curar: ensaios históricos sobre saúde e doença na América Latina e Caribe. Rio de Janeiro: Editora Fiocruz, 2004.

TAMBELLINI, A. T.; CÂMARA, V. M. A temática saúde e ambiente no processo de desenvolvimento do campo da saúde coletiva: aspectos históricos, conceituais e metodológicos. Ciênc. saúde coletiva, Rio de Janeiro, v.3, n. 2, p. 47-59,1998. 
TEIXEIRA, C. F.; PAIM, J. S.; VILASBOAS, A. L. SUS, modelos assistenciais e vigilância da saúde. Inf. Epidemiol. Sus, Brasília, v. 7, n. 2, p. 7-28, jun. 1998.

VERMELHO, L. L.; MONTEIRO, M. F. G. Transição demográfica e epidemiológica. In: MEDRONHO, R. A. (ORG.) Epidemiologia. São Paulo: Editora Atheneu, 2006.

VILLARDI, J. W. R. A Vigilância em Saúde Ambiental no Brasil - Uma reflexão sobre seu modelo de atuação: necessidades e perspectivas. [tese]. Rio de Janeiro: Escola Nacional de Saúde Pública Sérgio Arouca, 2015.

WALDMAN, E. A. Vigilância Epidemiológica como prática de saúde pública. [tese]. São Paulo: Faculdade de Saúde Pública da Universidade de São Paulo, 1991.

WORLD WATER FORUM. 8 ${ }^{\circ}$ Fórum Mundial da Água. Disponível em: http://www.worldwaterforum8.org/, acessado em 18 de janeiro de 2018. 
Anexos

Currículo Lattes 


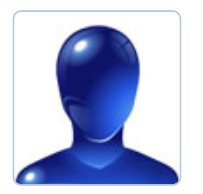

\section{Rodrigo Romão}

Endereço para acessar este CV:http://lattes.cnpq.br/0490973175952506

Última atualização do currículo em 21/11/2018

Resumo informado pelo autor

Mestre em Ciências pela Faculdade de Medicina da USP (Programa de Fisiopatologia Experimental), especialista em Gestão de Serviços Públicos de Saúde pela UNIFESP, possui graduação em Licenciatura Plena em Química pelo Centro Universitário Fundação Santo André (2001). Atua no Departamento de Vigilância à Saúde de Santo André atualmente como Gestor no CEREST (Centro de Referência em Saúde do Trabalhado) . É Professor de Gestão de Risco, Políticas Públicas de Saúde, Gestão de Resíduos de Serviços de Saúde e Vigilância em Saúde na Faculdade de Medicina do ABC. Doutorando em Saúde Pública na Faculdade de Saúde Pública da USP.

(Texto informado pelo autor)

Links para Outras Bases:

SciELO - Artigos em texto completo Scipi.

Nome civil

Nome Rodrigo Romão

\section{Dados pessoais}

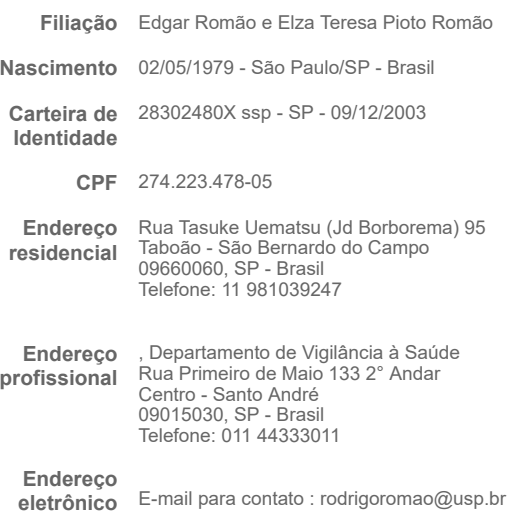

Formação acadêmica/titulação

2015 Doutorado em Programa de Saúde Pública.

Faculdade de Saúde Pública da USP, FSP-USP, Brasi

Orientador: Maria Cristina da Costa Marques

2007 - 2010 Mestrado em Ciências.

Faculdade de Medicina da Universidade de Sao Paulo, FMUSP, Bras

Título: Relação entre o baixo peso ao nascer e a poluição do ar no município de Santo André,SP, Ano de

obtenção: 2010

Orientador: Luiz Alberto Amador Pereira (6)

Especialização interrompido(a) em Gestão em Controles Ambientais. Faculdade de Tecnologia Ambiental SENAI Mario Amato, FTA SENAI MARIO, Brasil Ano de interrupção: 2014

2010 - 2012 Especialização em GESTÃO EM SERVIÇOS DE SAÚDE.

作

Título: PLANO DE GERENCIAMENTO DE RESÍDUOS DE SERVIÇOS DE SAÚDE

1998 - 2001 Graduação em Licenciatura Plena em Quimica.

Centro Universitário Fundação Santo André, CUFSA, Santo Andre, Brasi

Formação complementar

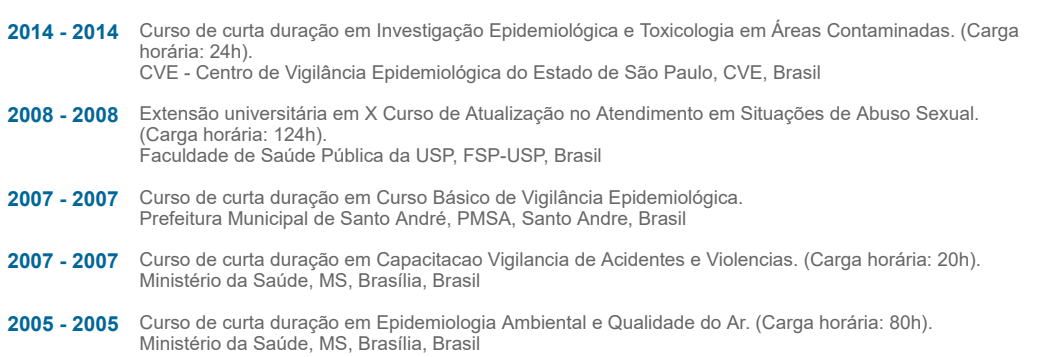

